
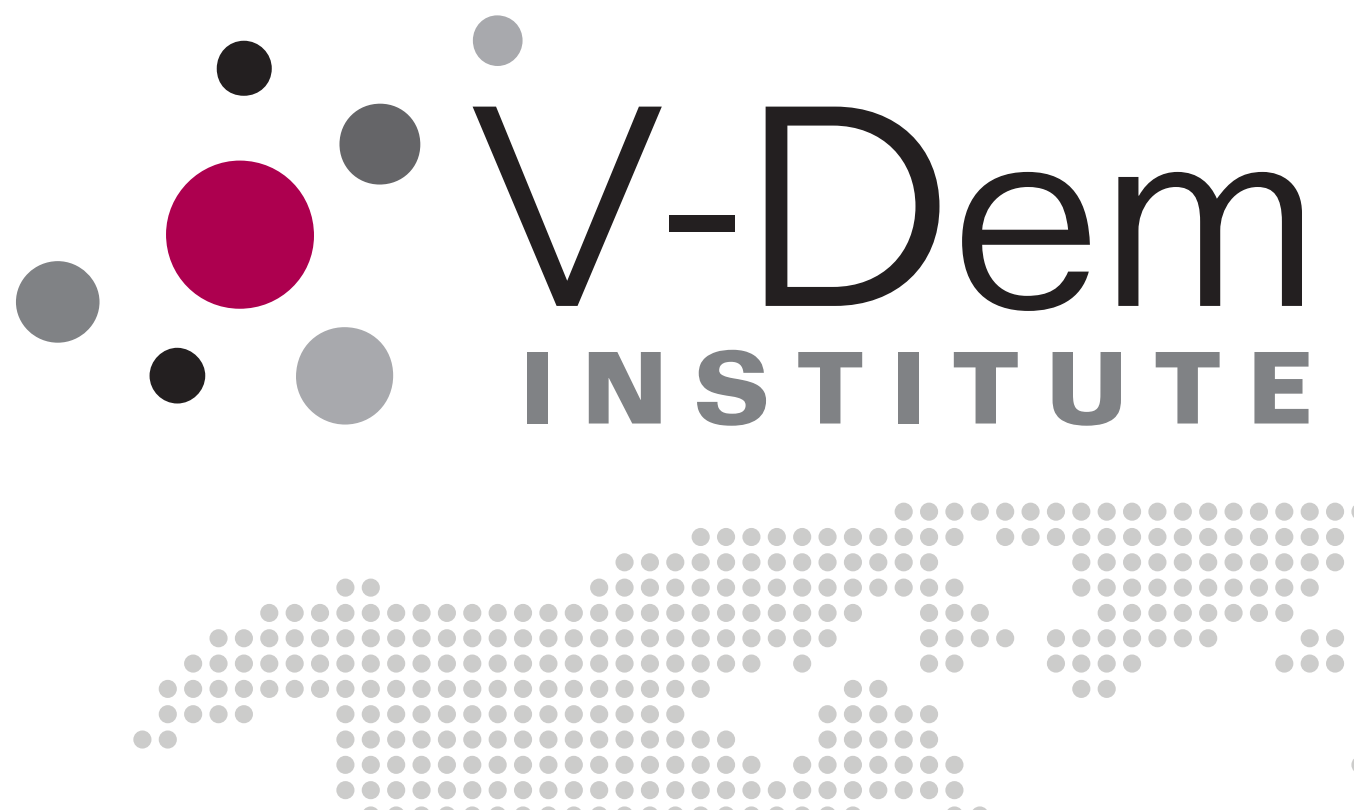

00
0
00
000
0090

$$
100
$$

900009

-

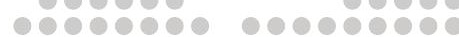
$000000000000000 \mathrm{c}$ 2000 $000000000000000 \mathrm{C}$ $0000000000000000 \mathrm{C}$

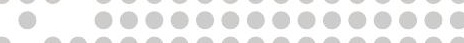

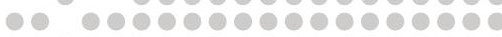

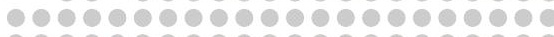
$10000000000000000 \mathrm{c}$ b000000000000000 000000000000

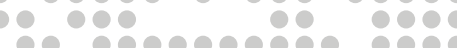
100

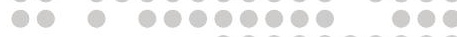
.

Varieties of Forecasts: Predicting Adverse Regime Transitions

Richard K. Morgan, Andreas Beger, Adam Glynn

resereser

0909-80

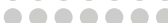

000000

00000

000

1000

10

10

O

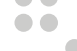

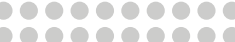

200 00000000000000 1000000000000000000 0000000000000000

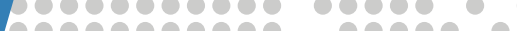

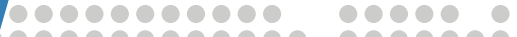

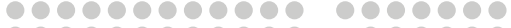

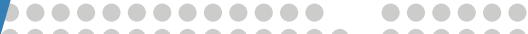
p0000000000000 000000 100000000000000

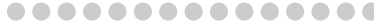

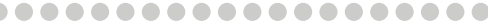

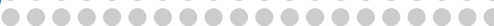
-

-

20000000000000

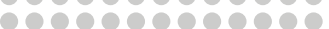

0000000000

00000000000

0000000000

o

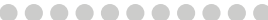

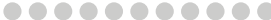

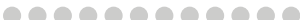
-

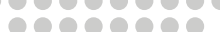

000000000

0.00000000

0000000

00000

000

000 10

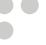

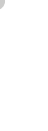

20

100

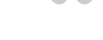


Varieties of Democracy (V-Dem) is a new approach to conceptualization and measurement of democracy. The headquarters - the V-Dem Institute - is based at the University of Gothenburg with 17 staff. The project includes a worldwide team with six Principal Investigators, 14 Project Managers, 30 Regional Managers, 170 Country Coordinators, Research Assistants, and 3,000 Country Experts. The V-Dem project is one of the largest ever social science research-oriented data collection programs.

Please address comments and/or queries for information to:

V-Dem Institute

Department of Political Science

University of Gothenburg

Sprängkullsgatan 19, PO Box 711

SE 40530 Gothenburg

Sweden

E-mail: contact@v-dem.net

V-Dem Working Papers are available in electronic format at www.v-dem.net.

Copyright (C) 2019 by the authors. All rights reserved. 


\title{
Varieties of Forecasts: Predicting Adverse Regime Transitions*
}

\author{
Richard K. Morgan \\ Varieties of Democracy Institute \\ University of Gothenburg \\ Andreas Beger \\ Predictive Heuristics \\ Adam Glynn \\ Department of Political Science \\ Emory University
}

${ }^{*}$ This research project was supported by European Research Council, Grant 724191, PI: Staffan I. Lindberg, V-Dem Institute, University of Gothenburg, Sweden; the Knut and Alice Wallenberg Foundation (PI: Staffan I. Lindberg) and the University of Gothenburg (E 2013/43), as well as internal grants from the Vice-Chancellors office, the Dean of the College of Social Sciences, and the Department of Political Science at University of Gothenburg. 


\section{Abstract}

This article introduces the V-Forecast project, the forecasting intuitive of the Varieties of Democracy (V-Dem) institute. In this the initial year of the V-Forecast project, we provide two-year ahead forecasts of the risk of adverse regime transitions (ARTs) for 169 countries. ARTs are substantial movements of a country's regime towards more authoritarian governance, whether authoritarian reversals in a democracy, or further autocratization in an already nondemocratic country. Examples include Hungary and Poland over the past few years, which are prominent cases in a more widespread and worrying global trend over that effects a significant fraction of the world's population. Yet so far, there has been no public forecasting system for anticipating new ARTs and identifying countries most at risk. We describe an effort that forecasts ARTs - operationalized using the Regimes of the World (RoW) categorization - with an ensemble model that leverages V-Dem and several additional external data sources. Despite being rare events with a roughly four percent baseline chance over any two-year period, in test forecasts the model is able to achieve good accuracy. 


\section{Introduction \& Executive Summary}

In recent years, political elites in a number of third wave democracies - most notably, Hungary, Poland, the Philippines, and Turkey - have been systematically undermining important democratic norms and institutions (Bermeo 2016, Diamond 2015, Kurlantzick 2013, Levitsky \& Ziblatt 2018, Lührmann \& Lindberg 2019, Lührmann, Mechkova, et al. 2018, Mechkova et al. 2017). In fact, no less than 24 countries experienced some form of democratic erosion between 2007 and 2017, affecting one third of the world's population and "represent[ing] a massive reduction in the global protection of rights and freedoms" (Lührmann, Dahlum, et al. 2018, p. 6). While the effects are often more diffuse and less intense than those associated with other political phenomena such as civil conflict, democratic erosion arguably has a greater negative impact on more people worldwide and over a longer term. Therefore, developing models that can help identify countries at risk of democratic erosion is of tremendous importance. This article introduces the V-Forecast project, the Varieties of Democracy (V-Dem) institute's efforts at developing these models.

There are a number of forecasting efforts currently underway throughout the international relations and comparative politics research communities. These projects range from predicting the onset of civil and international conflict (Brandt et al. 2011, Hegre et al. 2019, 2013) and mass killings and atrocities (Goldsmith \& Butcher 2018, Goldsmith et al. 2013, Woocher et al. 2018) to whether a country will experience an irregular leadership change (Beger et al. 2016, Ward \& Beger 2017) and political instability, in general (Goldstone et al. 2010). For the most part, these forecasting efforts focus on estimating the potential risk that a country will experience some form of political violence. To our knowledge, the field lacks a comprehensive forecasting system looking specifically at democratic erosion. With the goal of developing a suite of forecasting models focused on phenomena related to democratic erosion, the V-Forecast project aims to fill this gap.

As an initial step, the V-Forecast project is focusing on estimating a country's risk of experiencing an adverse regime transition (ART) within a two-year window. We conceptualize ARTs as a decline in the democratic qualities of a country's political regime. These declines can coincide with violent events such as coups and internal conflict. The military coup in Thailand in 2014 and the civil conflict (and subsequent coup) in Mali in 2012 are clear manifestations of ARTs that occur through these more violent processes. An ART can also stem from an incumbent regime's repressive response to political protests, as was the case in Bangladesh in 2012 when the government used violence to suppress protests. Further, ARTs also capture the gradual erosion of democratic norms and institutions. The events that have unfolded in Hungary over the past few years - Prime Minister Orbán's attacks on judicial constraints on executive power and his curtailment of media freedoms - is an example of this type of ART. 
We capture ARTs using the Regimes of the World (RoW) index, which classifies political regimes as either a closed autocracy, electoral autocracy, electoral democracy, or liberal democracy (Lührmann, Tannenberg, \& Lindberg 2018). While we plan to explore additional operationalization strategies in subsequent iterations of this project, we currently operationalize adverse regime transition as a year-to-year decrease in the RoW index. That is, an ART occurs when a country moves down the RoW index from one year to the next. We forecast the risk that such an event will occur within a two-year window. We describe our outcome variable in more detail in Section 2.2.

To produce our estimated risk forecasts, we use V-Dem data version 9 (Coppedge et al. 2019b, Lindberg et al. 2014) along with UN GDP and population data, ethnic power relations data (Vogt et al. 2015), coup event data (Powell \& Thyne 2011), and armed conflict data (Gleditsch et al. 2002, Pettersson \& Eck 2018), over 400 variables altogether. We use these data in three machine learning models: logit with elastic-net regularization, random forest, and gradient boosted forest. To help account for differences across these models, we use an unweighted model average ensemble. This is our preferred approach, as it helps smooth out our predictions while improving accuracy. Also, by using off-theshelf machine learning models and an unweighted average of these models, this approach is also relatively simple and quite transparent. We detail our data set and outline our estimation techniques in Section 2.

In Section 3, we discuss our framework for evaluating model performance. In particular, Section 3 describes our $2 \times 7$-fold cross-validation procedure and our performance metrics, e.g., Area Under the Curve-Precision/Recall (AUC-PR). While aggregate measures of model performance are standard practice, they do not allow researchers to assess how randomness or other fluctuations on the data might be affecting model performance from year to year. In short, the accuracy of our yearly forecasts, which is dependent on the actual observed ARTs in a given year, are likely to deviate.

To assess how robust our models are to these fluctuations, we conduct a series of yearly test forecasts for 2011 through 2017. These test forecasts mimic the process we use to generate our "live" two-year-out forecasts, allowing us to infer the general performance of our 2019-2020 forecasts. Further, to evaluate whether groups of countries with similar predicted probabilities will experience ARTs at the rate implied by the group's risk scores and to assess whether our models are over- or under-predicting ARTs, we conduct a series of calibration tests and simulation experiments.

Based on industry standards for models and prediction problems of this nature (i.e., machine learning models for rare-events), our models preform remarkably well. Our ensemble model reports an AUC-PR score of 0.46 in our $2 \times 7$ repeated cross-validation procedure and an AUC-PR score of 0.39 in our set of yearly test forecasts. As a general benchmark of performance, an AUC-PR score that is higher than the observed frequency of events in the data is a signal that the model is an improvement over chance. With an 
Figure 1: Estimated Risk of ART for 2019-2020 (Ensemble Model)
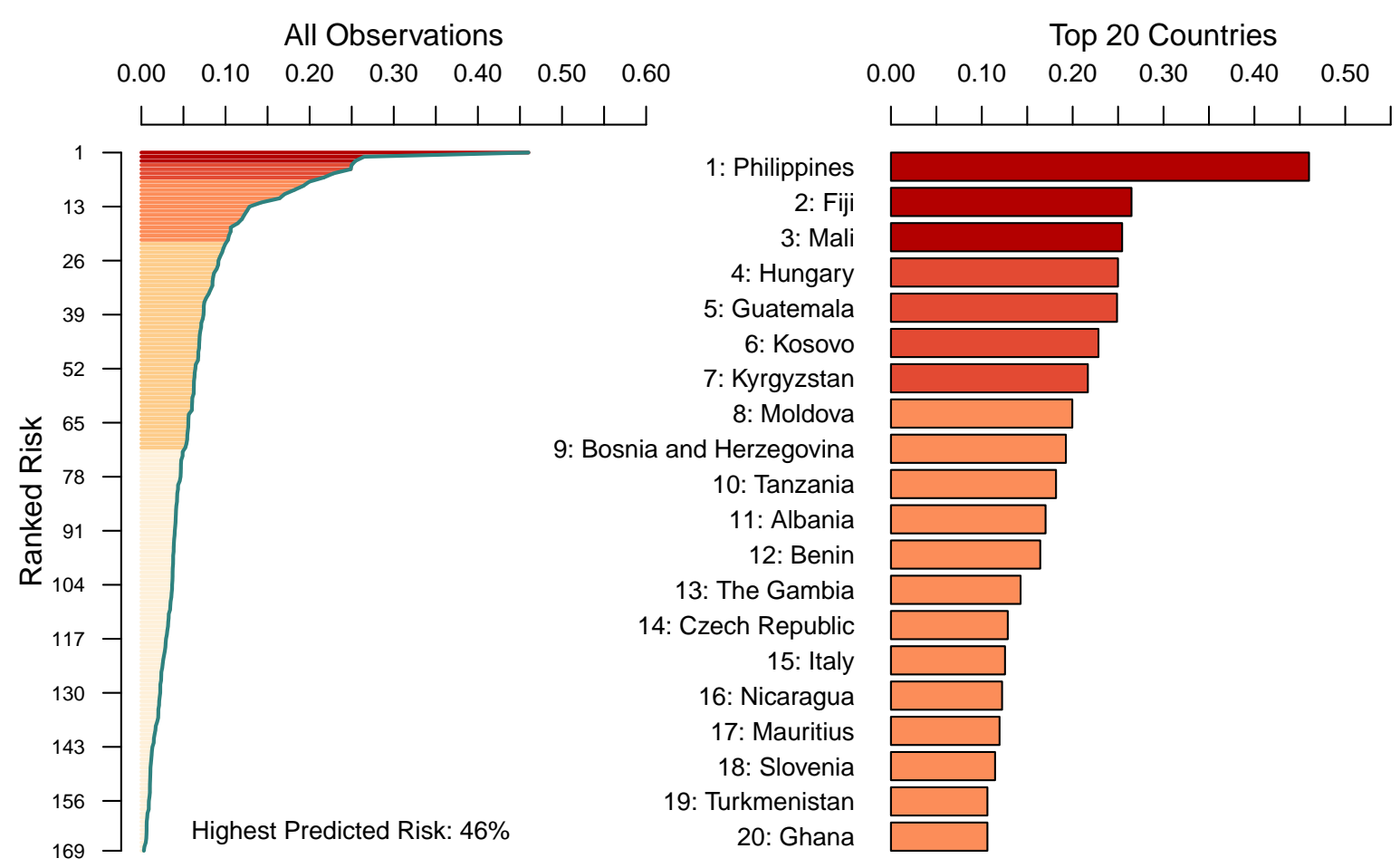

observed frequency of ARTs at roughly 4 percent, our ensemble model exceeds performance expectations.

Using the estimated probabilities for the top-ten cases for 2017-2018, we can use simulation techniques to determine how many ARTs we would have expected to occur within the set of top-ten estimates. Based on these simulations, we find that there was a 61 percent chance that at least three observations would have experienced an ART in our set from 2017-2018, with a 14 percent chance of five or more ARTs. The actual number of ARTs in the 2017-2018 top-ten estimated risk cases was five; thus, our ensemble model produced rather conservative estimates.

Looking now at our estimates for 2019-2020, the panel on the left in Figure 1 shows the range and spread of our risk estimates for 2019-2020, while the panel on the right focuses on the top-20 at-risk cases. Using these estimated probabilities, our simulation procedure suggests that there is a 75 percent chance that there will be at least two ARTs within the top-ten cases for this prediction window. Given the general performance of our ensemble model and these simulation results, a conservative estimate is that at least one of the top-ten should experience an adverse regime transition in 2019 or 2020. Section 4 provides a detailed discussion of our 2019-2020 forecasts. ${ }^{1}$

Nevertheless, it is important to note here that these forecasts are probabilistic. A high estimated risk does not mean that an ART will occur with certainty; similarly, a low estimate does not mean that an ART will not occur. Simply put, these are probabilities not certainties.

\footnotetext{
${ }^{1} \mathrm{~A}$ complete list of all 169 risk forecasts can be found in Table 7 in Appendix A
} 
Moving forward, we plan to explore other ways of operationalizing ARTs. On current approach, which relies on the RoW classification scheme, is potentially risky. The uses of threshold cutoffs across a number of different V-Dem variables when determining a country's RoW class means we run the risk of capturing small changes in border cases rather than substantial and significant decreases in the democratic qualities of a country. We address this issue in our discussion of our outcome variable, Section 2.2, and in our concluding remarks.

In the near-term, we also plan to expand the scope of this project by focusing on distinct forms of democratic erosion as well as electoral violence. In particular, we are developing a series of thematic forecasting models that estimate the risk that there will be a decline in six dimensions of democracy: (1) elections, (2) civil society, (3) freedom of expression and media, (4) public corruption, (5) democratic inclusion, and (6) legislative and judicial constraints on the use of executive power. By developing forecasting models for a variety of autocratization phenomena and by making these predictions public, the V-Forecast project hopes to provide useful tools for policy-makers and aid agencies.

\section{Methodology}

We use country-years as our unit of analysis and limit our temporal frame to 1970-2018. We reconcile the differences between the V-Dem country-year set and the Gleditsch and Ward (GW) country-year set to facilitate the use of external data (e.g., coup data, UN population data, etc.). ${ }^{2}$ This leaves 169 countries for our 2019-2020 forecasts. Our training and validation country-year set captures 7,754 observations.

\section{$2.1 \quad$ Data}

V-Dem version 9 is our primary data source; 417 of the 451 variables we have in our data set come from or are derivatives of V-Dem data. UN GDP and population data, ethnic power relations data (Vogt et al. 2015), coup event data (Powell \& Thyne 2011), and UCDP's internal armed conflict data (Gleditsch et al. 2002, Pettersson \& Eck 2018) make up the remaining 34 variables in our data set. We lag all variables one year and derive the first differences for a number of variables. In brief, we use data from 2011 to estimate the risk that an ART will occur in 2012 or 2013, for example. A complete list of variables as well as basic descriptive statistics can be found in Appendix E.

\footnotetext{
${ }^{2}$ We drop the following eight countries from the V-Dem set: São Tomé and Principe, Seychelles, Vanuatu, Palestine/West Bank, Palestine/Gaza, Somaliland, Hong Kong, and Zanzibar, as they lack coverage in the GW country-year set. Along with micro-states, we drop the following four countries from the GW set: Bahamas, Belize, Malta, and Brunei, as they lack coverage across the V-Dem county-year set. We also drop Bahrain from the GW set. While the V-Dem data provides some coverage of Bahrain, there are missing values for the entire series of Bahrain across a number of key indices; therefore, we excluded it. The number of countries in our data per year ranges from 137 to 169 .
} 
There are several missing values throughout the V-Dem data. For the most part, this missingness is concentrated around variables related to elections and the legislative branch. Most missingness is the product of four V-Dem coding rules: (1) when elections are permitted, election specific variables are not scored for the years between elections, (2) when elections are not permitted or when there is an interruption, all elections variables during that period are not recorded, (3) in the event of an interruption, key legislativerelated variables are also not recorded, ${ }^{3}$ and (4) legislative-related variables are not coded for the first year that institution was enacted.

When elections are permitted, we fill in missing variables by carrying forward the last non-missing value. If an election-related variable is missing because elections were not permitted or because there was an interruption, we set these observations to zero and create a dummy variable indicating whether the elections were, in theory, permitted. Similarly, when legislative-related variables are missing due to an interruption, we set these observations to zero and create a dummy variable signaling this change. ${ }^{4}$ Finally, we back-fill all legislative variables that are missing because it is the first year of that there was a viable legislative branch. We maintain annotated code for all changes made to the original V-Dem v9 data. ${ }^{5}$

\subsection{Adverse Regime Transitions}

We operationalize adverse regime transitions using the Regimes of the World (RoW) index. This index classifies political regimes as either a closed autocracy, electoral autocracy, electoral democracy, or liberal democracy. To produce these classifications, the RoW index takes into account the quality of a country's electoral institutions (e.g., the presence of multiparty elections and the quality of these elections), its liberal characteristics (e.g., legislative and judicial constraints on the use of executive power), as well as the regime's record across various civil liberties indices (e.g., adherence to the rule of law and secure and effective access to the judicial system). ${ }^{6}$ An adverse regime transition occurs when a country moves down this scale (going from an electoral autocracy to a

\footnotetext{
${ }^{3}$ According to the V-Dem Codebook, an "interruption" is typically the result of a coup, declared state of emergency, or military defeat (For election variables, see Coppedge et al. (2019a, p. 275), and for legislative variables, see Coppedge et al. (2019a, p. 46 and 132-35).

${ }^{4}$ In the Data Appendix E below these variables are named is_elec and is_leg.

${ }^{5}$ Our data management $\mathrm{R}$ code is available upon request.

${ }^{6}$ Specifically, the RoW index classifies countries according to the following criteria: "Electoral democracies score above 2 on the indicators for multi-party (v2elmulpar_osp) and free and fair elections (v2elfrfair_osp), as well as above 0.5 on the Electoral Democracy Index (v2x_polyarchy). Liberal democracy meets the criteria for Electoral democracy but also satisfy the liberal dimensions by a score above 0.8 on the V-Dem Liberal Component index (v2x_liberal), as well as a score above 3 on transparent law enforcement (v2cltrnslw_osp), access to justice for men (v2clacjstm_osp) and women (v2clacjstw_osp). Electoral autocracies fail to meet one or more of the above-mentioned criteria of electoral democracies, but subject the chief executive and the legislature to de-jure multiparty elections as indicated by a score above 1 on the V-Dem multiparty elections indicator (v2elmulpar_osp_leg/_ex). Closed autocracies do not satisfy the latter criterion" (Coppedge et al. 2019a, p. 219).
} 
Table 1: Year-to-Year Transition Frequency Table - 1970-2018

To:

\begin{tabular}{ll|rrrr} 
& $\begin{array}{c}\text { Liberal } \\
\text { Democracy }\end{array}$ & $\begin{array}{c}\text { Electoral } \\
\text { Democracy }\end{array}$ & $\begin{array}{c}\text { Electoral } \\
\text { Autocracy }\end{array}$ & $\begin{array}{c}\text { Closed } \\
\text { Autocracy }\end{array}$ \\
\cline { 2 - 5 } From: & Liberal Democracy & $20.45 \%$ & $\mathbf{0 . 3 0 \%}$ & $\mathbf{0 . 0 0 \%}$ & $\mathbf{0 . 0 0 \%}$ \\
Electoral Democracy & $0.52 \%$ & $19.18 \%$ & $\mathbf{1 . 0 1 \%}$ & $\mathbf{0 . 1 2 \%}$ \\
Electoral Autocracy & $0.03 \%$ & $1.70 \%$ & $25.05 \%$ & $\mathbf{1 . 0 2 \%}$ \\
Closed Autocracy & $0.00 \%$ & $0.09 \%$ & $1.92 \%$ & $28.63 \%$
\end{tabular}

closed autocracy, for example) from one year to the next. We provide a complete list of all ARTs in Appendix D.

One concern with our current operationalization is that we may be identifying small real-world changes when the underlying components of the RoW variable start near the RoW thresholds. In future work, we will assess robustness with alternative operationalizations of ARTs. Nonetheless, we should note that most recorded ARTs represented substantial adverse events or are part of a sustained, but gradual democratic erosion processes. Take, for example, the ART we capture in Togo in 2016 when the regime was downgraded from an electoral democracy to an electoral autocracy. While Togo was a border case on key RoW component variables in 2015, the events that pushed Togo past the threshold were significantly detrimental. For example, in the run-up to the 2015 elections, the government banned all forms of protest and imprisoned political opposition leaders and supporter. Further, Amnesty International reports that a number of those detained were tortured while others were put on trial without access to a lawyer.

Conversely, the ART that we capture in Albania in 2017, for example, seems to be a function of a slight decrease in the Liberal Component index. It was a liberal democracy in 2016 but was downgraded to an electoral democracy in 2017 when its score on the Liberal Component index fell from 0.8 to 0.79 , thus below the threshold of 0.8 used by the RoW index to classify a country as a liberal democracy. However, Albania (and similar cases) represent regimes that are influx; they are fragile regimes, unstable in their current class. Our models should be able to identify which of these unstable regimes are in greater need of democracy support.

Table 1 presents the frequency of all movements in the RoW index at yearly level; bold text highlights the frequency of ARTs. There were 189 adverse regime transitions, or roughly 2.4 percent of our country-year observations. There was no change in the RoW index in 93.31 percent of our observations. From 1970 to 2018, the average number of adverse regime transitions per year was 3.86, with a standard deviation of 2.34 , and the maximum number of adverse regime transitions in a year was ten in 2010 while two years (1986 and 2011) experienced no adverse regime transitions. 
Figure 2: Adverse Regime Transitions by Year

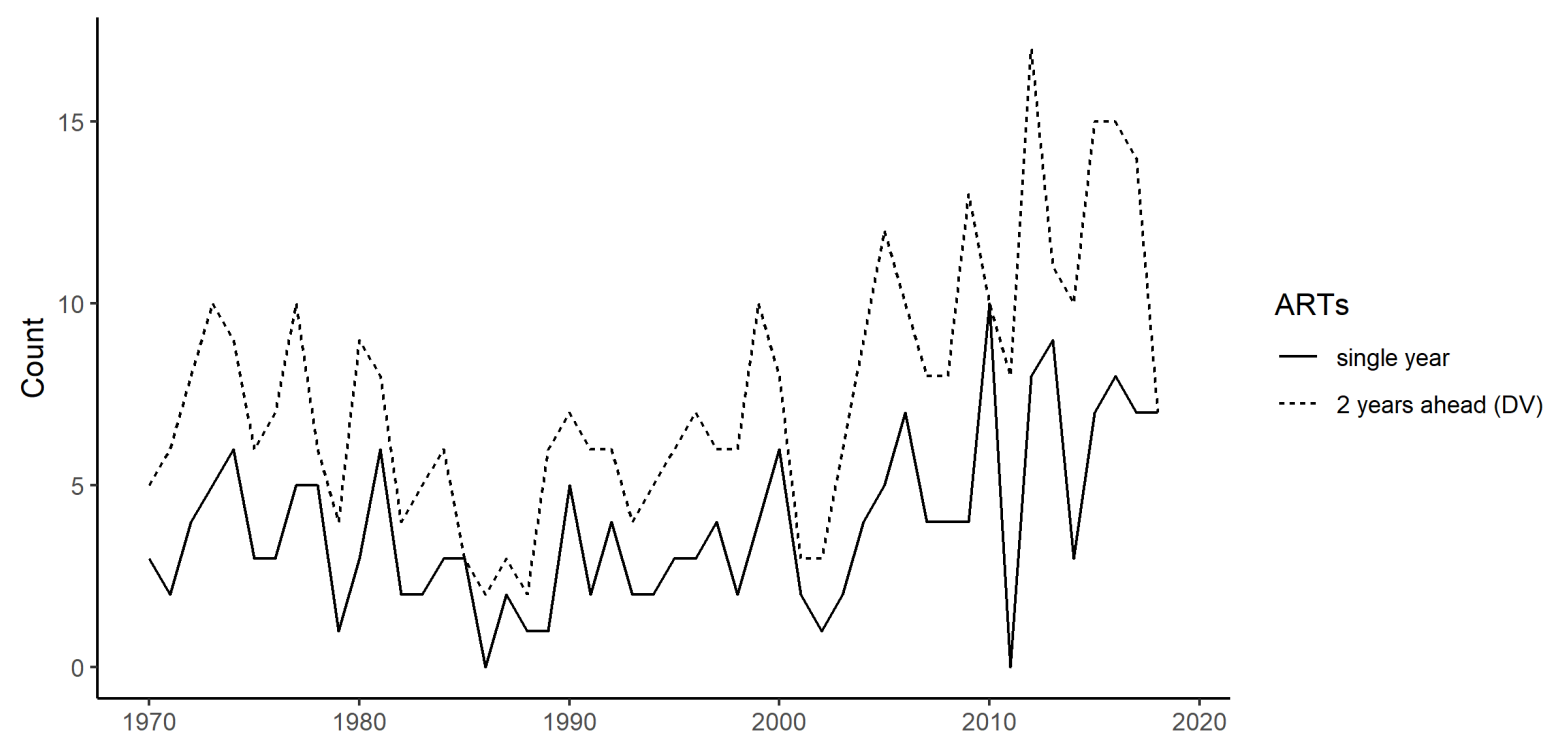

Because we are interested in forecasting the estimated risk that an ART will occur within a two-year window, our dependent variable records a country-year observation a one if there is any negative change in the RoW index within the next two years, zero otherwise - e.g., if country $X$ experienced an ART in 2013, this event is reflected in the data (coded as a one) for 2012 and 2013. This increases the number of positive cases to 369 (4.76 percent). This is slightly less than double the number of year-to-year ARTs, as Bolivia, Malaysia, and Somalia experienced an adverse regime transition in the first year of our sample (1970), while other countries experienced adverse regime transitions in two consecutive years (Chile in 1973 and 1974, Argentina in 1976 and 1977, Bangladesh in 2006 and 2007, and Thailand in 2013 and 2014), or had two adverse regime transitions within three years (Cambodia in 1971 and 1973 and Guinea-Bissau in 2008 and 2010).

Figure 2 plots the number of ARTs per year (1970-2018) as well as the number of ARTs that occurred within the two-year window (our dependent variable). The yearly average number of ARTs that occur within a two-year window was 7.53, with a standard deviation of 3.46. The maximum number of adverse regime transitions within a two-year window was 17 in 2012. Two years, 1986 and 1988, experienced the minimum number of ARTs (two) within a two-year window. As the yearly number of countries in our sample ranges from 135 to 169, the effective positive rate of our dependent variable in any given year varies from around 1.4 percent to 10 percent; roughly 75 percent of our yearly positive rates are between 3.8 percent and 5.6 percent. 


\subsection{Modeling}

Looking across the universe of adverse regime transitions, one thing is clear: incumbent political elites can lead their country down a number of different paths that would trigger an adverse regime transition (Coppedge 2017). This equifinality - the different political processes that can lead to an ART - complicates the use of more traditional methodological approaches in prediction problems. Indeed, while traditional methods of description, explanation, and inference can perform well at explaining the onset of important political events ex-post, when researchers apply these well-established methods to prediction problems, they tend to perform poorly (Beger et al. 2016, Hill \& Jones 2014, Schrodt 2014, Soyer \& Hogarth 2012, Ward et al. 2010). To overcome these problems, social scientists have been borrowing forecasting methods from other fields - machine learning methods from computer science, in particular. While machine learning methods are not a panacea (Bowlsby et al. 2019, Cederman \& Weidmann 2017), they do offer promise, in the form of improved out-of-sample accuracy, over more traditional methods.

This project uses an unweighted model average ensemble built around three machine learning models: logit with elastic-net regularization, random forest, and gradient boosted forest. ${ }^{7}$ Each of these forecasting algorithms takes advantage of the full set of covariates within our expansive dataset, which helps them account for the different, complex, and interrelated political processes that can lead to an adverse regime transition. However, because each of algorithm samples and processes the data differently when calculating the predicted risk of an ART event, some models are better able to predict specific cases. Further, the within method variance of the assigned predicted probabilities tends to be quite different.

For example, relative to our gradient boosted forest model, our random forest model generally produces more gradual, incremental increases in its predicted risk estimates. For our prediction problem, the gradient boosted forest model tends to produce a lot of really low estimates followed by a handful of relatively high estimates. Moreover, the estimates from our logit with elastic-net regularization model tend to be too conservative while our random forest model tends to produce very large estimates. Thus, the unweighted model average ensemble is our preferred approach to estimation, as it not only helps smooth out our predicted risk estimates, but it also improves accuracy, as measured by standard performance statistics.

The machine learning models we use in our ensemble model are becoming increasingly popular among social scientists. For example, the Early Warning Project uses the logit with elastic-net regularization method to forecast mass killings (Woocher et al. 2018), and the random forest model is one of the methods Hegre et al. (2019) at the ViEWS project use to predict various types of political violence. However, while Gohdes (2019) uses the

\footnotetext{
${ }^{7}$ We provide a brief, nontechnical overview of the mechanics behind each of these machine learning methods in Appendix B.
} 
gradient boosted forest method for a classification problem looking at the relationship between internet accessibility and the type and target of political violence in Syria, to our knowledge, we are the first to adapt this approach to a forecasting problem centered around a distinct political phenomenon.

\section{Evaluating model performance}

Our framework for evaluating overall model performance is two-fold, and entirely based on out-of-sample performance:

1. Repeated $k$-fold cross-validation on the training period from 1970 to 2017 in order to obtain out-of-sample predictions for those years.

2. A series of test forecasts for the years from 2011 to 2017 that mimic the process we use to generate our "live" two-year-out forecasts for 2019-2020.

The first approach, the repeated $k$-fold cross-validation, allows us to assess out-ofsample performance for the complete history the models use for training. The objective of this procedure is to assess a model's ability to predict new, out-of-sample data (i.e., the generalizability of a model, or rather how well a model should preform given new data). In short, $k$-fold $k$-fold cross-validation (CV) procedures work by randomly dividing all observations into $k$ roughly equally-sized groups. In series, each unique group is set aside to serve as "test data," while the remaining $k-1$ groups are "training data." These training data are used to fit a model, while the test data is used to evaluate the performance of this fitted model. This process is repeated $k$ times. Thus, each of the $k$-groups of observations are used once in the testing phase and $k-1$ times in the training phase. The average performance statistics from these train/test iterations provide researchers with a general sense a model's predictive accuracy.

One concern with the standard $k$-fold CV approach is that the processes that led to ARTs in the past might be different from the processes that trigger ARTs in more recent years. Thus, it is important to check how well a model performs under conditions that mimic current conditions. The second approach, our set of yearly test forecasts, addresses this concern. These test forecasts give us a better assessment of recent performance and how well the live forecasts are likely to perform. It also gives us some insight in how much performance differs from year to year due to randomness or other fluctuations.

In addition to assessing overall performance, we also examined two additional aspects. The first is calibration, which examines how accurate or valid the probabilities produced by the model are. The second is a simulation experiment where we assess how well the global number of ARTs implied by the model's forecasts matches observed numbers of ARTs. 
Table 2: Repeated cross-validation $(2 \times 7)$ performance, 1970-2017

\begin{tabular}{lrrr}
\hline Model & AUC-ROC & AUC-PR & Brier \\
\hline Logit w/Elastic-net Regularization & 0.85 & 0.30 & 0.039 \\
Random Forest & 0.91 & 0.40 & 0.035 \\
Gradient Boosted Forest & 0.92 & 0.42 & 0.035 \\
Ensemble & $\mathbf{0 . 9 3}$ & $\mathbf{0 . 4 6}$ & $\mathbf{0 . 0 3 4}$ \\
\hline
\end{tabular}

We summarize the performance of our models using three standard statistics: Brier, Area Under the Curve-Receiver/Operating Characteristic (AUC-ROC), and Area Under the Curve-Precision/Recall (AUC-PR) scores. The Brier score is the mean squared difference between the predicted probability and the observed outcome. The AUC-ROC metric measures the balance between the true positive rate and the false positive rate at different acceptance thresholds (the value in which a predicted probability is classified as a one). The AUC-PR metric measures the trade-off between precision, the positive predictive value, and recall, the true positive rate, across the range of acceptance thresholds. ${ }^{8}$

For the Brier score, the lower the score, the better; however, higher AUC-ROC and AUC-PR scores suggest better model performance. Moreover, an AUC-ROC score above 0.50 signals that the model is preforming better than random chance. And, an AUC$\mathrm{PR}$ score that is higher than the observed frequency of events in the data is a signal that the model is an improvement over random chance. For class-imbalanced prediction problems (when the dependent variable is a rare event) like the one currently under consideration, the AUC-PR measure is better suited since it is more sensitive to how well a model predicts positive cases. Thus, the AUC-PR is our preferred metric of assessment performance.

\subsection{Cross-validation}

Due to the sparsity of our dependent variable, we use a 7-fold CV procedure to help ensure variation in our dependent variable within each test/train split. We repeat this process two times $(2 \times 7$-fold $\mathrm{CV})$, recording the mean predicted value for each observation and comparing these scores to the observed value. Since this cross-validation assessment covers a larger number of cases, it provides a more robust accuracy estimate.

Table 2 summarizes the results from our $2 \times 7 \mathrm{CV}$ procedure for our ensemble and component models. From Table 2, we see that our ensemble model outperforms our other models across our three performance metrics. Figure 3 presents a series of separation plots based on our $2 \times 7 \mathrm{CV}$ procedure. To produce these plots, we sort the average

\footnotetext{
${ }^{8}$ True Positive Rate $=$ True Positives $/($ True Positives + False Negatives); False Positive Rate $=$ False Positives / (False Positives + True Negatives); Positive Predictive Value $=$ True Positives / (True Positives + False Positives).
} 
Figure 3: Separation plots from the $2 \times 7$-fold CV procedure, 1970-2017

\section{Logit w/Elastic-net Regularization}
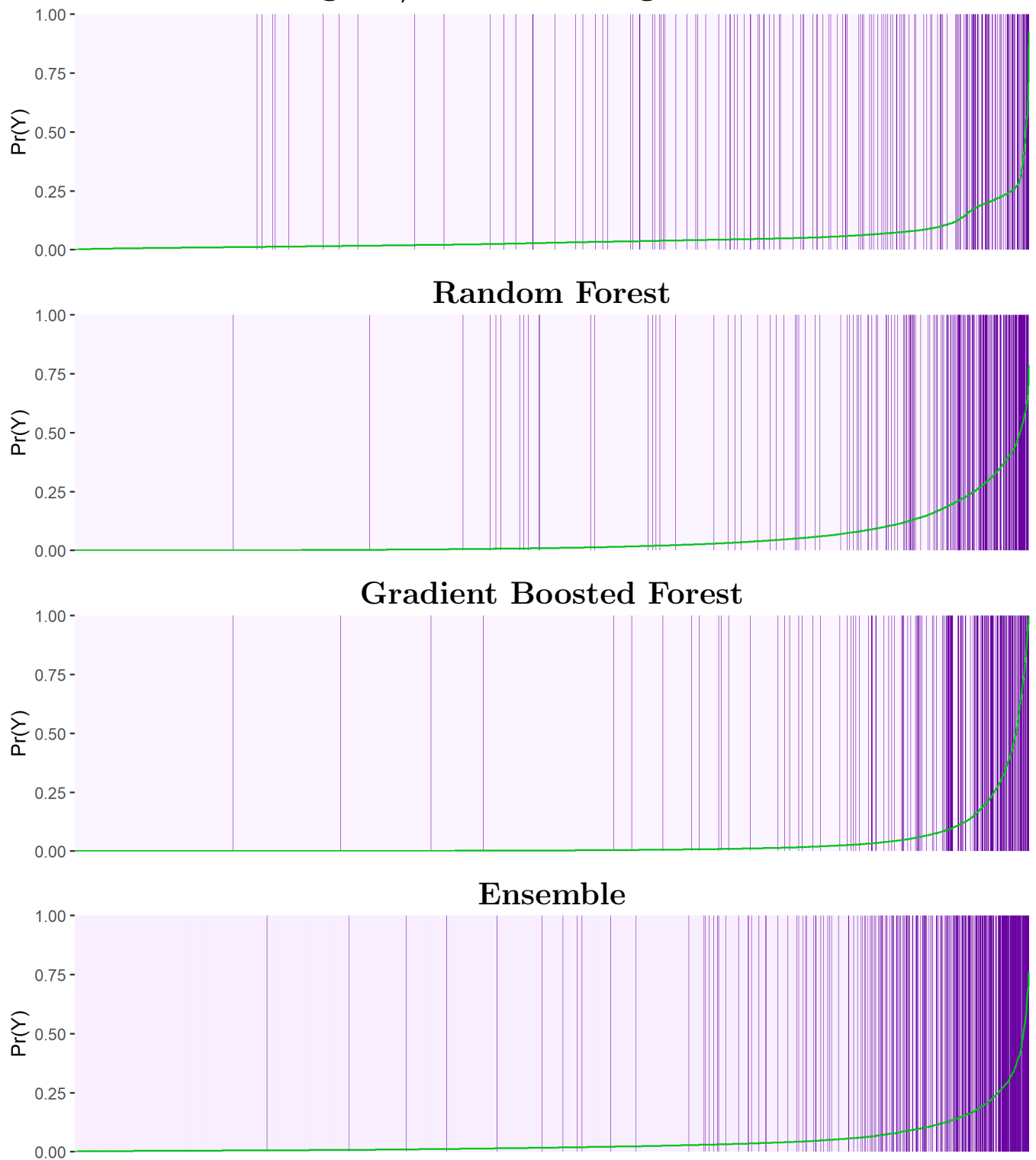

predicted probability for each observation from our $2 \times 7 \mathrm{CV}$ procedure (the green line running horizontally) and highlight whether an observation had an ART within the twoyear prediction window (the dark purple vertical lines). The more concentrated the dark purple lines are to the right of the plot, the better the model performs within our $2 \times 7$-fold CV framework.

The green average predicted probability line for each of the three machine learning models highlights the variability of estimates produced by these different methods. The step-like jump at the right side of the elastic-net plot, the relatively higher predictions across the random forest plot, and the sharp, almost exponential increase seen in the gradient boosted forest plot add justification for using an unweighted average model ensemble. As seen in the bottom plot, the ensemble model helps address these differences. 
Table 3: Test forecast performance, 2011-2017 (pooled)

\begin{tabular}{lrrr}
\hline Model & AUC-ROC & AUC-PR & Brier \\
\hline Logit w/Elastic-net Regularization & 0.78 & 0.26 & 0.064 \\
Random Forest & 0.82 & 0.37 & 0.059 \\
Gradient Boosted Forest & 0.81 & 0.36 & 0.061 \\
Ensemble & $\mathbf{0 . 8 4}$ & $\mathbf{0 . 3 9}$ & $\mathbf{0 . 0 5 9}$ \\
\hline
\end{tabular}

\subsection{Yearly test forecasts}

Our series of yearly test forecasts provide a better assessment of the expected accuracy of our "live" forecasts since they more closely replicate those conditions and reflect year-toyear variance in forecast accuracy, which depends heavily on variation in realized adverse regime transitions in a given year. This requires that we conduct a series of train/test experiments. We first train our models using all data from 1970 to 2010. We then use data from 2011 to produce estimated risk forecasts for 2012-13 and evaluate how well our models preformed. We then retrain our models using all data from 1970 to 2011, use data from 2012 to produce estimates for 2013-14, and evaluate model performance. We conduct this iterative model check procedure for all years, 2011 to 2017.

Table 3 summarizes the results for all of the yearly test forecasts. Here too we see that our ensemble model outperforms our other models. Thus, while we present all relevant information for each of the component models in Appendix C, our discussion moving forward will now center on the general performance of our ensemble model.

While pooled summary assessment like those found in Tables 3 and 2 are the standard way to gauge a model's accuracy, the accuracy of the forecasts in any given year is going to deviate to some extent from the overall mean measures. Table 4 show the performance of our ensemble model for each of our yearly test forecasts. For the AUC-ROC column, a score greater than 0.5 is an indicator that the model performed better than the baseline for that year. And, for the AUC-PR a score greater than the observed positive rate in the data, listed under the $\bar{Y}$ column, is an indicator that the model outperformed the baseline for that year.

The AUC-ROC values range from a minimum and maximum of 0.74 to 0.95 , with most values in the 0.8 range. The AUC-PR values are more variable, which is expected for rare outcomes like these ARTs. It ranges from 0.15, which is low but still an informative improvement over that year's 0.05 base rate, to 0.51 . Overall, there is a lot of variation in performance from year to year; however, the performance metrics for each year suggest that our ensemble model is an improvement over naive models. 
Table 4: Performance of the tests forecasts by year, Ensemble model

\begin{tabular}{rrrrr}
\hline Year & AUC-ROC & AUC-PR & $\bar{Y}$ & ARTs \\
\hline 2011 & 0.74 & 0.15 & 0.05 & 8 \\
2012 & 0.88 & 0.51 & 0.10 & 17 \\
2013 & 0.95 & 0.41 & 0.07 & 11 \\
2014 & 0.84 & 0.23 & 0.06 & 10 \\
2015 & 0.81 & 0.30 & 0.09 & 15 \\
2016 & 0.88 & 0.49 & 0.09 & 15 \\
2017 & 0.81 & 0.37 & 0.08 & 14 \\
\hline
\end{tabular}

\subsection{Model calibration}

The model's forecasts are probabilities ranging from zero to one, where values near zero and one indicate near certainty that an event will not or will occur, respectively. In a well-calibrated model, we can take the probabilities at face value, e.g., if we had a set of countries with forecasts of 0.5 , we can expect that roughly half of them experience an ART, and we should observe that this was indeed the case in the real world.

One way to assess this question is to bin the model's probabilities into equally sized groups of similar probabilities, e.g., top ten percent, next ten percent, etc., and compare the number of ARTs implied by the set of probabilities in a bin to the actual number of ARTs that occurred for those countries. Table 5 shows the results if we do this with the full set of cross-validation out-of-sample predictions (i.e., from our $2 \times 7 \mathrm{CV}$ procedure). The first column shows the probability ranges that we use for grouping, or binning, cases. They were chosen to divide the data into 10 equal groups of increasing probabilities. Note that the model's predictions are strongly skewed, with the majority of probabilities falling near zero, and less than a tenth falling above a probability of 0.1 . The second and third columns show the average probability for a bin and the implied number of ARTs we would have expected to see. The last two columns show the actual number of ARTs observed and whether, as a result, the model's predictions in that bin were too high ("+") or too low ("-"). The model's forecasted probabilities are slightly too high for lower risk countries, about 80 percent of cases, and too low for the higher risk countries in the remaining 20 percent. Overall, the total number of ARTs predicted out of sample is fairly conservative, with 343 anticipated ARTs against 369 observed ARTs.

Figure 4 is a calibration plot that also shows the model predictions, on the x-axis, against observed outcomes on the y-axis. The black points correspond to the "Mean P" and rate of "Actual ARTs" (i.e., observed ARTs over number of cases in a bin) from Table 5. The blue line is a smoothed estimate of the relationship between the two, which confirms the interpretation above. Below probabilities of 0.05 , the model is too aggressive, while above 0.05 it is too conservative and underpredicts. 
Table 5: Calibration: expected versus actual number of ARTs by forecast decile, Ensemble model

\begin{tabular}{lrrrc}
\hline Bin & Mean P & Expected ARTs & Actual ARTs & Direction \\
\hline$[0.0009,0.004]$ & 0.003 & 2.3 & 0 & + \\
$(0.004,0.006]$ & 0.005 & 3.9 & 0 & + \\
$(0.006,0.008]$ & 0.007 & 5.5 & 2 & + \\
$(0.008,0.012]$ & 0.010 & 7.9 & 2 & + \\
$(0.012,0.017]$ & 0.015 & 11.5 & 2 & + \\
$(0.017,0.024]$ & 0.021 & 16.0 & 5 & + \\
$(0.024,0.034]$ & 0.029 & 22.3 & 9 & + \\
$(0.034,0.053]$ & 0.042 & 32.5 & 21 & + \\
$(0.053,0.111]$ & 0.076 & 59.0 & 71 & - \\
$(0.111,0.759]$ & 0.235 & 182.6 & 257 & - \\
\hline
\end{tabular}

Figure 4: Calibration plot, Ensemble model

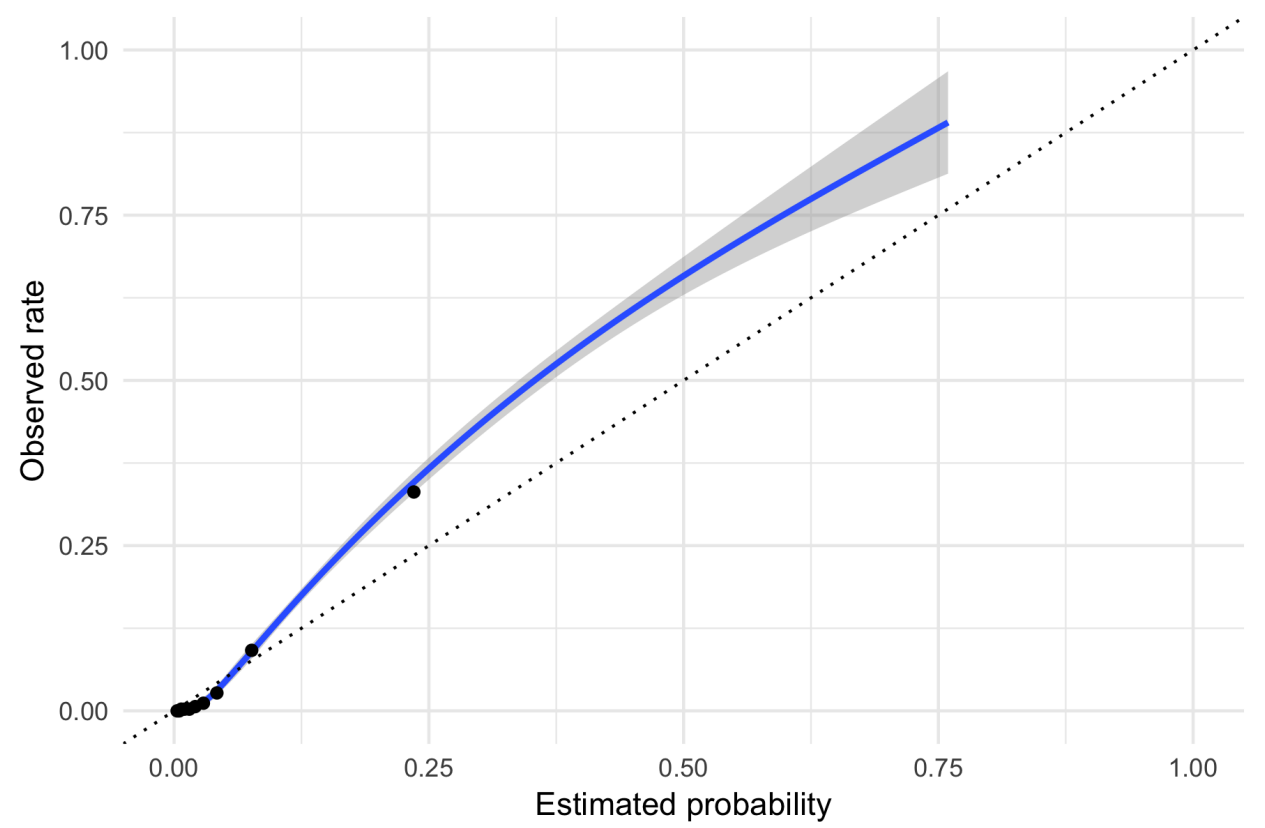

\subsection{Simulations}

Another way to assess the forecasts from our ensemble model is to evaluate how well our yearly test forecast collectively match the real-world outcome we observed in a given year. To do this we can take all of the model's forecasts for a year, which gives us a set of 169 probabilities, and then we "simulate" the world by drawing hypothetical ARTs for each country in accordance with the respective probabilities. It is as if we had a coin to represent each country, flipped them all, and counted the number of heads we get. Except that the coins are all biased in accordance with the model forecasts. With a perfect model, we would expect that the number of hypothetical ARTs we get in this 
Figure 5: Expected number of worldwide ARTs given the ensemble model's test forecasts.

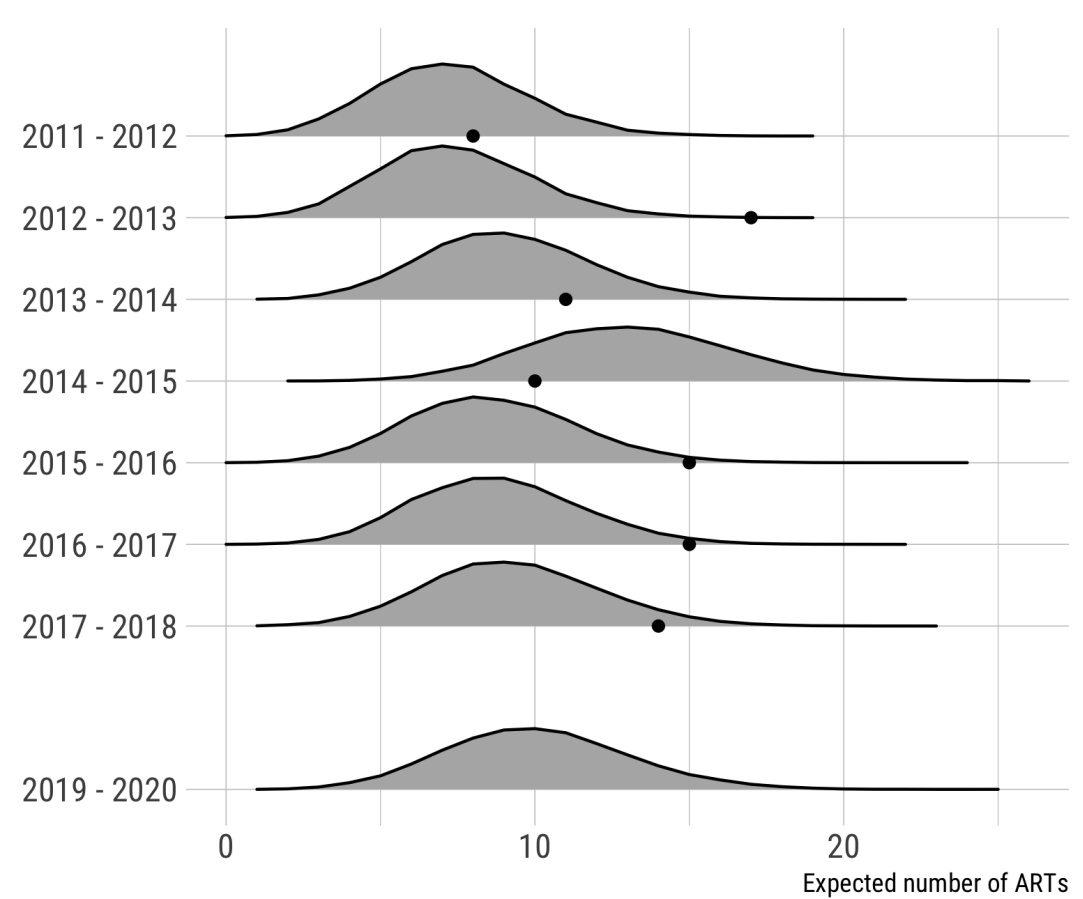

simulation to more or less match the number of ARTs we observe in reality. There is a lot of randomness here: one simulation will likely be different from another. So, we do 20,000 of them, and count up how many ARTs each simulated world gave us. We repeat this process for all test year forecasts.

Figure 5 shows the output of our simulation experiment. The gray densities summarize the number of ARTs we got in each of the 20,000 simulated worlds. Each black dot is the actual number of ARTs that happened that within a specific two-year forecast window. So, for example, for the 2011-2012 window, our simulations were pretty close to the observed outcome, whereas for the next 2012-2013 window, the actual number of ARTs was much higher than our simulations would have led us to believe. Overall, the output from these simulations again suggest that our ensemble model is somewhat conservative and under-predicts the global number of ARTs by about two to four in any given forecast window.

\section{Current forecasts}

Based on the simulations using the forecasts 2019-2020, we expect there to be between five and 15 ARTs overall; 90 percent of our simulations fall into this range. The most likely number of ARTs in our 2019-2020 forecast window is ten; at 13 percent, this is the modal category in our simulation. By doing the simulation exercise with only the top 
Table 6: Top 20 Estimated Risks, 2019-2020

\begin{tabular}{rlllr}
\hline & Country & $\begin{array}{l}\text { Estimated } \\
\text { Risk }\end{array}$ & $\begin{array}{l}\text { RoW } \\
\text { Classification }\end{array}$ & $\begin{array}{r}\text { Year since } \\
\text { last ART }\end{array}$ \\
\hline 1 & Philippines & 0.460 & Electoral Democracy & 14 \\
2 & Fiji & 0.265 & Electoral Democracy & 2 \\
3 & Mali & 0.254 & Electoral Democracy & 6 \\
4 & Hungary & 0.250 & Electoral Democracy & 8 \\
5 & Guatemala & 0.249 & Electoral Democracy & 35 \\
6 & Kosovo & 0.228 & Electoral Democracy & 6 \\
7 & Kyrgyzstan & 0.217 & Electoral Democracy & 2 \\
8 & Moldova & 0.200 & Electoral Democracy & 10 \\
9 & Bosnia and Herzegovina & 0.193 & Electoral Democracy & 26 \\
10 & Tanzania & 0.182 & Electoral Democracy & 2 \\
11 & Albania & 0.170 & Liberal Democracy & 1 \\
12 & Benin & 0.164 & Liberal Democracy & 3 \\
13 & The Gambia & 0.143 & Electoral Democracy & 23 \\
14 & Czech Republic & 0.129 & Liberal Democracy & 79 \\
15 & Italy & 0.126 & Liberal Democracy & 94 \\
16 & Nicaragua & 0.122 & Electoral Autocracy & 11 \\
17 & Mauritius & 0.120 & Liberal Democracy & 1 \\
18 & Slovenia & 0.115 & Liberal Democracy & 29 \\
19 & Turkmenistan & 0.106 & Electoral Autocracy & 6 \\
20 & Ghana & 0.106 & Liberal Democracy & 3 \\
\hline
\end{tabular}

20 forecasts, we can also derive some expectations for how many of those countries will experience an ART. This procedure suggests that the most likely number of ARTs in the top 20 is four; 90 percent of our simulations fell between one and seven ARTs.

Table 6 presents these top 20 at-risk countries for 2019-2020. Aside from a country's rank and its estimated risk, Table 6 also includes the country's RoW classification for 2018 and the number of year since it last experienced an ART. ${ }^{9}$ For careful observers, a number of these top 20 countries should not come as a surprise. In fact, recent news reports suggest that some of these countries are already displaying signs of adverse regime transition. We discuss a few of these cases below.

The actions of President Duterte of the Philippines over the last few years are reason for concern. Since his election in 2016, President Duterte has demonized journalists, labeling them spies and downplayed the assassination of reporters (Schmidt 2017). ${ }^{10}$ Unsurprisingly, Philippines' score on V-Dem's Freedom of expression and alternative sources of information index has declined substantially from 0.90 in 2015 to 0.77 in 2018.

\footnotetext{
${ }^{9} \mathrm{~A}$ complete list of all 169 risk forecasts can be found in Table 7 in Appendix A

${ }^{10}$ Schmidt also quotes then-president elect Duterte saying "Just because youre a journalist you are not exempted from assassination if youre a son of a bitch," in 2016 just before his inauguration.
} 
Further, one outcome of President Duterte's so-called war on drugs is a marked increase in extra-judicial killings. This is reflected in a substantial and statistically significant 0.3-point decrease in V-Dem's Physical Violence Index: It went from 0.58 in 2015 to 0.28 in 2018. President Duterte's undermining of democracy include legislative constraints on executive power. President Duterte's governing Coalition for Change enjoys a majority in the Senate (12 out of 24 seats) and a super majority in House of Representatives (258 out of 297 seats) and V-Dem's Legislative constraints on the executive index also decreased substantially and statistically significantly from 0.76 in 2015 to 0.44 in 2018.

The developments in the Philippines in just these last three years are arguably foreboding. Our ensemble model accurately picks up on these as well as a range of other tends in the data, producing a high estimated risk that the Philippines will become an electoral autocracy in the next two years. Indeed, as of this writing, the Philippines have not yet held their mid-term elections, which are scheduled for 13 May 2019. However, some observes fear that these elections will help Duterte further consolidate his power (Kishi \& Raleigh 2019)

In Mali, a recent uptick in violence and the government's failure to curb militia violence, led to the resignation of the entire Malian government in April (al Jazeera News Agency 2019, Quashie-Idun \& Swails 2019). In Guatemala, President Morales is taking steps to oust supreme court justices who overturned his decision to expel the United Nations-backed International Commission Against Impunity in Guatemala, which has a mandate to root-out corruption high-profile crimes in the country (Amnesty International 2019a, Eulich 2019). Endemic corruption, the erosion of judicial independence, and human rights abuses have pushed people to the streets in protest and the country to a breaking point.

The gradual, yet persistent erosion of democratic norms and institutions in Hungary by Prime Minister Orbán and his far-right Fidesz party has caused alarm bells to ring in Brussels and through a number of European capitals (Foer 2019). Since taking office in 2010, Orbán has worked to curtail judicial independence, erode legislative constrains on the use of executive power, undermine political civil liberties, limit academic freedom, and constrain the ability of civil society organizations to work freely in Hungary. Indeed, the election and immediate actions of Orbán in 2010 pushed Hungary from a promising liberal democracy to an electoral democracy. And, according to V-Dem data, this downward trend has continued unabated for the past ten years.

In Benin, the government recently shut down the internet and cracked down on protest in the run-up to its elections in late April (Amnesty International 2019b, BBC 2019). Further, new election laws in Benin limited the ability of opposition parties to get on the ballet - both of the major parties on the April ballot were loyal the current regime. Moreover, President Talon's government has constrained political civil liberties, such as the right to protest, over the last year. Coupled with the fact that violence erupted 
after the recent election and that the government is failing to address concerns over the integrity of this election, it seems that Benin is creeping towards an adverse regime transition.

The above descriptions are not to say that any of these cases will, with certainty, experience an adverse regime transition in 2019 or 2020 only that the recent news coming out of these countries is not promising. That said, there are a few countries within the top 20 forecasts seem to be cases in which the current regime is influx; they are bouncing between RoW classes as their political institutions are at the border of different thresholds. As noted in the introduction, Albania is one of these cases; Mauritius and Fiji are others. However, while Albania and Mauritius are examples of a burgeoning liberal democracies that are struggling to solidify important liberalization reforms, Fiji is newly minted electoral democracy with a long history of democratic advancements followed closely by democratic erosion.

Within our sample, Fiji has experienced four ARTs (1987, 2000, 2007, and 2016). V-Dem data suggest that the ART in 2016 was a product of a slight decrease in the Electoral Democracy index. However, the three prior ARTs were all triggered by coups and crackdowns on civil liberties. And, while the military nominally relinquished control in 2015, they handed power over to Prime Minister Bainimarama, the head of the former military regime and leader of the Fiji First party, which is considered to be loyal to the military. In the 2018 elections, the Fiji First party saw its vote share decrease from 59.17 percent to 50.02 percent. Thus, there is concern that if support erodes further the military might again stage a coup.

\section{Conclusion}

This a paper introduces the V-Forecast project, the Varieties of Democracy Institute's forecasting intuitive. The goal of this project is to develop a suite of forecasting models focused specifically on democratic erosion and other phenomena related to democratic governance. The aim is to make these forecasts easy to understand, transparent in construction, and publicly available. The hope is that policy-makers, aid agencies, and nongovernmental organizations will find these tools useful, and direct resources to atrisk cases. Indeed, we hope that all relevant actors will use these tools to improve the conditions in troubled countries, making our predictions wrong.

Although the current approach and model seem to be working well, two limitations need to be highlighted. First, as the discussion above highlights, our current models perform remarkably well. However, since this is the first iteration of live forecasts where we predict into the actual future (as of the time the forecasts were created), these kinds of accuracy assessments have to be based on retrospective test forecasts. We have to pretend that we do not have information on ARTs and data which in fact we do already 
have. We did all this with the current, v9 version of V-Dem. The limitation in this, and something that we cannot accurately recreate, is that we do not know whether the underlying data will change as well.

During development of this forecasting system, which used both v8 and later v9 versions of $\mathrm{V}$-Dem, it became apparent that due to an adjustment in some of the data aggregations in V-Dem, and as well the inherent potential for retrospective changes in the estimated V-Dem measurement model, the set of ARTs changed slightly but substantially enough, given the nature of rare events, to negatively impact an attempt to assess v8 model and forecast performance with v9 outcome data. Essentially the target had shifted from under the forecast. This is an unavoidable possibility that we cannot address, but which could impact the future assessment of the current set of forecasts in early 2021.

The other limitation is due to the operationalization of ARTs with the categorical regime of the world indicator. We define an ART as a movement from a higher category to any lower category. Although conceptually ARTs should be significant movements of a regime towards increased authoritarianism, with our current operationalization we cannot distinguish these from instances where a country was already close to the next RoW category experienced a relatively small movement that pushed it across the category boundary. This means that some of the cases of ARTs identified in our data could be relatively small changes in one of the indicators used to construct the RoW categorization.

Moving forward, we plan to expand the scope of this project by developing a series of thematic forecasting models that can estimate the risk that there will be a significant decline in anyone of six dimensions of democracy: (1) elections, (2) civil society, (3) freedom of expression and media, (4) public corruption, (5) democratic inclusion, and (6) legislative and judicial constraints on the use of executive power. Further, we are going to develop a forecasting model that can estimate the risk of state-based electoral violence and intimidation.

By diversifying our forecast targets to include a number of different dimensions of democracy, we can provide policy-makers and aid agencies a suite tools for identifying which specific democratic institutions are at greater risk of erosion, so that they can direct resources accordingly. 


\section{References}

al Jazeera News Agency. (2019, April 22). Mali appoints new pm days after government resigns. https://www.aljazeera.com/news/2019/04/mali-pm-appointed -ogossagou-massacre-190422143413221.html. al Jazeera. (Accessed: April 30, 2019)

Amnesty International. (2019a). Amnesty international country report: Guatemala 2017/2018. https://www. amnesty.org/en/countries/americas/guatemala/ report-guatemala/. Amnesty International. (Accessed: April 30, 2019)

Amnesty International. (2019b, April 28). Benin: Internet shutdown on election day is a blunt attack on freedom of expression. https://www.amnesty.org/en/latest/news/ 2019/04/benin-internet-shutdown-on-election-day-is-a-blunt-attack/.

Amnesty International. (Accessed: April 30, 2019)

BBC. (2019, May 6). How benin's democratic crown has slipped. https://www.bbc.com/ news/world-africa-48150006. BBC. (Accessed: May 13, 2019)

Beger, A., Dorff, C. L., \& Ward, M. D. (2016). Irregular leadership changes in 2014: Forecasts using ensemble, split-population duration models. International Journal of Forecasting, 32(1), 98-111.

Bermeo, N. (2016). On democratic backsliding. Journal of Democracy, 27(1), 5-19.

Bowlsby, D., Chenoweth, E., Hendrix, C., \& Moyer, J. D. (2019). The future is a moving target: Predicting political instability. British Journal of Political Science, 1-13.

Brandt, P. T., Freeman, J. R., \& Schrodt, P. A. (2011). Real time, time series forecasting of inter- and intra-state political conflict. Conflict Management and Peace Science, $28(1), 41-64$.

Breiman, L. (1996). Bagging predictors. Machine Learning, 24(2), 123-140.

Breiman, L. (2001). Random forests. Machine Learning, 45(1), 5-32.

Cederman, L.-E., \& Weidmann, N. B. (2017). Predicting armed conflict: Time to adjust our expectations? Science, 355(6324), 474-476.

Coppedge, M. (2017). Eroding regimes: What, where, and when? V-Dem Working Paper, $5 \%$.

Coppedge, M., Gerring, J., Knutsen, C. H., Lindberg, S. I., Teorell, J., Altman, D., ... Ziblatt, D. (2019a). V-dem codebook v9. 
Coppedge, M., Gerring, J., Knutsen, C. H., Lindberg, S. I., Teorell, J., Altman, D., ... Ziblatt, D. (2019b). V-dem country-year dataset v9. Varieties of Democracy (V-Dem) Project. doi: https://doi.org/10.23696/vdemcy19

Diamond, L. (2015). Facing up to the democratic recession. Journal of Democracy, $26(1), 141-155$.

Eulich, W. (2019, May 10). Ahead of elections, guatemalas strides and setbacks in justice. https://www.csmonitor.com/World/Americas/2019/0510/Ahead -of-elections-Guatemala-s-strides-and-setbacks-in-justice. The Christian Science Monitor. (Accessed: May 13, 2019)

Foer, F. (2019, June). Viktor orbn's war on intellect. https://www.theatlantic.com/ magazine/archive/2019/06/george-soros-viktor-orban-ceu/588070/. The Atlantic. (Accessed: May 13, 2019)

Freund, Y., \& Schapire, R. E. (1997). A decision-theoretic generalization of on-line learning and an application to boosting. Journal of computer and system sciences, 55(1), 119-139.

Friedman, J. H. (2001). Greedy function approximation: A gradient boosting machine. Annals of statistics, 1189-1232.

Friedman, J. H. (2002). Stochastic gradient boosting. Computational Statistics \& Data Analysis, 38(4), 367-378.

Gleditsch, N. P., Wallensteen, P., Eriksson, M., Sollenberg, M., \& Strand, H. (2002). Armed conflict 1946-2001: A new dataset. Journal of Peace Research, 39(5), 615637.

Gohdes, A. R. (2019). Repression technology: Internet accessibility and state violence. American Journal of Political Science, Forthcoming, 1-13.

Goldsmith, B. E., \& Butcher, C. (2018). Genocide forecasting: Past accuracy and new forecasts to 2020. Journal of Genocide Research, 20(1), 90-107.

Goldsmith, B. E., Butcher, C. R., Semenovich, D., \& Sowmya, A. (2013). Forecasting the onset of genocide and politicide: Annual out-of-sample forecasts on a global dataset, 1988-2003. Journal of Peace Research, 50(4), 437-452.

Goldstone, J. A., Bates, R. H., Epstein, D. L., Gurr, T. R., Lustik, M. B., Marshall, M. G., ... Woodward, M. (2010). A global model for forecasting political instability. American Journal of Political Science, 54(1), 190-208. 
Hegre, H., Allansson, M., Basedau, M., Colaresi, M., Croicu, M., Fjelde, H., .. Vestby, J. (2019). Views: A political violence early-warning system. Journal of Peace Research, $56(2), 155-174$.

Hegre, H., Karlsen, J., Nygård, H. M., Strand, H., \& Urdal, H. (2013). Predicting armed conflict, 2010-2050. International Studies Quarterly, 57(2), 250-270.

Hill, D. W., \& Jones, Z. M. (2014). An empirical evaluation of explanations for state repression. American Political Science Review, 108(3), 661-687.

Ho, T. K. (1995). Random decision forests. In Proceedings of 3rd international conference on document analysis and recognition (Vol. 1, pp. 278-282).

Ho, T. K. (1998). The random subspace method for constructing decision forests. IEEE Transactions on Pattern Analysis and Machine Intelligence, 20(8).

Kishi, R., \& Raleigh, C. (2019, May 5). Midterm elections in the philippines: Power consolidation at its finest. https://www . acleddata.com/2019/05/10/midterm -elections-in-the-philippines-power-consolidation-at-its-finest/. Armed Conflict Location Event Dataset (ACLED). (Accessed: May 13, 2019)

Kurlantzick, J. (2013). Democracy in retreat: The revolt of the middle class and the worldwide decline of representative government. Yale University Press.

Laurent, H., \& Rivest, R. L. (1976). Constructing optimal binary decision trees is npcomplete. Information processing letters, 5(1), 15-17.

Levitsky, S., \& Ziblatt, D. (2018). How democracies die. Broadway Books.

Lindberg, S. I., Coppedge, M., Gerring, J., \& Teorell, J. (2014). V-dem: A new way to measure democracy. Journal of Democracy, 25(3), 159-169.

Lührmann, A., Dahlum, S., Lindberg, S. I., Maxwell, L., Mechkova, V., Olin, M., ... Stepanova, N. (2018). V-dem annual democracy report 2018: Democracy for all? https://www.v-dem.net/media/filer \_public/68/51/685150f0-47e1-4d03 -97bc-45609c3f158d/v-dem\_annual\_dem\_report\_2018.pdf.

Lührmann, A., \& Lindberg, S. I. (2019). A third wave of autocratization is here: What is new about it? Democratization, 1-19.

Lührmann, A., Mechkova, V., Dahlum, S., Maxwell, L., Olin, M., Petrarca, C. S., ... Lindberg, S. I. (2018). State of the world 2017: Autocratization and exclusion? Democratization, 25(8), 1321-1340. 
Lührmann, A., Tannenberg, M., \& Lindberg, S. I. (2018). Regimes of the world (row): Opening new avenues for the comparative study of political regimes. Politics \& Governance, $6(1)$.

Mason, L., Baxter, J., Bartlett, P. L., \& Frean, M. R. (2000). Boosting algorithms as gradient descent. In Advances in neural information processing systems (pp. 512-518).

Mechkova, V., Lührmann, A., \& Lindberg, S. I. (2017). How much democratic backsliding? Journal of Democracy, 28(4), 162-169.

Pettersson, T., \& Eck, K. (2018). Organized violence, 1989-2017. Journal of Peace Research, 55(4), 535-547.

Powell, J. M., \& Thyne, C. L. (2011). Global instances of coups from 1950 to 2010: A new dataset. Journal of Peace Research, 48(2), 249-259.

Quashie-Idun, S., \& Swails, B. (2019, April 19). Mali's prime minister and his entire government resign. https://edition.cnn.com/2019/04/19/africa/mali-government -resigns-intl/index.html. CNN online. (Accessed: April 30, 2019)

Quinlan, J. R. (1979). Discovering rules by induction from large collections of examples. Expert Systems in the Micro Electronics Age.

Quinlan, J. R. (1986). Induction of decision trees. Machine Learning, 1(1), 81-106.

Quinlan, J. R. (1987). Simplifying decision trees. International Journal of Man-Machine Studies, $27(3), 221-234$.

Rivest, R. L. (1987). Learning decision lists. Machine Learning, 2(3), 229-246.

Rokach, L. (2016). Decision forest: Twenty years of research. Information Fusion, 27, $111-125$.

Schmidt, S. (2017, November 14). Trump chuckled as duterte called journalists 'spies.' that's no joke in the philippines. https://www. washingtonpost.com/news/ morning-mix/wp/2017/11/14/trump-chuckled-as-duterte-called-journalists -spies-thats-no-laughing-matter-in-the-philippines/. The Washington Post. (Accessed: April 15, 2019)

Schrodt, P. A. (2014). Seven deadly sins of contemporary quantitative political analysis. Journal of Peace Research, 51(2), 287-300.

Soyer, E., \& Hogarth, R. M. (2012). The illusion of predictability: How regression statistics mislead experts. International Journal of Forecasting, 28(3), 695-711. 
Vogt, M., Bormann, N.-C., Rüegger, S., Cederman, L.-E., Hunziker, P., \& Girardin, L. (2015). Integrating data on ethnicity, geography, and conflict: The ethnic power relations data set family. Journal of Conflict Resolution, 59(7), 1327-1342.

Ward, M. D., \& Beger, A. (2017). Lessons from near real-time forecasting of irregular leadership changes. Journal of Peace Research, 54 (2), 141-156.

Ward, M. D., Greenhill, B. D., \& Bakke, K. M. (2010). The perils of policy by p-value: Predicting civil conflicts. Journal of Peace Research, 47(4), 363-375.

Woocher, L., Zapata, M., Valentino, B., \& Hazlett, C. (2018). Early warning project. https://earlywarningproject.ushmm.org/.

Wu, X., Kumar, V., Quinlan, J. R., Ghosh, J., Yang, Q., Motoda, H., .. others (2008). Top 10 algorithms in data mining. Knowledge and Information Systems, 14(1), 1-37.

Zou, H., \& Hastie, T. (2005). Regularization and variable selection via the elastic net. Journal of the Royal Statistical Society: Series B (Statistical Methodology), 67(2), $301-320$. 


\section{A Appendix: List of 2019-2020 forecasts for the risk of ART}

Table 7: List of complete 2019-2020 ART risk forecasts

\begin{tabular}{|c|c|c|c|c|}
\hline & $\begin{array}{l}\text { Country } \\
\text { Name }\end{array}$ & $\begin{array}{l}\text { Estimated } \\
\text { Risk }\end{array}$ & $\begin{array}{l}\text { RoW } \\
\text { Classification }\end{array}$ & $\begin{array}{r}\text { Year since } \\
\text { last ART }\end{array}$ \\
\hline 1 & Philippines & 0.460 & Electoral Democracy & 14 \\
\hline 2 & Fiji & 0.265 & Electoral Democracy & 2 \\
\hline 3 & Mali & 0.254 & Electoral Democracy & 6 \\
\hline 4 & Hungary & 0.250 & Electoral Democracy & 8 \\
\hline 5 & Guatemala & 0.249 & Electoral Democracy & 35 \\
\hline 6 & Kosovo & 0.228 & Electoral Democracy & 6 \\
\hline 7 & Kyrgyzstan & 0.217 & Electoral Democracy & 2 \\
\hline 8 & Moldova & 0.200 & Electoral Democracy & 10 \\
\hline 9 & Bosnia and Herzegovina & 0.193 & Electoral Democracy & 26 \\
\hline 10 & Tanzania & 0.182 & Electoral Democracy & 2 \\
\hline 11 & Albania & 0.170 & Liberal Democracy & 1 \\
\hline 12 & Benin & 0.164 & Liberal Democracy & 3 \\
\hline 13 & The Gambia & 0.143 & Electoral Democracy & 23 \\
\hline 14 & Czech Republic & 0.129 & Liberal Democracy & 79 \\
\hline 15 & Italy & 0.126 & Liberal Democracy & 94 \\
\hline 16 & Nicaragua & 0.122 & Electoral Autocracy & 11 \\
\hline 17 & Mauritius & 0.120 & Liberal Democracy & 1 \\
\hline 18 & Slovenia & 0.115 & Liberal Democracy & 29 \\
\hline 19 & Turkmenistan & 0.106 & Electoral Autocracy & 6 \\
\hline 20 & Ghana & 0.106 & Liberal Democracy & 3 \\
\hline 21 & Comoros & 0.104 & Electoral Autocracy & 3 \\
\hline 22 & Israel & 0.103 & Liberal Democracy & 8 \\
\hline 23 & Niger & 0.100 & Electoral Democracy & 8 \\
\hline 24 & Colombia & 0.098 & Electoral Democracy & 34 \\
\hline 25 & France & 0.096 & Liberal Democracy & 78 \\
\hline 26 & Lesotho & 0.094 & Electoral Democracy & 1 \\
\hline 27 & Haiti & 0.092 & Electoral Autocracy & 13 \\
\hline 28 & Armenia & 0.091 & Electoral Autocracy & 23 \\
\hline 29 & Barbados & 0.090 & Liberal Democracy & 118 \\
\hline
\end{tabular}


Table 7: List of complete 2019-2020 ART risk forecasts (continued)

\begin{tabular}{|c|c|c|c|c|}
\hline & $\begin{array}{l}\text { Country } \\
\text { Name }\end{array}$ & $\begin{array}{l}\text { Estimated } \\
\text { Risk }\end{array}$ & $\begin{array}{l}\text { RoW } \\
\text { Classification }\end{array}$ & $\begin{array}{r}\text { Year since } \\
\text { last ART }\end{array}$ \\
\hline 30 & Romania & 0.086 & Electoral Democracy & 118 \\
\hline 31 & Tunisia & 0.085 & Electoral Democracy & 0 \\
\hline 32 & Somalia & 0.085 & Closed Autocracy & 34 \\
\hline 33 & Latvia & 0.084 & Liberal Democracy & 29 \\
\hline 34 & Afghanistan & 0.082 & Electoral Autocracy & 44 \\
\hline 35 & Chile & 0.080 & Electoral Democracy & 0 \\
\hline 36 & Burundi & 0.077 & Electoral Autocracy & 22 \\
\hline 37 & Nepal & 0.075 & Electoral Democracy & 6 \\
\hline 38 & Pakistan & 0.074 & Electoral Autocracy & 5 \\
\hline 39 & Guinea-Bissau & 0.074 & Electoral Autocracy & 0 \\
\hline 40 & Togo & 0.074 & Electoral Autocracy & 1 \\
\hline 41 & Bhutan & 0.073 & Liberal Democracy & 118 \\
\hline 42 & Greece & 0.071 & Electoral Democracy & 0 \\
\hline 43 & Kenya & 0.071 & Electoral Autocracy & 1 \\
\hline 44 & Lebanon & 0.070 & Electoral Autocracy & 0 \\
\hline 45 & Macedonia & 0.069 & Electoral Democracy & 6 \\
\hline 46 & Venezuela & 0.069 & Electoral Autocracy & 12 \\
\hline 47 & Namibia & 0.069 & Electoral Democracy & 1 \\
\hline 48 & Central African Republic & 0.069 & Electoral Autocracy & 14 \\
\hline 49 & Zimbabwe & 0.068 & Electoral Autocracy & 40 \\
\hline 50 & Costa Rica & 0.068 & Liberal Democracy & 69 \\
\hline 51 & Timor-Leste & 0.067 & Electoral Democracy & 118 \\
\hline 52 & Georgia & 0.065 & Electoral Democracy & 28 \\
\hline 53 & Sudan & 0.064 & Electoral Autocracy & 28 \\
\hline 54 & Poland & 0.063 & Electoral Democracy & 3 \\
\hline 55 & Liberia & 0.063 & Electoral Democracy & 14 \\
\hline 56 & Madagascar & 0.063 & Electoral Autocracy & 8 \\
\hline 57 & Guinea & 0.062 & Electoral Autocracy & 9 \\
\hline 58 & Burkina Faso & 0.062 & Electoral Democracy & 3 \\
\hline 59 & Malaysia & 0.062 & Electoral Autocracy & 48 \\
\hline 60 & Malawi & 0.061 & Electoral Democracy & 14 \\
\hline 61 & Uruguay & 0.060 & Liberal Democracy & 45 \\
\hline
\end{tabular}


Table 7: List of complete 2019-2020 ART risk forecasts (continued)

\begin{tabular}{|c|c|c|c|c|}
\hline & $\begin{array}{l}\text { Country } \\
\text { Name }\end{array}$ & $\begin{array}{l}\text { Estimated } \\
\text { Risk }\end{array}$ & $\begin{array}{l}\text { RoW } \\
\text { Classification }\end{array}$ & $\begin{array}{l}\text { Year since } \\
\text { last ART }\end{array}$ \\
\hline 62 & Montenegro & 0.060 & Electoral Autocracy & 2 \\
\hline 63 & South Korea & 0.060 & Electoral Democracy & 0 \\
\hline 64 & El Salvador & 0.056 & Electoral Democracy & 21 \\
\hline 65 & India & 0.056 & Electoral Democracy & 43 \\
\hline 66 & Gabon & 0.056 & Electoral Autocracy & 53 \\
\hline 67 & Ivory Coast & 0.056 & Electoral Democracy & 4 \\
\hline 68 & Bolivia & 0.055 & Electoral Democracy & 37 \\
\hline 69 & Bangladesh & 0.055 & Electoral Autocracy & 6 \\
\hline 70 & Paraguay & 0.054 & Electoral Democracy & 70 \\
\hline 71 & Burma/Myanmar & 0.054 & Electoral Autocracy & 56 \\
\hline 72 & Cape Verde & 0.052 & Electoral Democracy & 0 \\
\hline 73 & Uganda & 0.049 & Electoral Autocracy & 24 \\
\hline 74 & Suriname & 0.049 & Electoral Democracy & 38 \\
\hline 75 & Mozambique & 0.047 & Electoral Autocracy & 44 \\
\hline 76 & Sri Lanka & 0.047 & Electoral Democracy & 13 \\
\hline 77 & Nigeria & 0.047 & Electoral Democracy & 15 \\
\hline 78 & Sierra Leone & 0.047 & Electoral Democracy & 20 \\
\hline 79 & Turkey & 0.047 & Electoral Autocracy & 5 \\
\hline 80 & Indonesia & 0.046 & Electoral Democracy & 57 \\
\hline 81 & Trinidad and Tobago & 0.044 & Liberal Democracy & 118 \\
\hline 82 & Serbia & 0.044 & Electoral Autocracy & 3 \\
\hline 83 & Iran & 0.043 & Electoral Autocracy & 118 \\
\hline 84 & Mauritania & 0.042 & Electoral Autocracy & 10 \\
\hline 85 & Maldives & 0.042 & Electoral Autocracy & 5 \\
\hline 86 & Cameroon & 0.042 & Electoral Autocracy & 57 \\
\hline 87 & Democratic Republic of the Congo & 0.041 & Electoral Autocracy & 53 \\
\hline 88 & South Africa & 0.041 & Electoral Democracy & 5 \\
\hline 89 & Panama & 0.041 & Electoral Democracy & 49 \\
\hline 90 & Botswana & 0.041 & Electoral Democracy & 1 \\
\hline 91 & Chad & 0.040 & Electoral Autocracy & 49 \\
\hline 92 & Ecuador & 0.040 & Electoral Democracy & 46 \\
\hline 93 & Singapore & 0.040 & Electoral Autocracy & 118 \\
\hline
\end{tabular}


Table 7: List of complete 2019-2020 ART risk forecasts (continued)

\begin{tabular}{|c|c|c|c|c|}
\hline & $\begin{array}{l}\text { Country } \\
\text { Name }\end{array}$ & $\begin{array}{l}\text { Estimated } \\
\text { Risk }\end{array}$ & $\begin{array}{l}\text { RoW } \\
\text { Classification }\end{array}$ & $\begin{array}{l}\text { Year since } \\
\text { last ART }\end{array}$ \\
\hline 94 & Peru & 0.039 & Electoral Democracy & 26 \\
\hline 95 & Ukraine & 0.039 & Electoral Autocracy & 6 \\
\hline 96 & Brazil & 0.038 & Electoral Democracy & 53 \\
\hline 97 & Azerbaijan & 0.038 & Electoral Autocracy & 28 \\
\hline 98 & Solomon Islands & 0.038 & Electoral Democracy & 12 \\
\hline 99 & Guyana & 0.038 & Electoral Democracy & 118 \\
\hline 100 & Libya & 0.038 & Closed Autocracy & 4 \\
\hline 101 & Iraq & 0.037 & Electoral Autocracy & 8 \\
\hline 102 & Croatia & 0.037 & Electoral Democracy & 19 \\
\hline 103 & Tajikistan & 0.037 & Electoral Autocracy & 28 \\
\hline 104 & Lithuania & 0.037 & Electoral Democracy & 2 \\
\hline 105 & Honduras & 0.037 & Electoral Autocracy & 9 \\
\hline 106 & Ethiopia & 0.036 & Electoral Autocracy & 118 \\
\hline 107 & Mexico & 0.036 & Electoral Democracy & 118 \\
\hline 108 & Slovakia & 0.036 & Electoral Democracy & 5 \\
\hline 109 & Papua New Guinea & 0.035 & Electoral Autocracy & 26 \\
\hline 110 & Kazakhstan & 0.034 & Electoral Autocracy & 28 \\
\hline 111 & Dominican Republic & 0.034 & Electoral Democracy & 28 \\
\hline 112 & Republic of the Congo & 0.033 & Electoral Autocracy & 21 \\
\hline 113 & Vietnam & 0.032 & Closed Autocracy & 2 \\
\hline 114 & Zambia & 0.032 & Electoral Autocracy & 3 \\
\hline 115 & Bulgaria & 0.032 & Electoral Democracy & 69 \\
\hline 116 & Senegal & 0.031 & Electoral Democracy & 36 \\
\hline 117 & Cyprus & 0.030 & Liberal Democracy & 49 \\
\hline 118 & Egypt & 0.029 & Electoral Autocracy & 5 \\
\hline 119 & Morocco & 0.029 & Closed Autocracy & 118 \\
\hline 120 & Angola & 0.029 & Electoral Autocracy & 25 \\
\hline 121 & Finland & 0.028 & Liberal Democracy & 118 \\
\hline 122 & Mongolia & 0.027 & Electoral Democracy & 107 \\
\hline 123 & Jamaica & 0.026 & Electoral Democracy & 37 \\
\hline 124 & Equatorial Guinea & 0.025 & Electoral Autocracy & 39 \\
\hline 125 & United States of America & 0.025 & Liberal Democracy & 118 \\
\hline
\end{tabular}


Table 7: List of complete 2019-2020 ART risk forecasts (continued)

\begin{tabular}{|c|c|c|c|c|}
\hline & Country & Estimated & RoW & Year since \\
\hline & Name & Risk & Classification & last ART \\
\hline 126 & Sweden & 0.024 & Liberal Democracy & 118 \\
\hline 127 & Austria & 0.024 & Liberal Democracy & 84 \\
\hline 128 & Taiwan & 0.023 & Liberal Democracy & 8 \\
\hline 129 & Rwanda & 0.023 & Electoral Autocracy & 44 \\
\hline 130 & Argentina & 0.022 & Electoral Democracy & 41 \\
\hline 131 & Cambodia & 0.022 & Electoral Autocracy & 45 \\
\hline 132 & Belarus & 0.022 & Electoral Autocracy & 21 \\
\hline 133 & New Zealand & 0.021 & Liberal Democracy & 118 \\
\hline 134 & South Sudan & 0.021 & Closed Autocracy & 7 \\
\hline 135 & Canada & 0.020 & Liberal Democracy & 118 \\
\hline 136 & Djibouti & 0.020 & Electoral Autocracy & 36 \\
\hline 137 & Portugal & 0.020 & Liberal Democracy & 57 \\
\hline 138 & Estonia & 0.019 & Liberal Democracy & 26 \\
\hline 139 & Ireland & 0.017 & Liberal Democracy & 99 \\
\hline 140 & Russia & 0.017 & Electoral Autocracy & 22 \\
\hline 141 & United Kingdom & 0.016 & Liberal Democracy & 118 \\
\hline 142 & Japan & 0.015 & Liberal Democracy & 118 \\
\hline 143 & Algeria & 0.015 & Electoral Autocracy & 52 \\
\hline 144 & Thailand & 0.013 & Closed Autocracy & 4 \\
\hline 145 & Belgium & 0.013 & Liberal Democracy & 78 \\
\hline 146 & Netherlands & 0.012 & Liberal Democracy & 78 \\
\hline 147 & Qatar & 0.012 & Closed Autocracy & 118 \\
\hline 148 & Spain & 0.011 & Liberal Democracy & 79 \\
\hline 149 & Swaziland & 0.011 & Closed Autocracy & 118 \\
\hline 150 & Iceland & 0.011 & Liberal Democracy & 88 \\
\hline 151 & North Korea & 0.011 & Closed Autocracy & 73 \\
\hline 152 & Germany & 0.010 & Liberal Democracy & 84 \\
\hline 153 & Jordan & 0.010 & Closed Autocracy & 65 \\
\hline 154 & Norway & 0.010 & Liberal Democracy & 76 \\
\hline 155 & Switzerland & 0.010 & Liberal Democracy & 118 \\
\hline 156 & Denmark & 0.010 & Liberal Democracy & 75 \\
\hline 157 & Australia & 0.009 & Liberal Democracy & 102 \\
\hline
\end{tabular}


Table 7: List of complete 2019-2020 ART risk forecasts (continued)

\begin{tabular}{llllr}
\hline & Country & Estimated & RoW & Year since \\
& Name & Risk & Classification & last ART \\
\hline 158 & Uzbekistan & 0.009 & Closed Autocracy & 27 \\
159 & Yemen & 0.009 & Closed Autocracy & 2 \\
160 & Eritrea & 0.007 & Closed Autocracy & 118 \\
161 & Cuba & 0.007 & Closed Autocracy & 58 \\
162 & Laos & 0.006 & Closed Autocracy & 27 \\
163 & Kuwait & 0.006 & Closed Autocracy & 118 \\
164 & Oman & 0.006 & Closed Autocracy & 118 \\
165 & Syria & 0.006 & Closed Autocracy & 5 \\
166 & Luxembourg & 0.006 & Liberal Democracy & 78 \\
167 & China & 0.005 & Closed Autocracy & 97 \\
168 & United Arab Emirates & 0.004 & Closed Autocracy & 47 \\
169 & Saudi Arabia & 0.003 & Closed Autocracy & 49 \\
\hline
\end{tabular}

\section{B Appendix: Nontechnical overview of machine learn- ing methods}

For our unweighted model average ensemble, we use the estimates from three machine learning models: logit with elastic-net regularization, random forest, and gradient boosted forest. As their names imply, logit with elastic-net regularization models are built around maximum-likelihood principles, while random forest and gradient boosted forest start with decision trees. Below, we provide an overview of these machines learning methods.

Logit w/elastic-net regulation: Like standard logistic regression, the elastic-net regularization (ENR) version estimates coefficients for a linear equation relating input covariates to the binary outcome variable through a logistic function. In addition to the regular logistic likelihood, the cost function for elastic net regression includes a penalty term for non-zero coefficient values. This penalty term is governed by two hyperparameters and has the practical effect of pushing some coefficient estimates completely to zero, and shrinking the remaining coefficient estimates towards zero.

The ENR model works well with variables that are highly correlated (provides different weights to highly correlated variables according to how much variation the variable explains, allowing uninformative variables to go to zero), helps reduce model-fit (introduces bias to the training model in order to produce more accurate out-of-sample predictions), and provides a heuristic for variable selection (orders variables according to post-weighted 
parameter estimates and identifies which parameter went to zero). Introduced by Zou \& Hastie (2005), this algorithm has become a mainstay in the machine learning discipline. Within the social sciences, the Early Warning Project uses this method to forecast mass killings (Woocher et al. 2018).

Random Forest \& Gradient Boosted Forest: Decision trees are at the root of both the random forest and gradient boosted forest algorithms. Decision tree algorithms start by measuring how well each variable, at different cut-points, classifies observations according to the outcome variable, selecting the cut-point that performs best. The algorithm does this for all variables and determines which variable, and at what cut-point, best explains the outcome variable. This variable becomes a root node. The algorithm splits all of the observations according to the root node cut-point, branching out to create two (or more) sub-nodes. At each sub-node, the algorithm again assesses which of the remaining variables, and at what value, best classifies the data in each sub-node. It repeats this process to the point in which new nodes (splits) no longer improve classification.

With their introduction and formalization by Quinlan (1979), decision tree-based approaches serve as the foundation of many modern machine learning algorithms (Laurent \& Rivest 1976, Quinlan 1986, 1987, Rivest 1987, Rokach 2016). However, while decision trees do well at describing the data at hand, overfitting reduces their out-of-sample accuracy.

First introduced by Ho $(1995,1998)$ and extended by Breiman $(2001)$, the random forest (RF) algorithm helps address this overfitting issue. To do so, the RF algorithm introduces two randomization techniques. First, it draws a bootstrapped (with replacement) dataset and grows a decision tree. However, rather than assessing how well all variables perform at each node, the $\mathrm{RF}$ algorithm randomly selects $m$ number of variables for consideration. It repeats this process hundreds of times, growing a forest of diverse decision trees, each with a unique set of variables at each node. The observations excluded from the bootstrapped sample are fed into each randomized tree for classification. The algorithm calculates the average classification from these trees and records it as the probability the observation belongs in a specific class, whether there was an adverse regime transition, for example. These predictions are then compared to the observed value of the outcome variable.

Introduced by Breiman (1996), this bootstrap aggregation process (also known as "bagging") reduces issues related to model fit as well as a model's variance - how far the predicted value deviates from the observed value. This out-of-sample error (the mean prediction error) is an important metric for model tuning - determining the optimum number of variables, $m$, to use as well as the number of trees to grow. Since its introduction, the RF method has quickly become one of the most widely used machine learning algorithms (Rokach 2016). This is one of the primary methods Hegre et al. (2019) at the 
ViEWS project use to predict various types of political violence.

Like the RF algorithm, the gradient boosted forest (GBF) algorithm first draws a bootstrapped sample (with replacement) and grows a decision tree. Unlike the RF method that builds and combines a forest of randomly different trees in parallel, the GBF algorithm builds a series of trees, where each successive tree is trained so that it attempts to reduce the predictive error of the previous trees. Further, while the RF algorithm grows trees using $m$ number of variables at each node, the GBF method uses the entire variable set at each node split. However, it restricts the number of nodes (splits) within each decision tree, usually between one and ten nodes, growing what researchers refer to as "weak learners" or "shallow trees." The algorithm calculates the residuals using the bootstrapped data. It then fits another shallow tree to these residuals. The algorithm combines the two decision trees, runs the observed data through this ensemble of trees, calculates the residuals, and fits a new tree to these residuals. It then combines this tree with the others, repeating this recursive learning process hundreds of times, growing a forest of dependent decision trees. Thus, the GBF method has four parameters that affect the model's performance: the number of trees to grow, the number of nodes to allow, and two parameters that regulate how much each successive tree should "learn" (Rokach 2016).

The gradient boosted method was first introduced in the late 1990's and early 2000's as a way to improve the predictive (and classification) power of other decision tree models (Freund \& Schapire 1997, Friedman 2001, 2002, Mason et al. 2000, Rokach 2016). This method has grown in use throughout other disciplines; in fact, Wu et al. (2008) regard model boosting algorithms to be one of the top-ten tools for practical machine learning problems. Nevertheless, while Gohdes (2019) uses the GBF method for a classification problem looking at the relationship between internet accessibility and the type and target of political violence in Syria, to our knowledge, we are the first to adapt this approach to a forecasting problem centered around distinct political phenomenon.

Tuning of Model Hyperparameters: We optimized the hyperparameters for all of our machine learning models to maximize out-of-sample fit, with estimates obtained through a model tuning cross-validation procedure. Note that this cross-validation is nested within the top-level $2 \times 7$-fold cross-validation scheme we use to assess out-ofsample fit and model evaluation. In short, for each iteration of the top-level crossvalidation, we take the current training data set and perform an additional round of model-level cross-validation in order to optimize the hyperparameters. 


\section{Appendix: Performance for ensemble sub-models}

\section{C.1 Yearly test forecasts}

The plots below help provide a sense of how well each of our models are preforming across a series of yearly test forecasts (2011-17). Throughout these plots, light purple denotes country-year observations without an ART, blue denotes an observation that experienced an ART in the first year of the two-year window, while dark purple denotes observations with an ART in the last year of the two-year window. For example, the figure below shows the risk estimates our ensemble model generated for 2011-12. After training the model with data from 1970 to 2009, we use data from 2010 to calculate the country-level risk of ARTs for 2011-12.

Figure 6: Ensemble: 2011-2012 Test Forecast
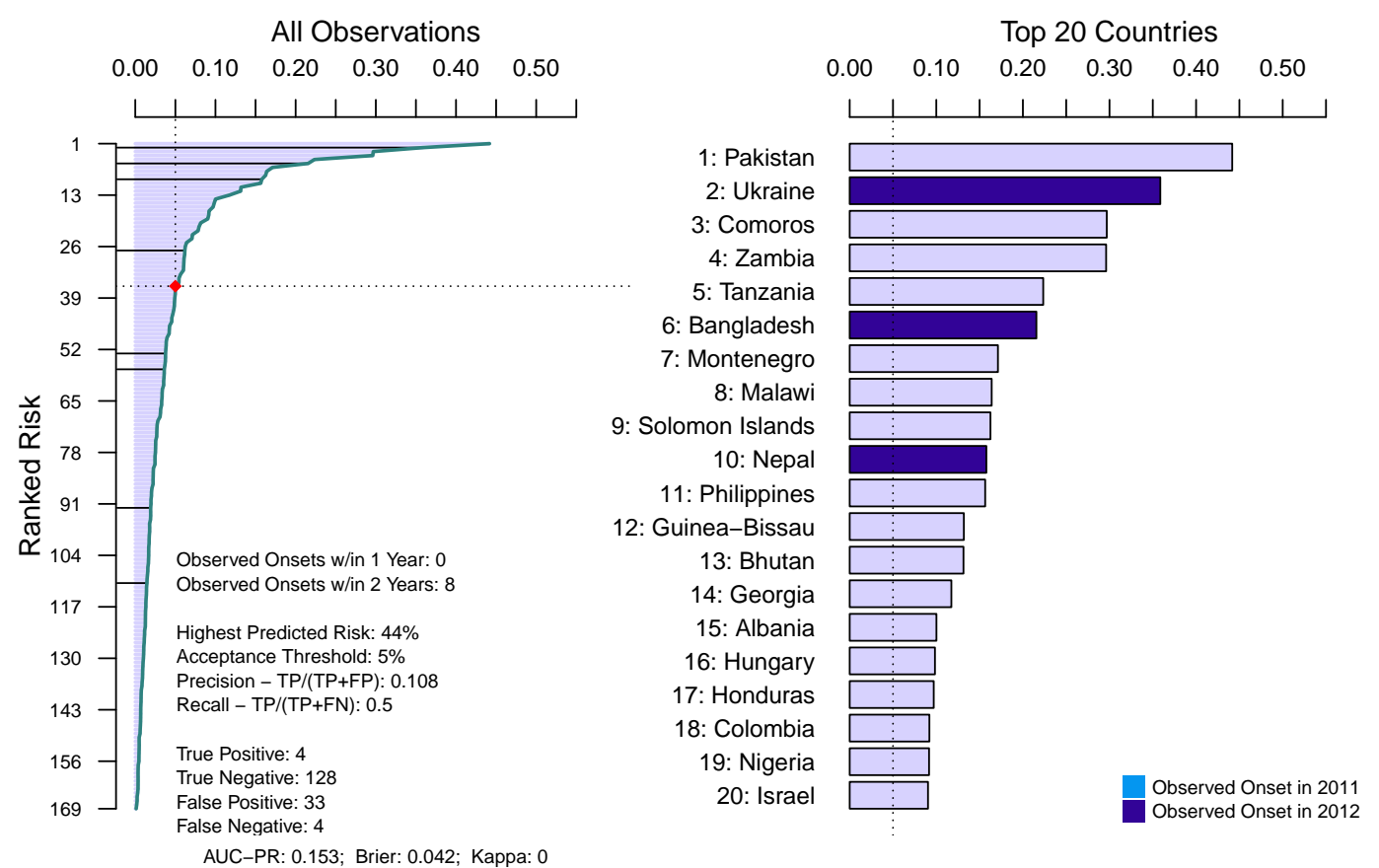

AUC-PR: 0.153; Brier: 0.042; Kappa: 0 
Figure 7: Ensemble: 2012-2013 Test Forecast
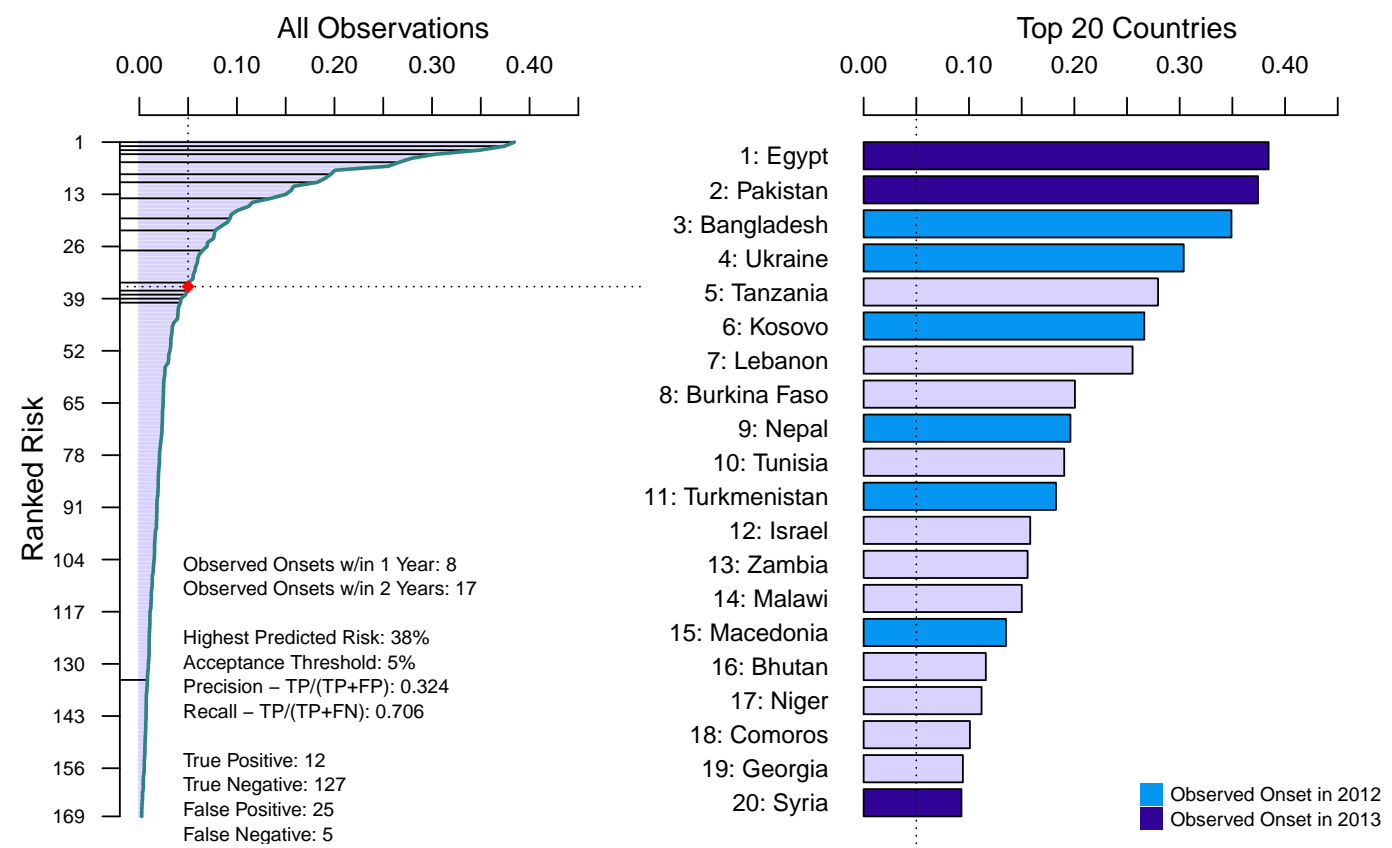

AUC-PR: 0.513; Brier: 0.076; Kappa: 0

Figure 8: Ensemble: 2013-2014 Test Forecast
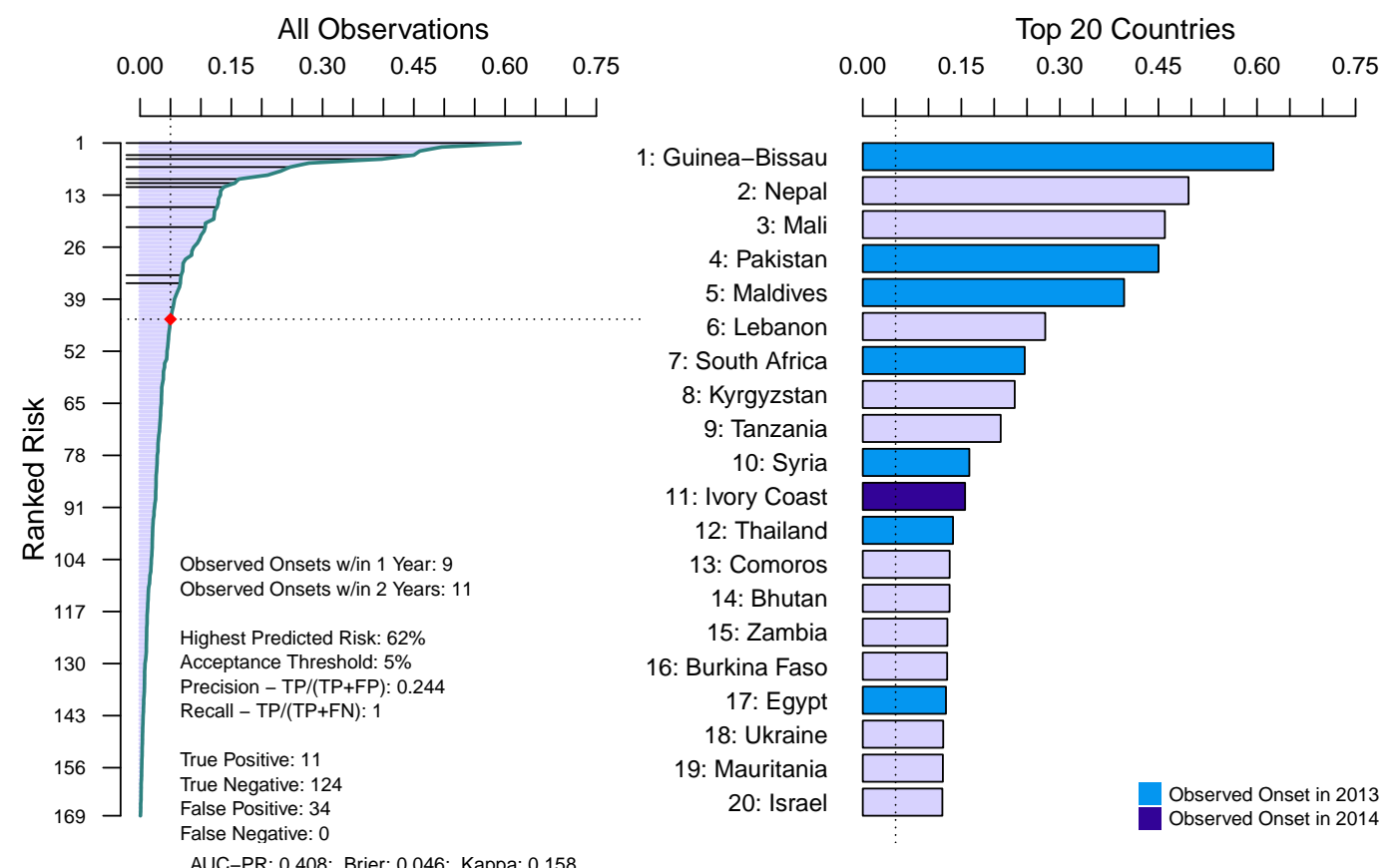

AUC-PR: 0.408; Brier: 0.046; Kappa: 0.158 
Figure 9: Ensemble: 2014-2015 Test Forecast
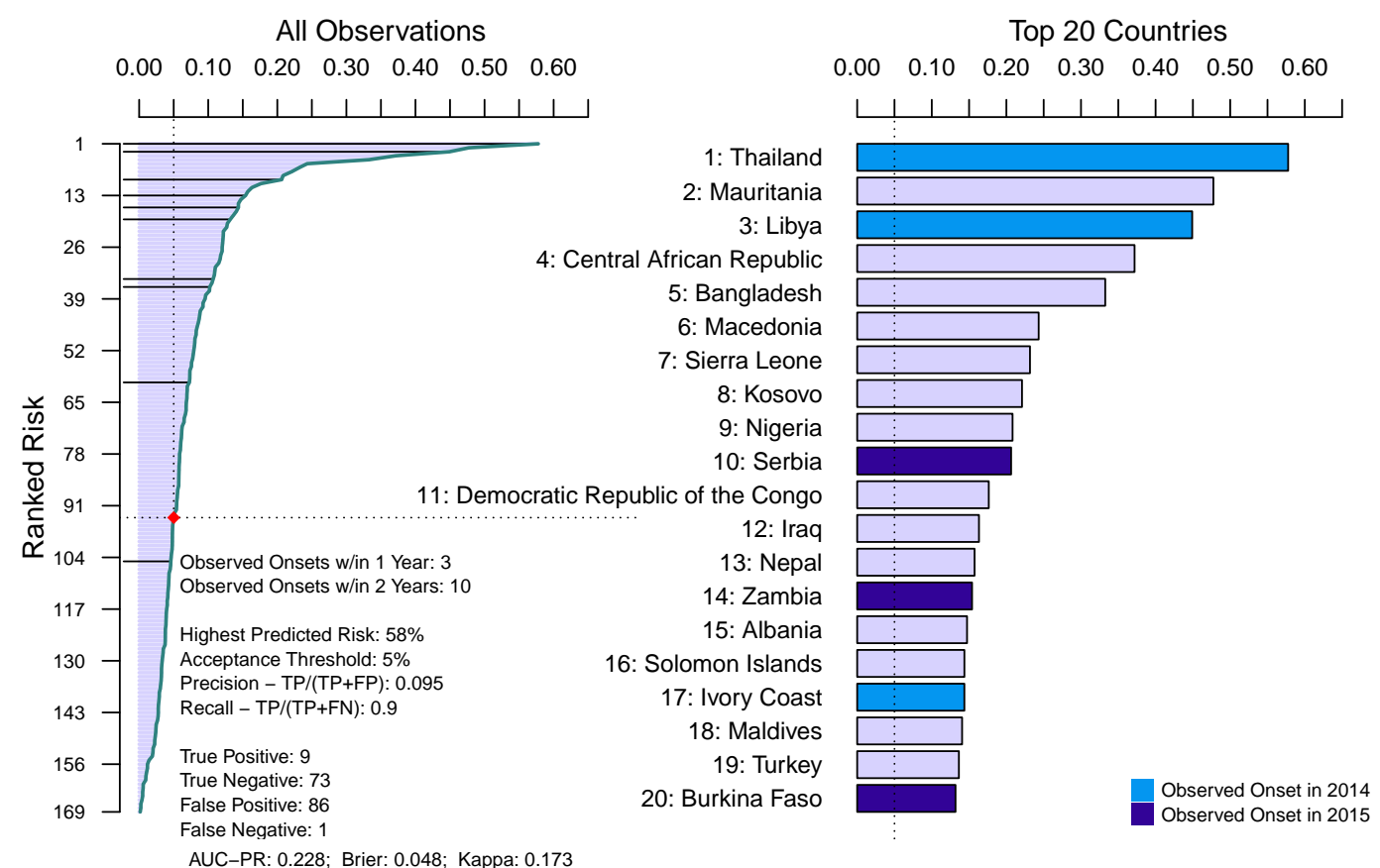

AUC-PR: 0.228; Brier: 0.048; Kappa: 0.173

Figure 10: Ensemble: 2015-2016 Test Forecast
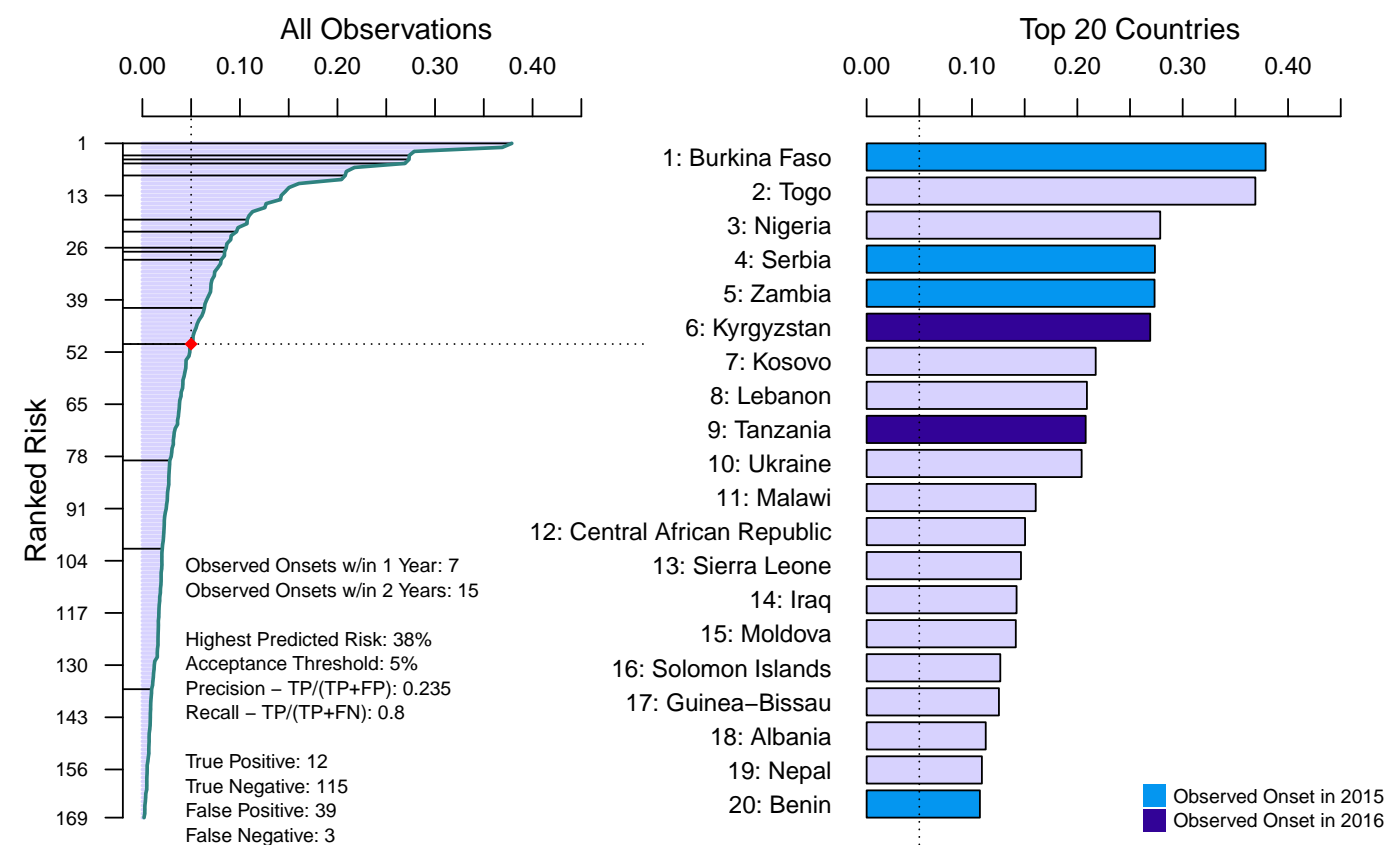

AUC-PR: 0.299; Brier: 0.072; Kappa: 0 
Figure 11: Ensemble: 2016-2017 Test Forecast
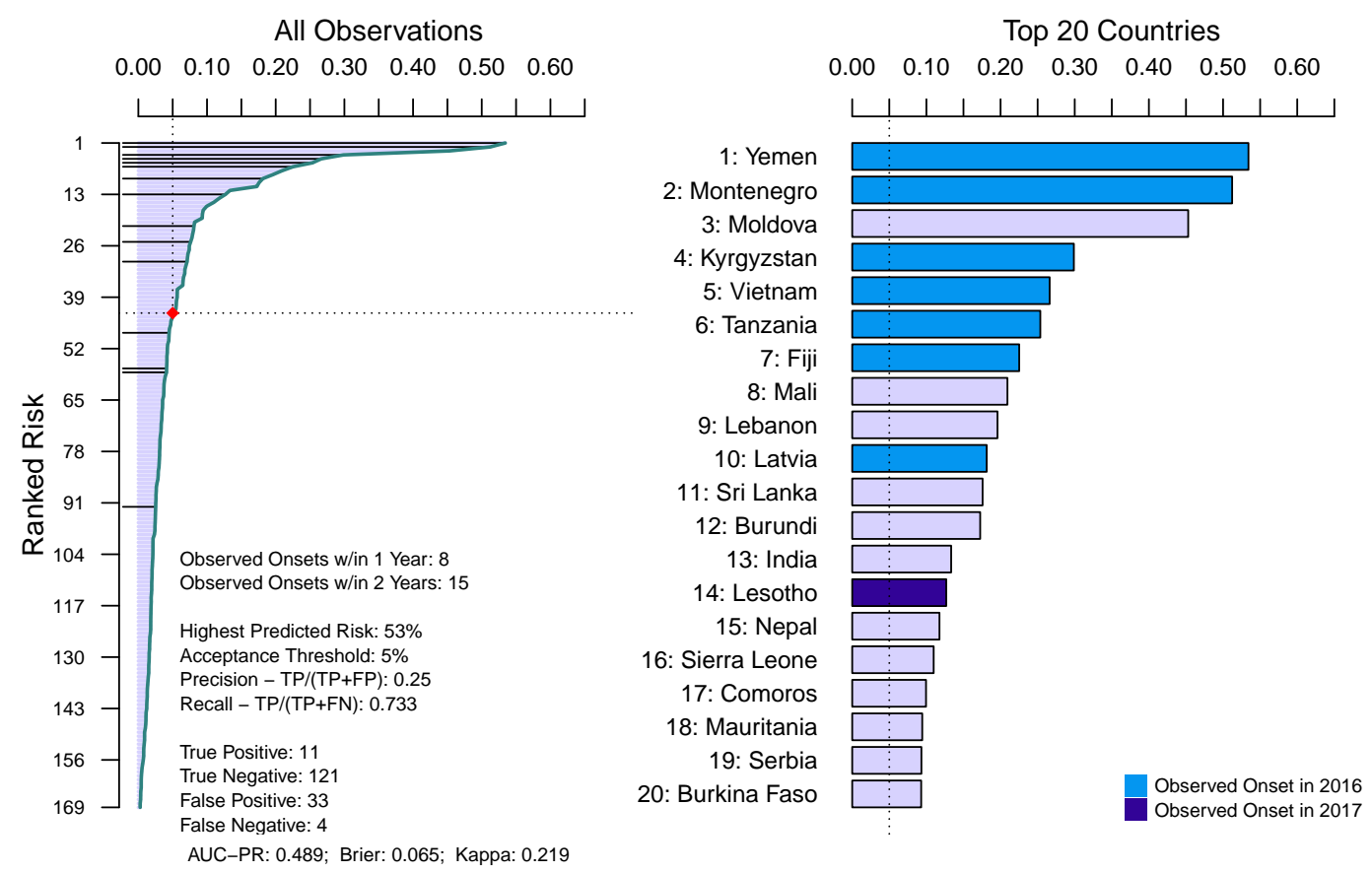

Figure 12: Ensemble: 2017-2018 Test Forecast
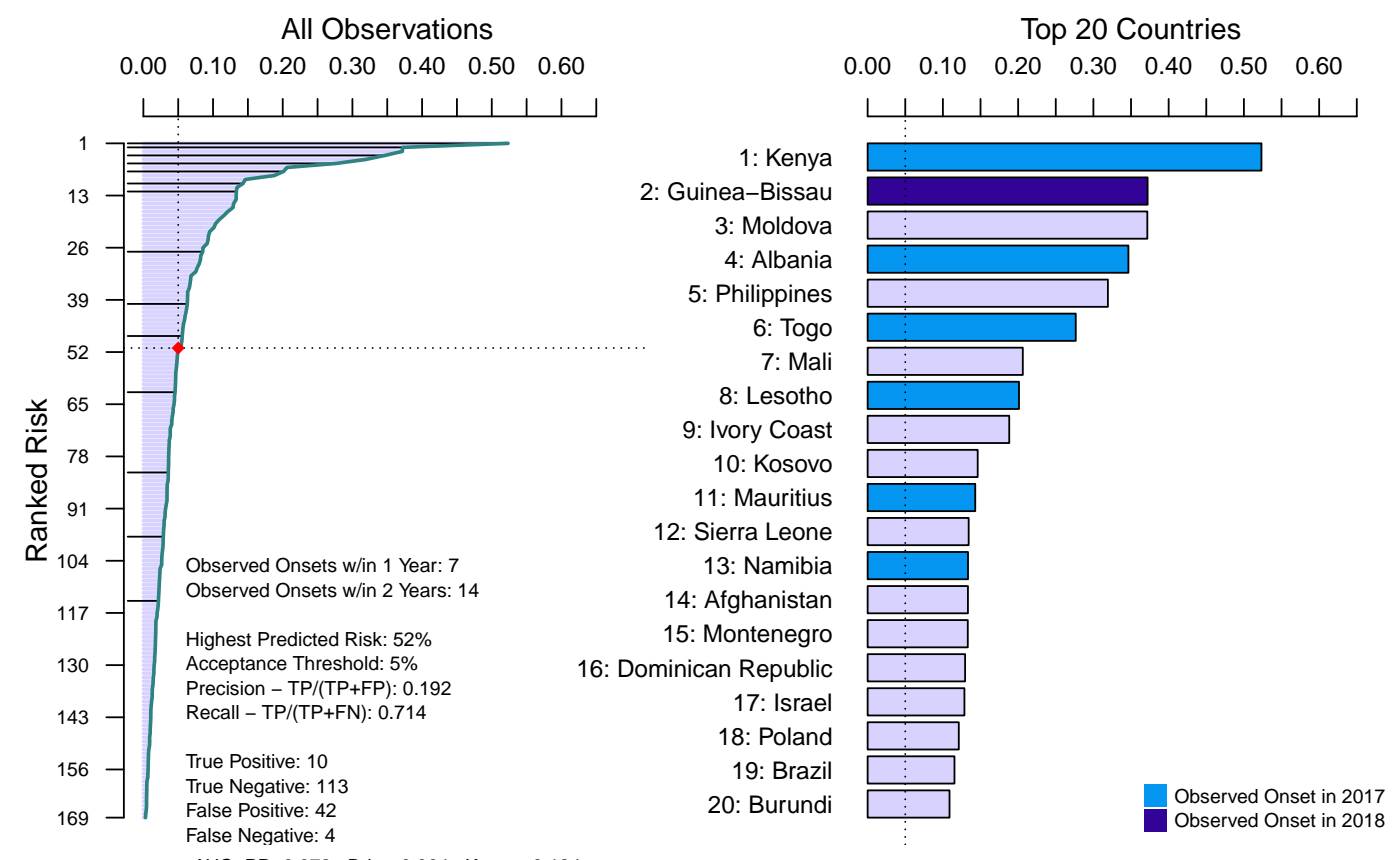

AUC-PR: 0.372; Brier: 0.064; Kappa: 0.124 
Figure 13: Ensemble: 2019-2020 Forecast

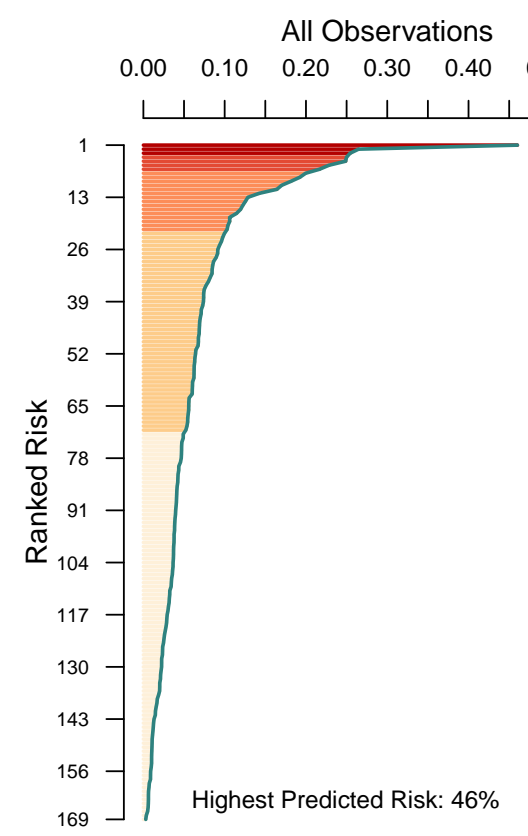

$0.50 \quad 0.60$

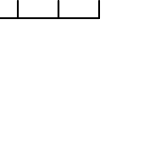

1: Philippines

2: Fiji

3: Mali

4: Hungary

5: Guatemala

6: Kosovo

7: Kyrgyzstan

8: Moldova

9: Bosnia and Herzegovina

10: Tanzania

11: Albania

12: Benin

13: The Gambia

14: Czech Republic

15: Italy

16: Nicaragua

17: Mauritius

18: Slovenia

19: Turkmenistan

20: Ghana

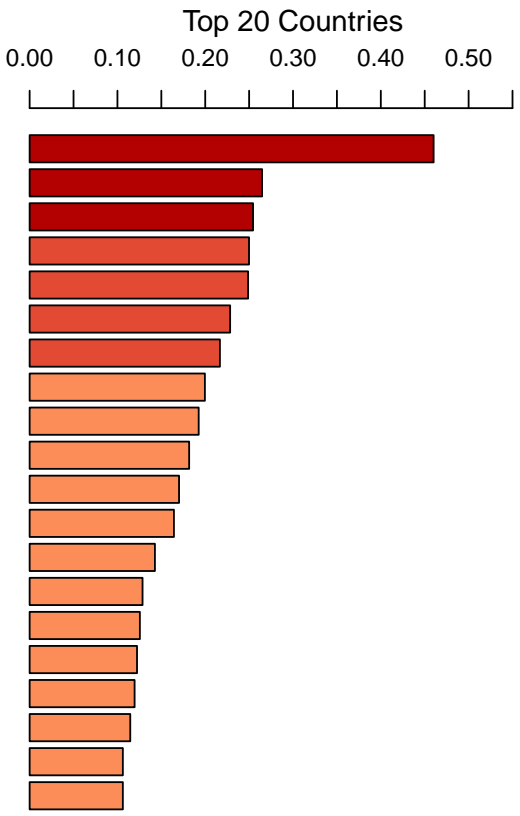

Figure 14: Logit w/elastic-net regularization: 2011-2012 Test Forecast
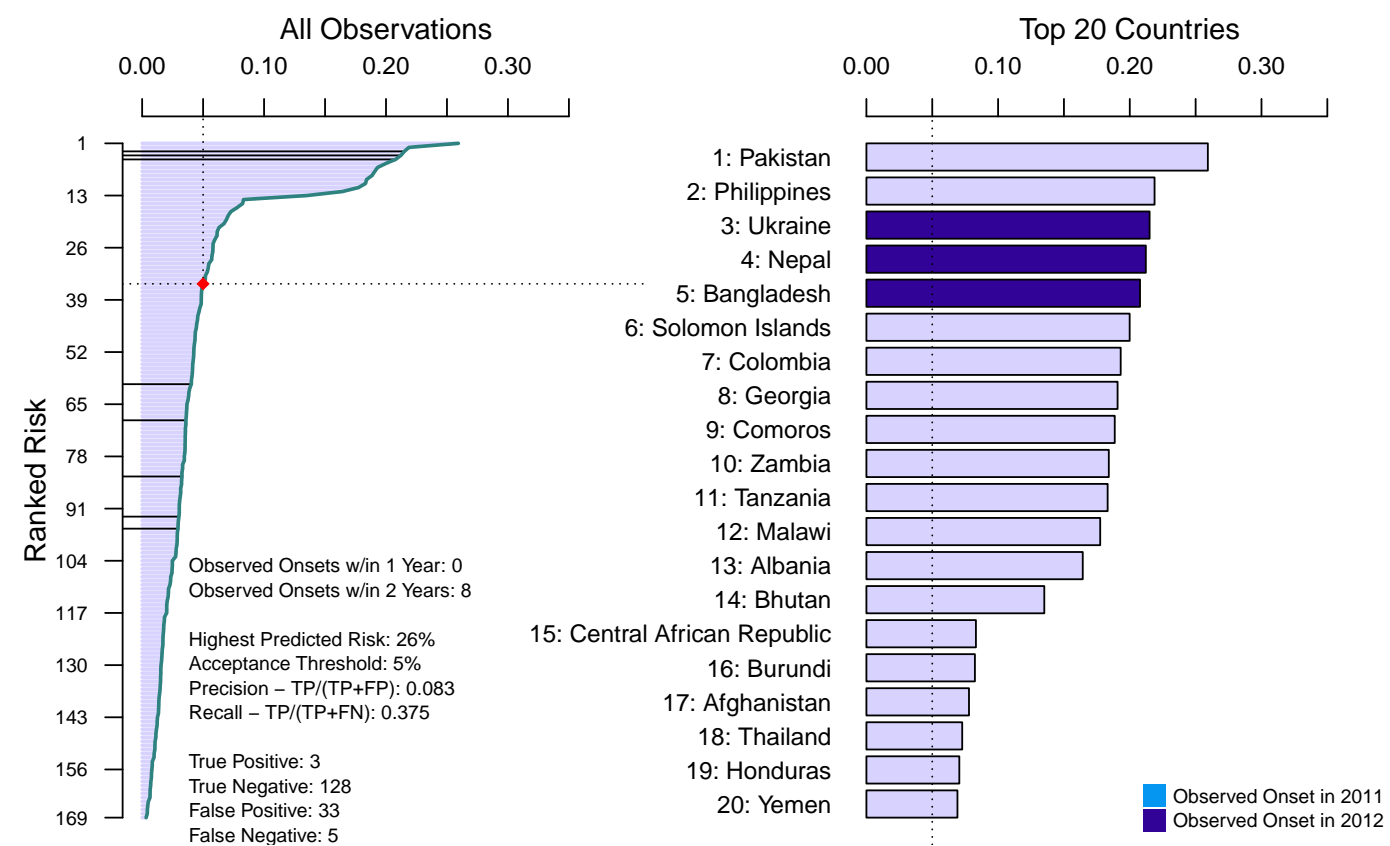

20: Yemen

AUC-PR: 0.184; Brier: 0.042; Kappa: 0 
Figure 15: Logit w/elastic-net regularization: 2012-2013 Test Forecast
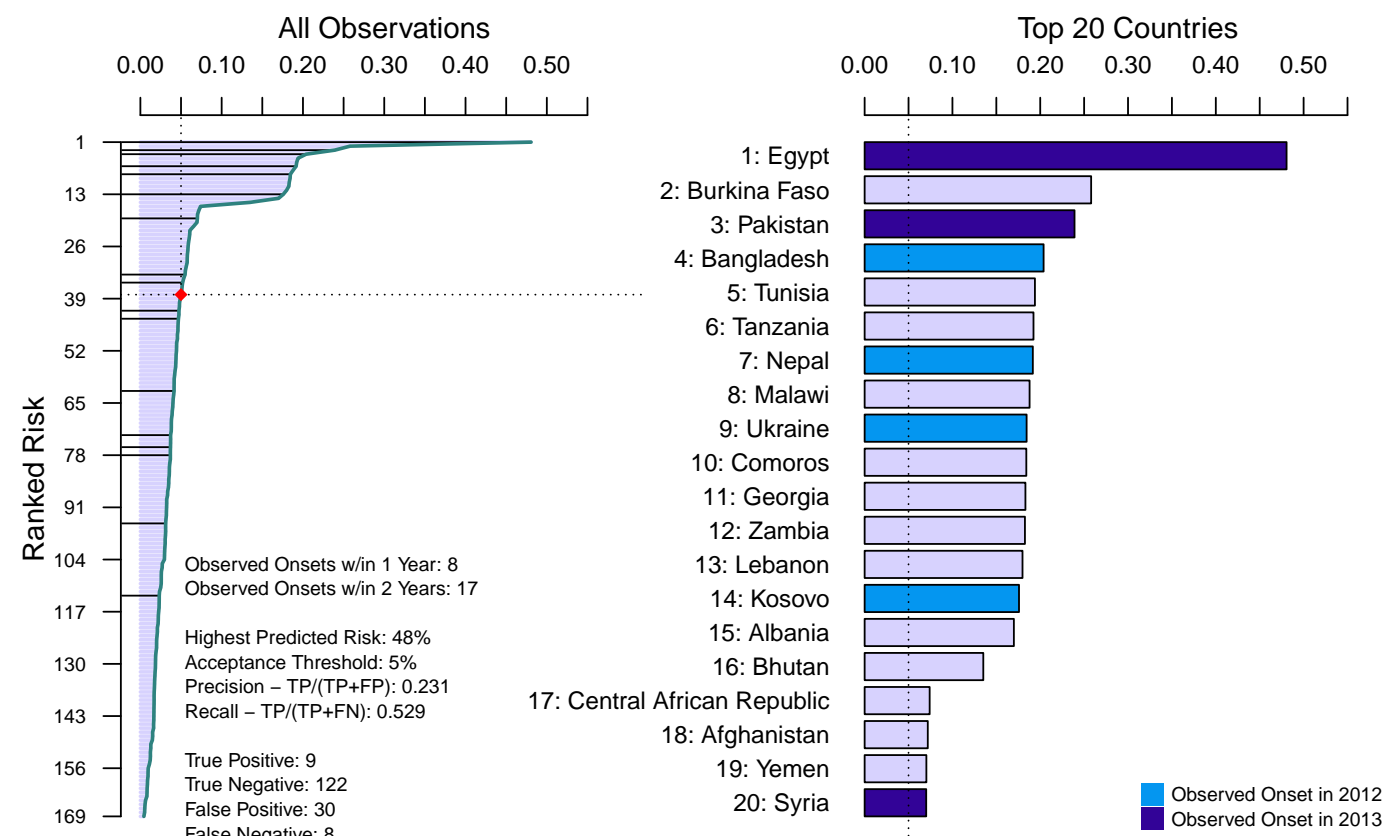

AUC-PR: 0.296; Brier: 0.083; Kappa: 0

Figure 16: Logit w/elastic-net regularization: 2013-2014 Test Forecast
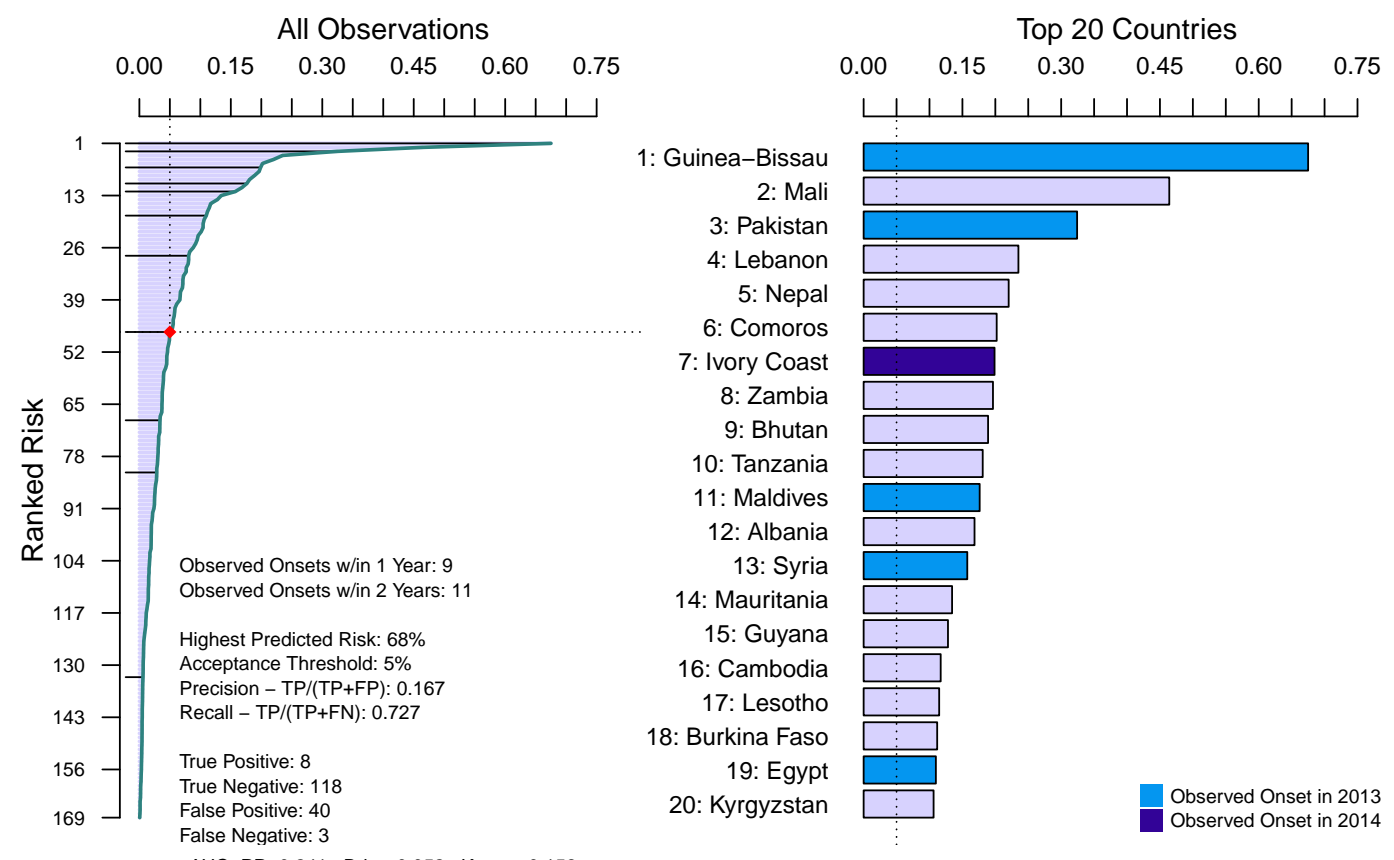

AUC-PR: 0.241; Brier: 0.052; Kappa: 0.158 
Figure 17: Logit w/elastic-net regularization: 2014-2015 Test Forecast

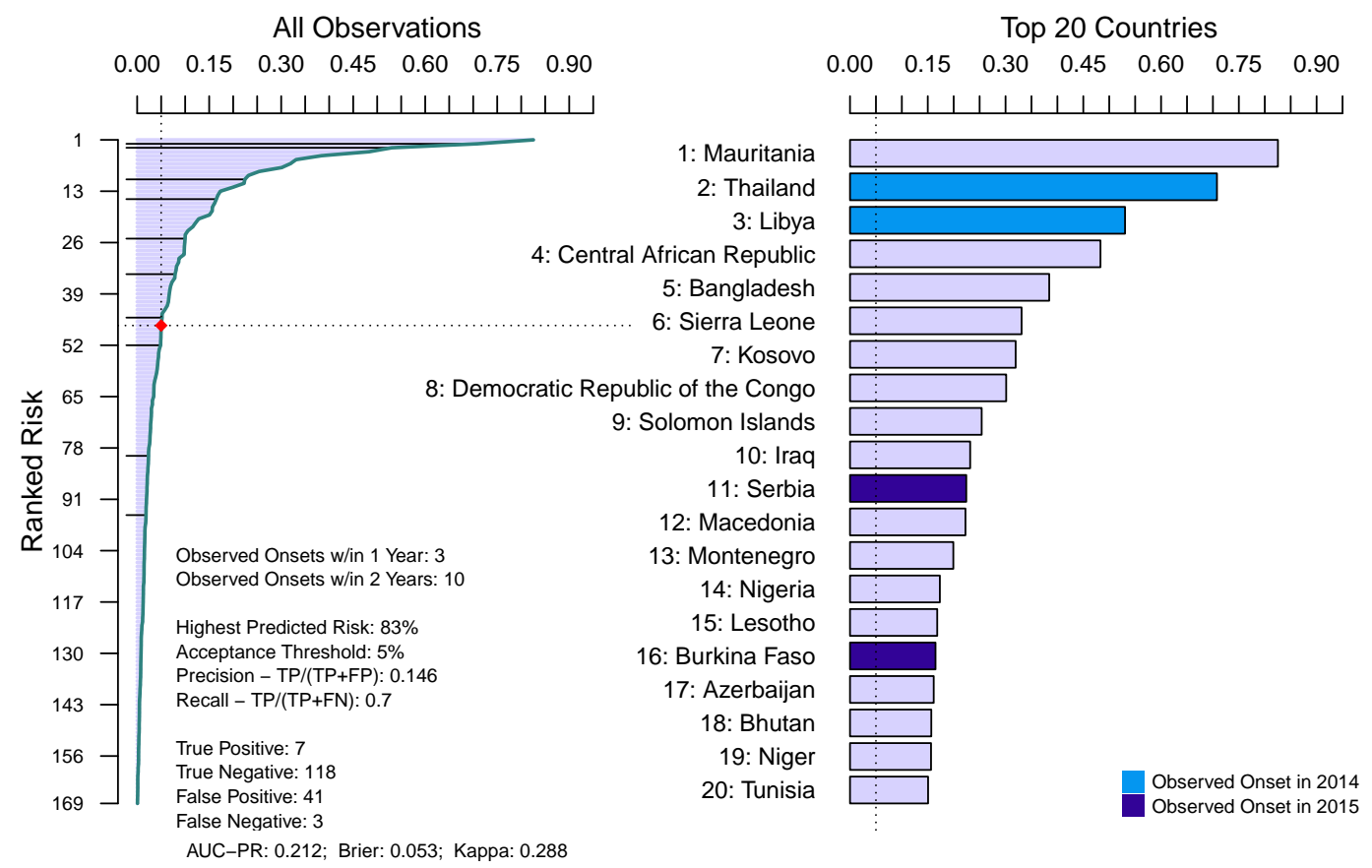

Figure 18: Logit w/elastic-net regularization: 2015-2016 Test Forecast
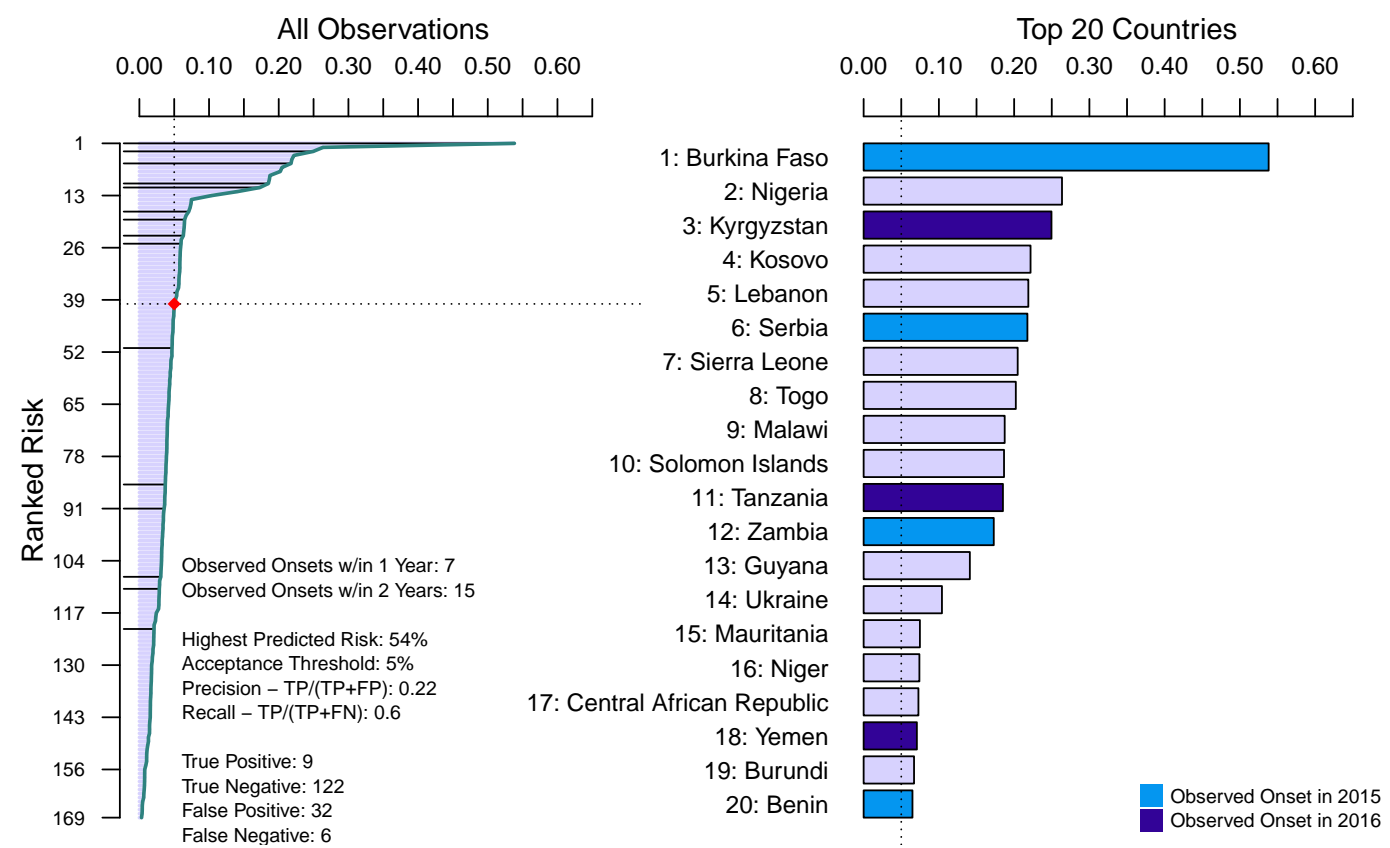

AUC-PR: 0.256; Brier: 0.073; Kappa: 0.115 
Figure 19: Logit w/elastic-net regularization: 2016-2017 Test Forecast

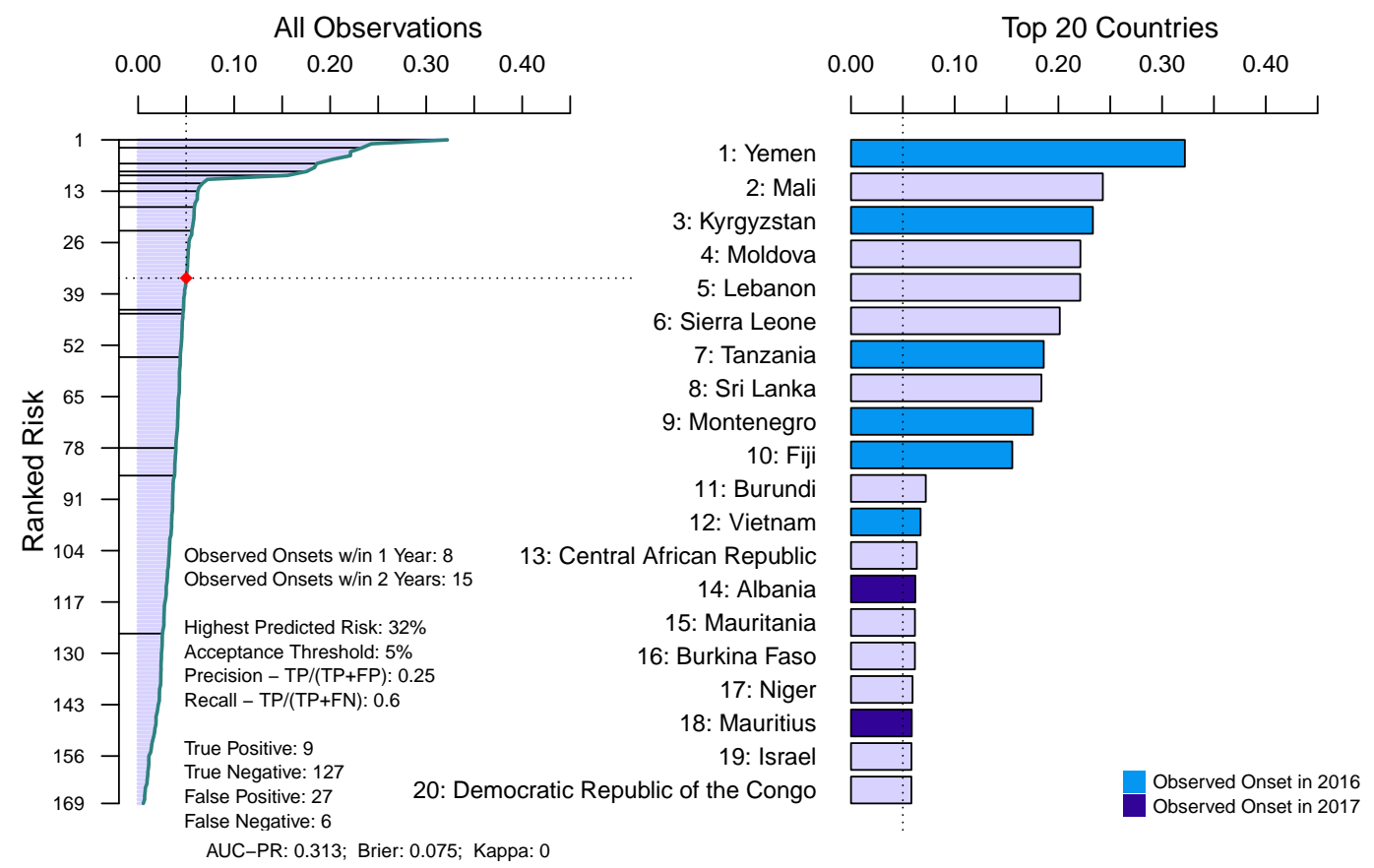

Figure 20: Logit w/elastic-net regularization: 2017-2018 Test Forecast
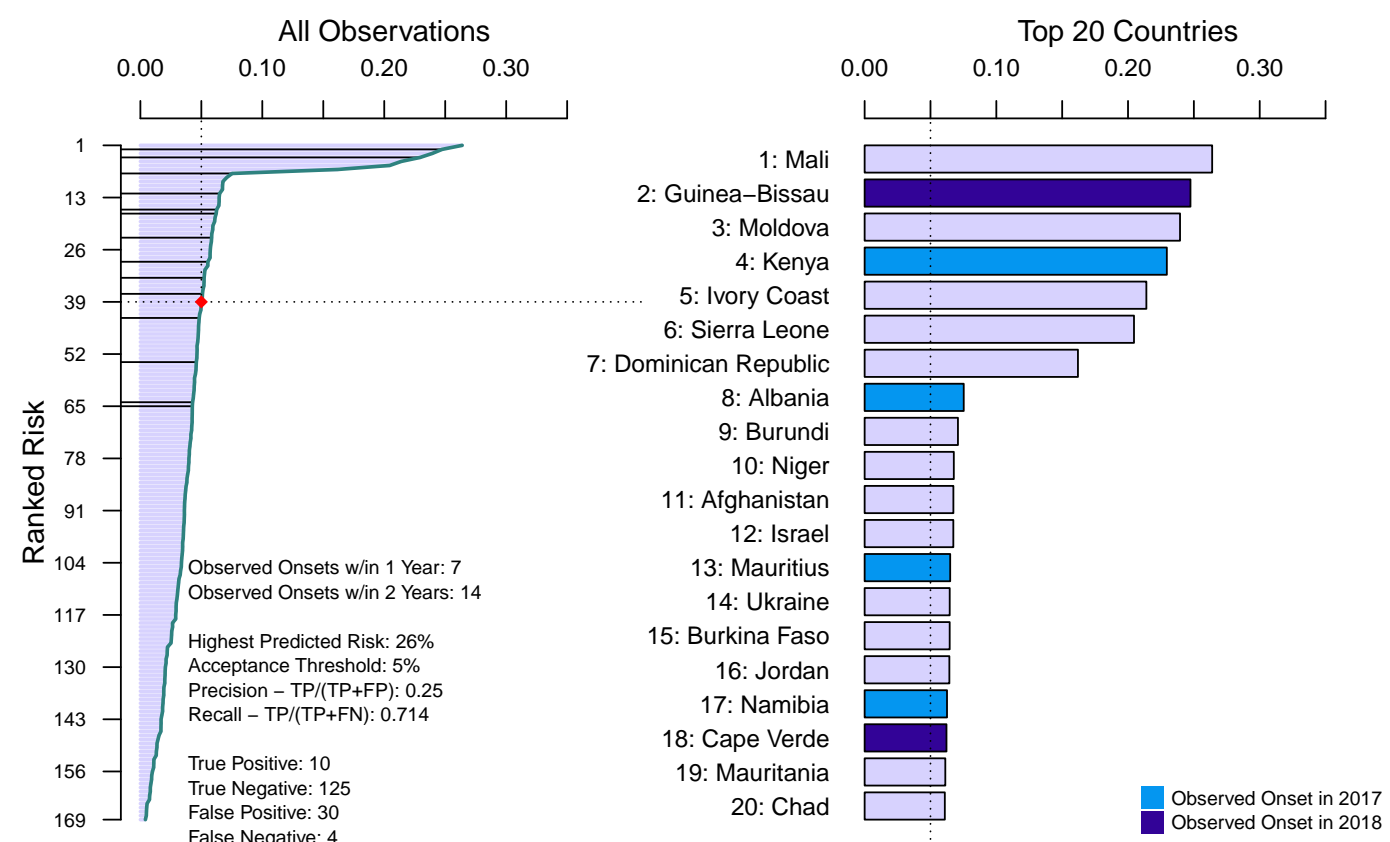

AUC-PR: 0.268; Brier: 0.073; Kappa: 0 
Figure 21: Logit w/elastic-net regularization: 2019-2020 Forecast
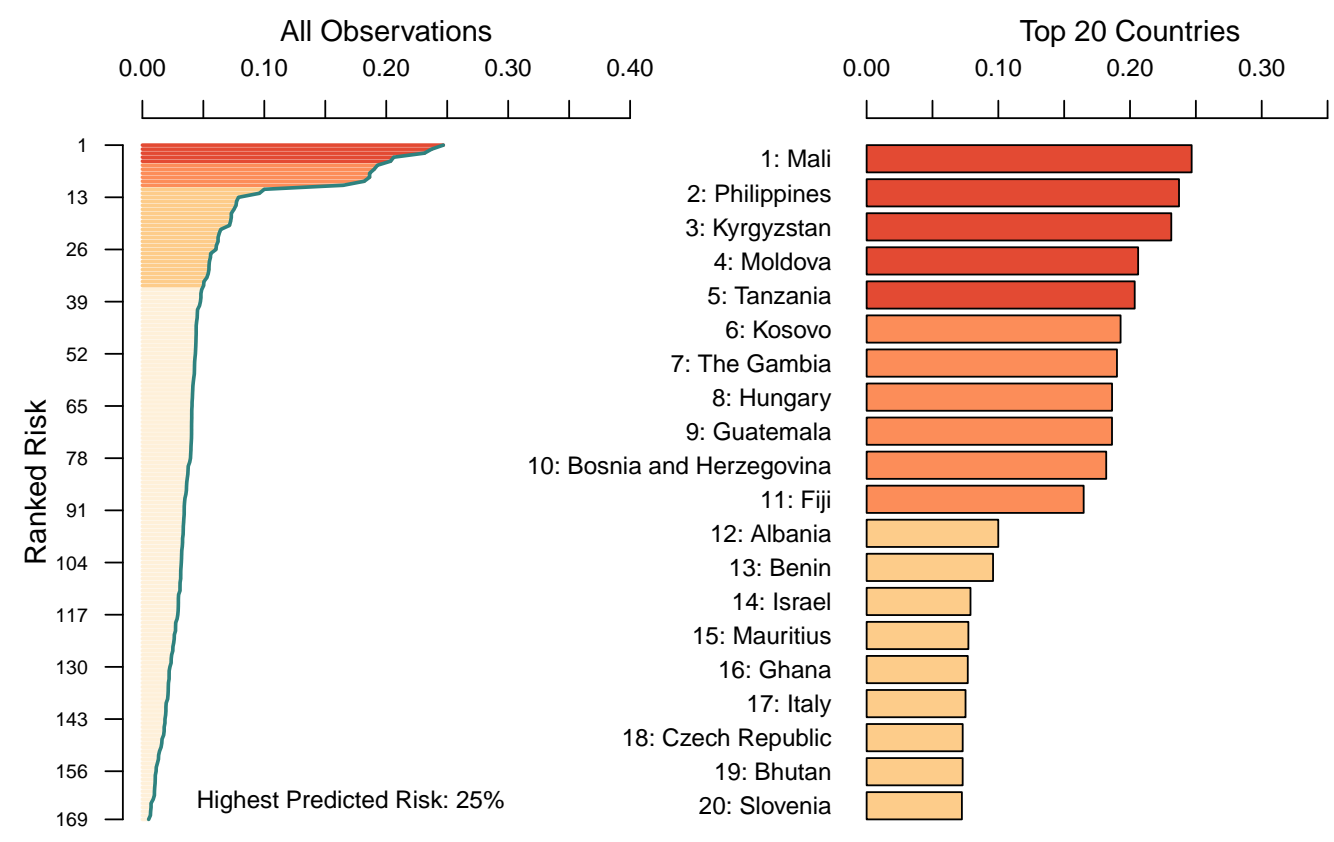

Figure 22: Random forest: 2011-2012 Test Forecast
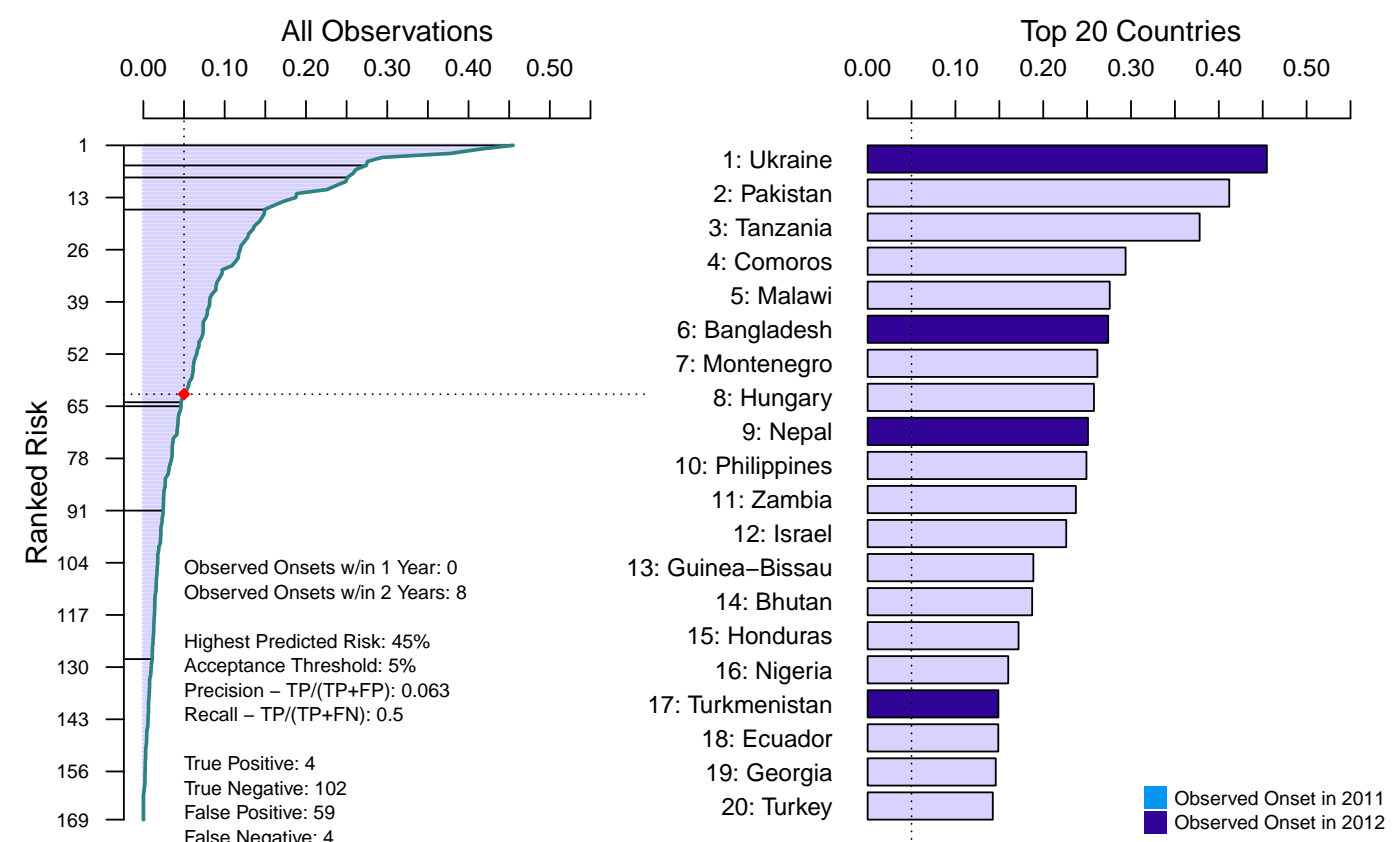

AUC-PR: 0.132; Brier: 0.043; Kappa: 0 
Figure 23: Random forest: 2012-2013 Test Forecast
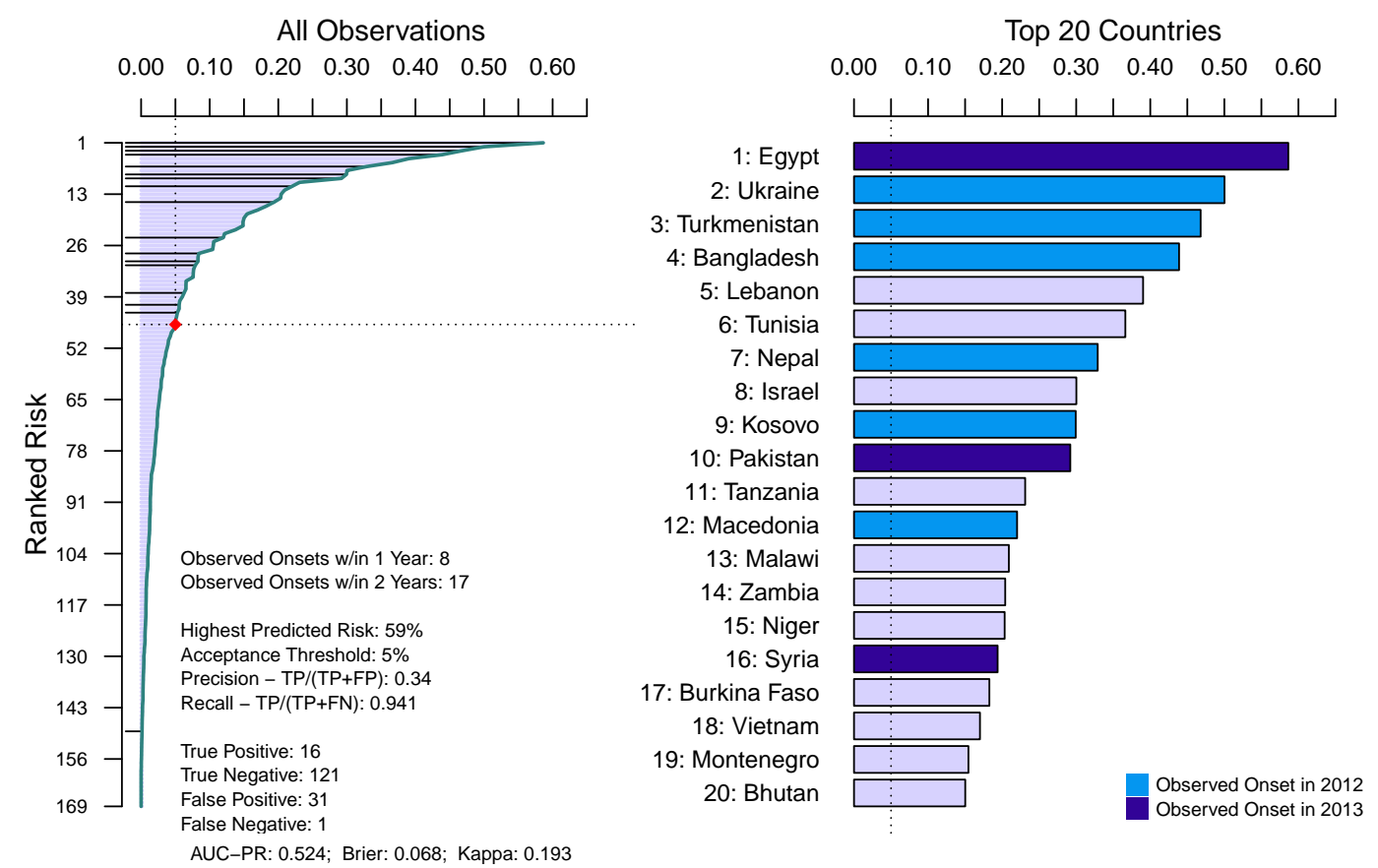

Figure 24: Random forest: 2013-2014 Test Forecast
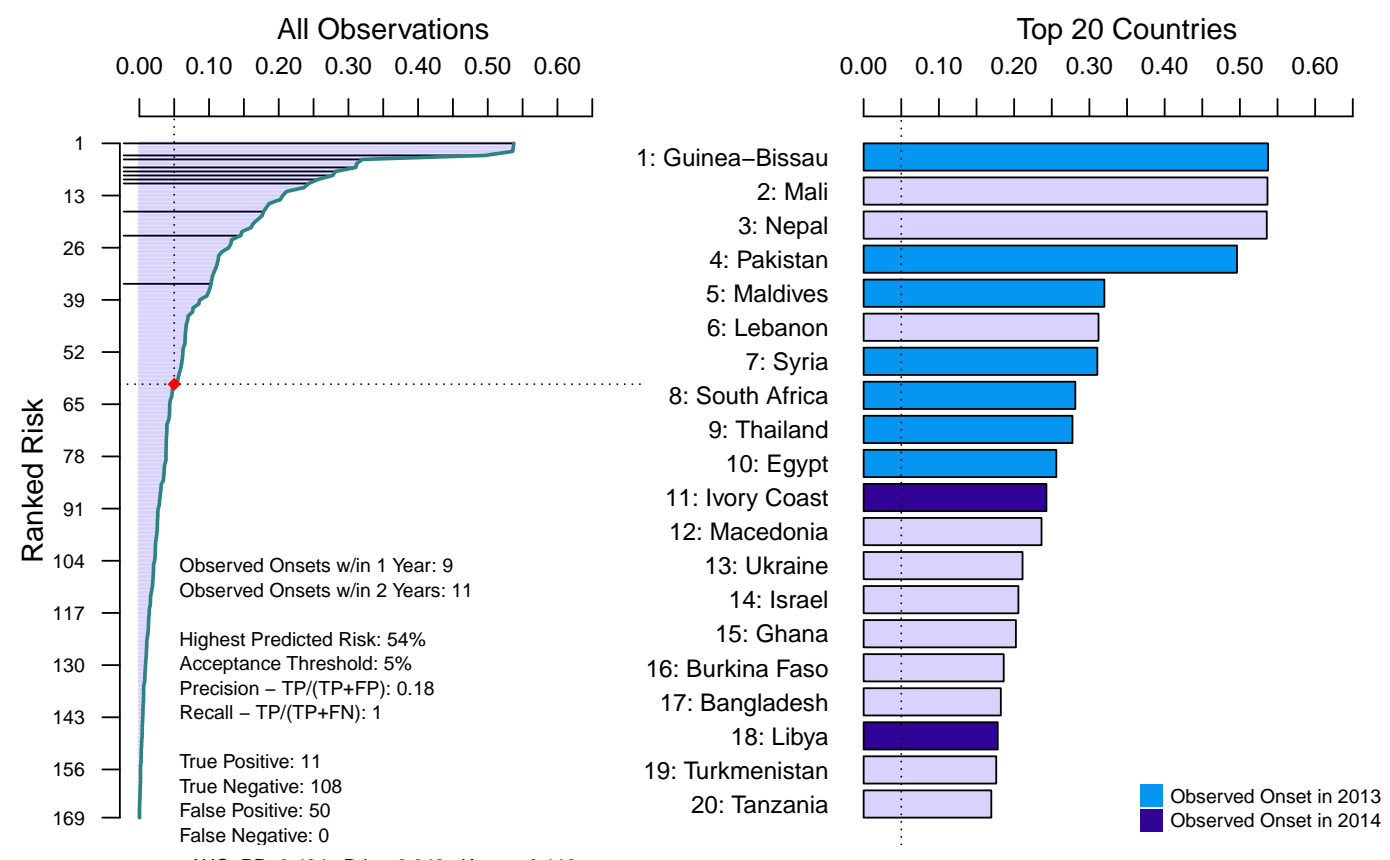
Figure 25: Random forest: 2014-2015 Test Forecast
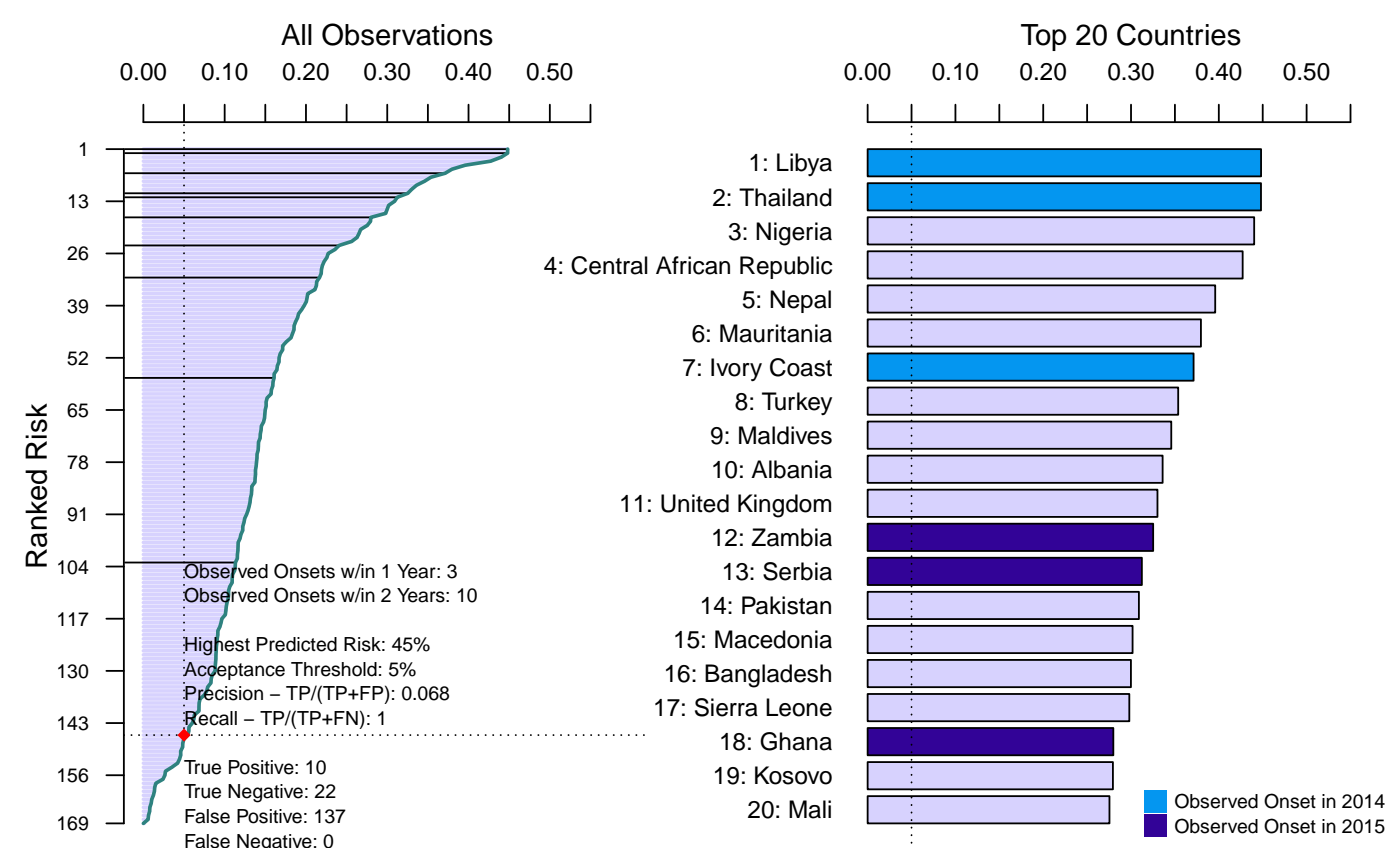

False Negative: 0

AUC-PR: 0.309; Brier: 0.056; Kappa: 0

Figure 26: Random forest: 2015-2016 Test Forecast

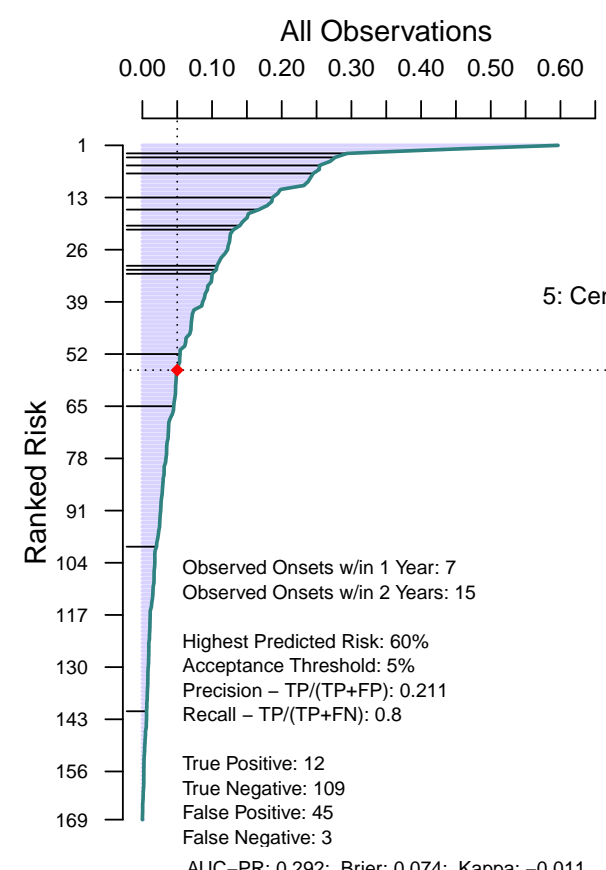

Top 20 Countries

\section{(c)}

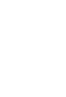

5: Centrat

: Ukraine

3: Serbia

4: Kyrgyzstan

Republic

6: Zambia

7: Kosovo

8: Burkina Faso

9: Nepal

10: Malawi

11: Nigeria

12: Lebanon

13: Iraq

14: Benin

15: Thailand

16: Turkey

17: Tanzania

18: Egypt

19: Sierra Leone

20: Guinea-Bissau

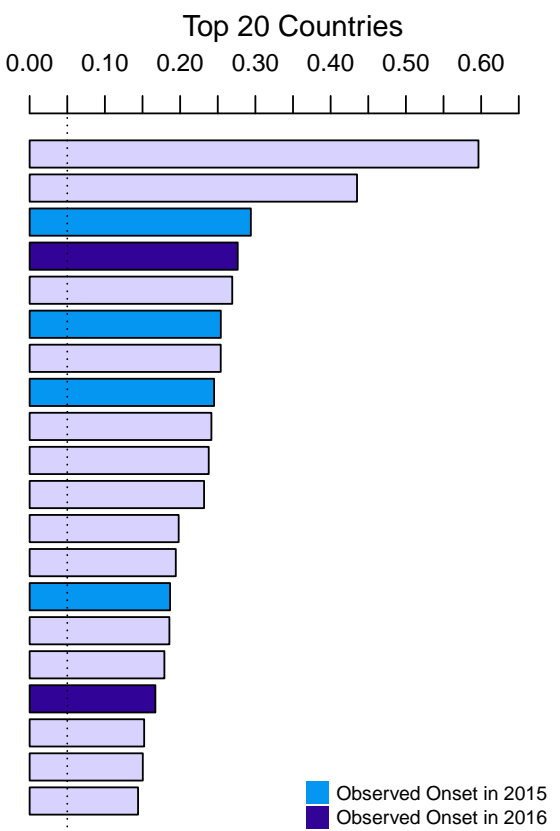

Observed Onset in 2015

AUC-PR: 0.292; Brier: 0.074; Kappa: -0.011 
Figure 27: Random forest: 2016-2017 Test Forecast
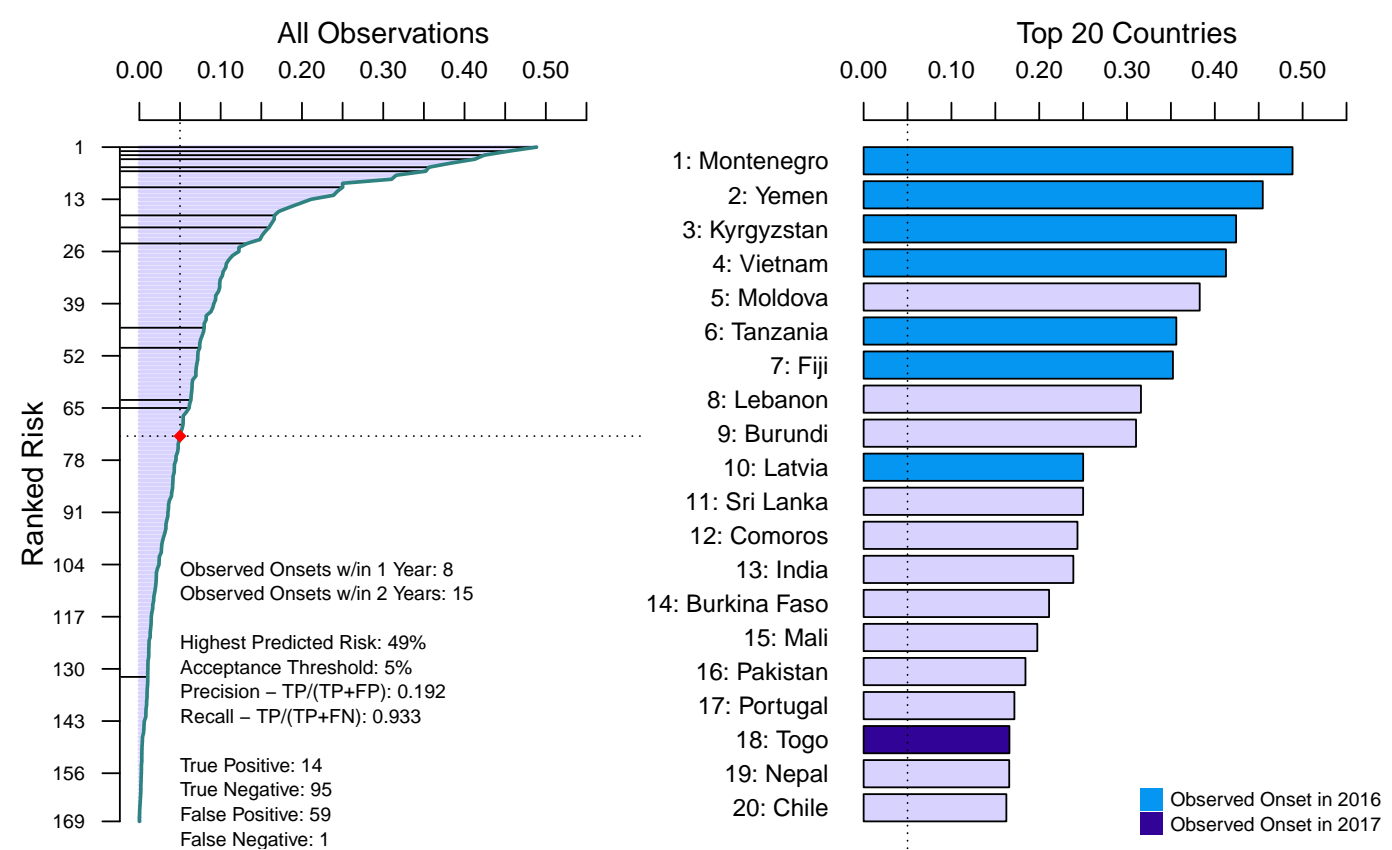

AUC-PR: 0.503; Brier: 0.061; Kappa: 0

Figure 28: Random forest: 2017-2018 Test Forecast
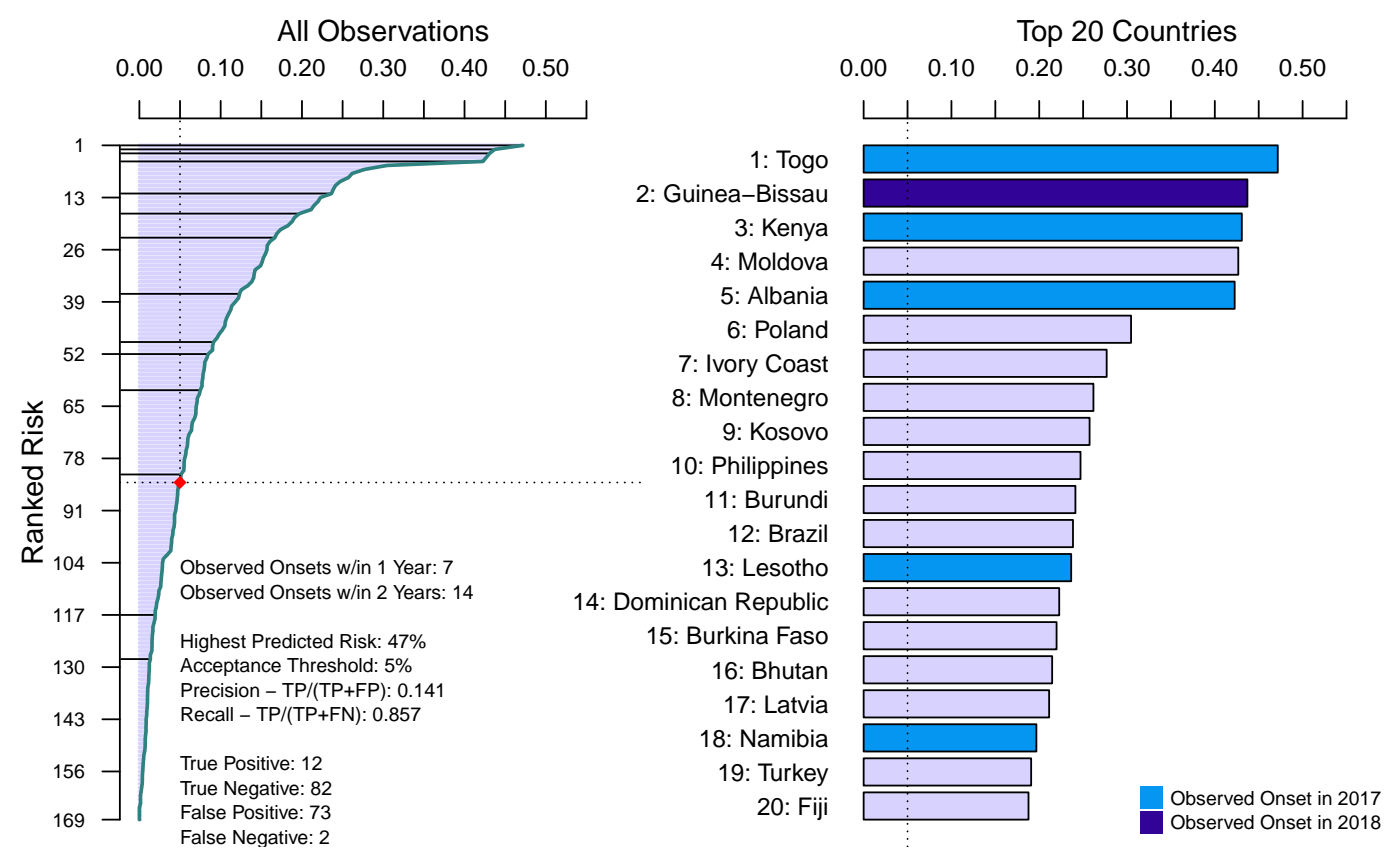

AUC-PR: 0.343; Brier: 0.065; Kappa: 0 
Figure 29: Random forest: 2019-2020 Forecast

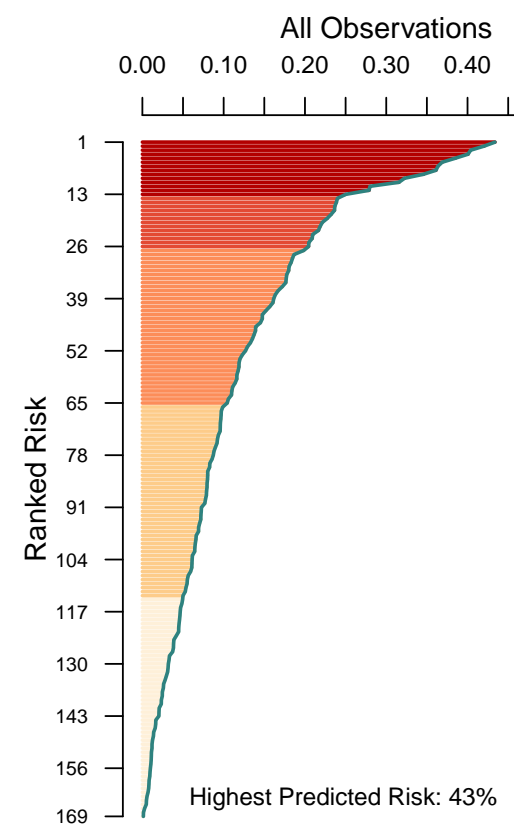

$0.50 \quad 0.60$

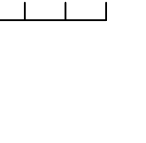

7: Bosnia and Herzegovina

8: Guatemala

9: Benin

10: Tanzania

11: Nicaragua

12: Mauritius

13: Italy

14: Colombia

15: Czech Republic

16: Kosovo

17: Armenia

18: Turkmenistan

19: Somalia

20: Ghana

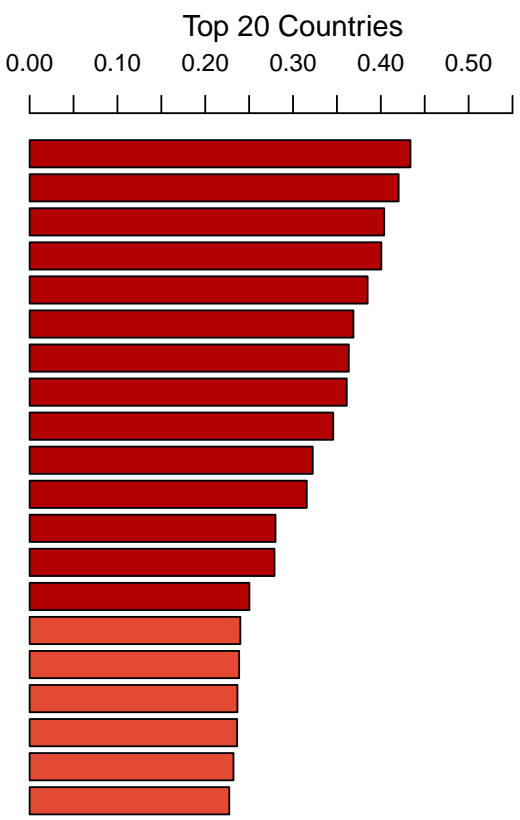

Figure 30: Gradient boosted forest: 2011-2012 Test Forecast
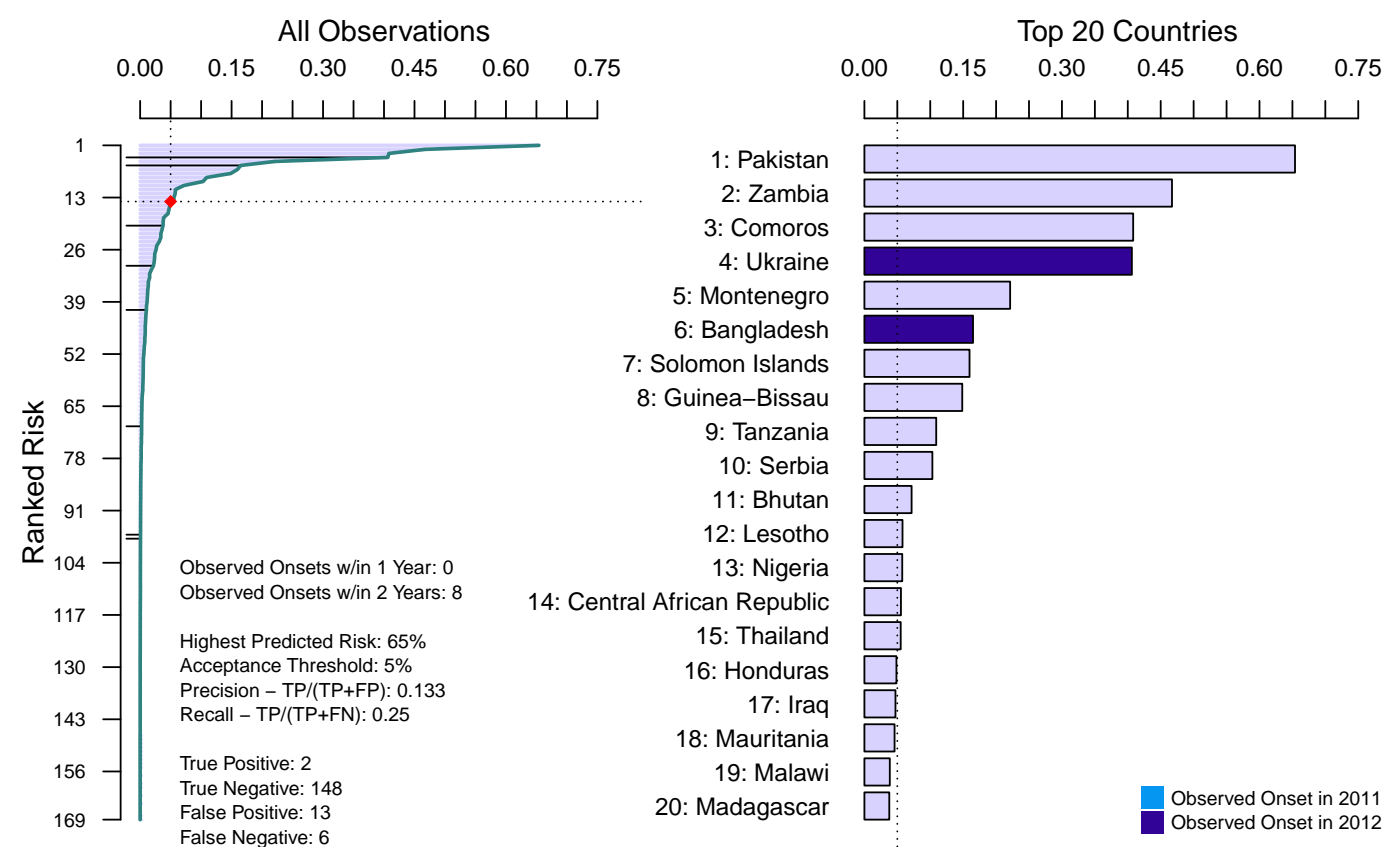

AUC-PR: 0.12; Brier: 0.047; Kappa: -0.011 
Figure 31: Gradient boosted forest: 2012-2013 Test Forecast
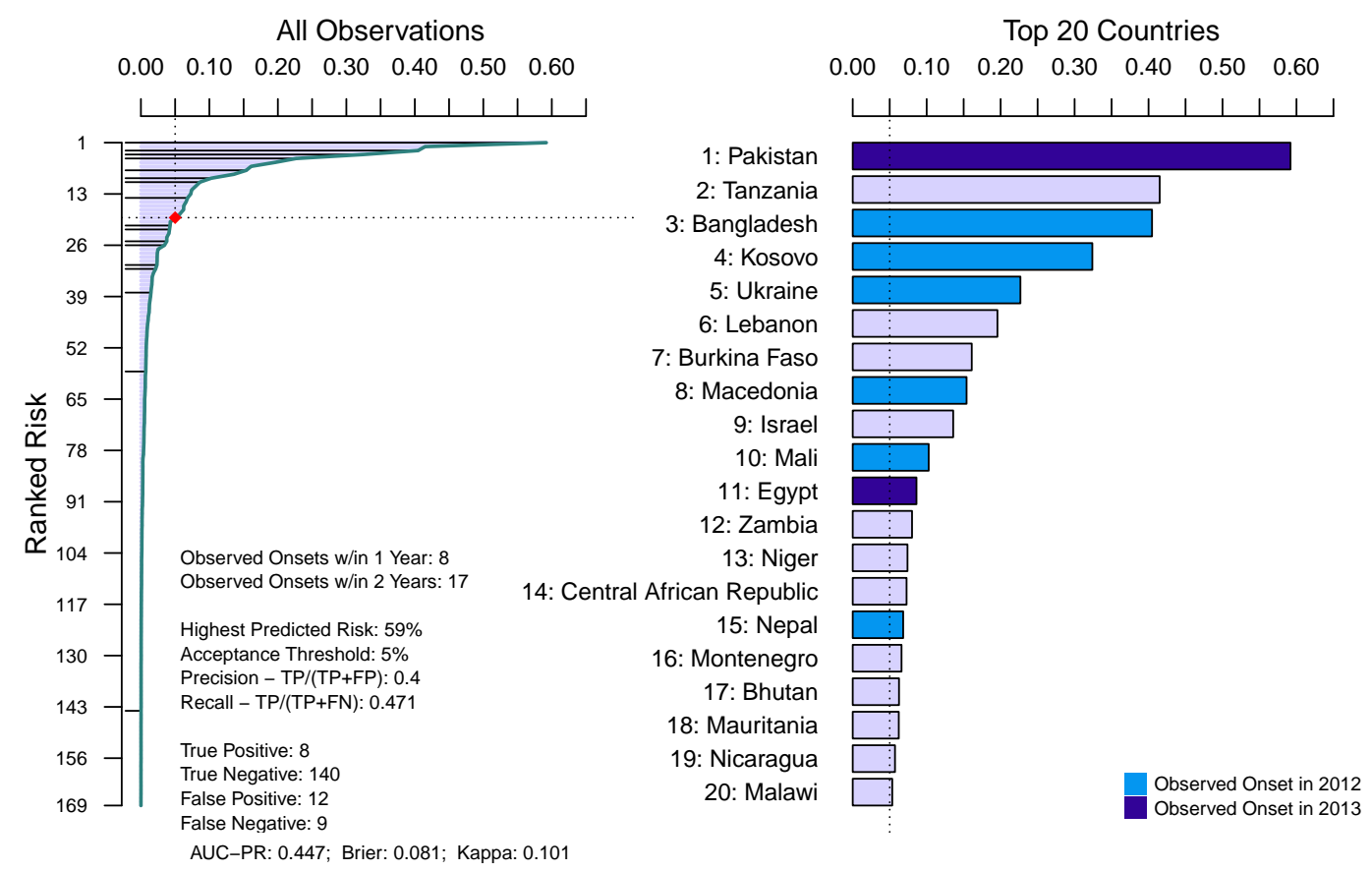

Figure 32: Gradient boosted forest: 2013-2014 Test Forecast
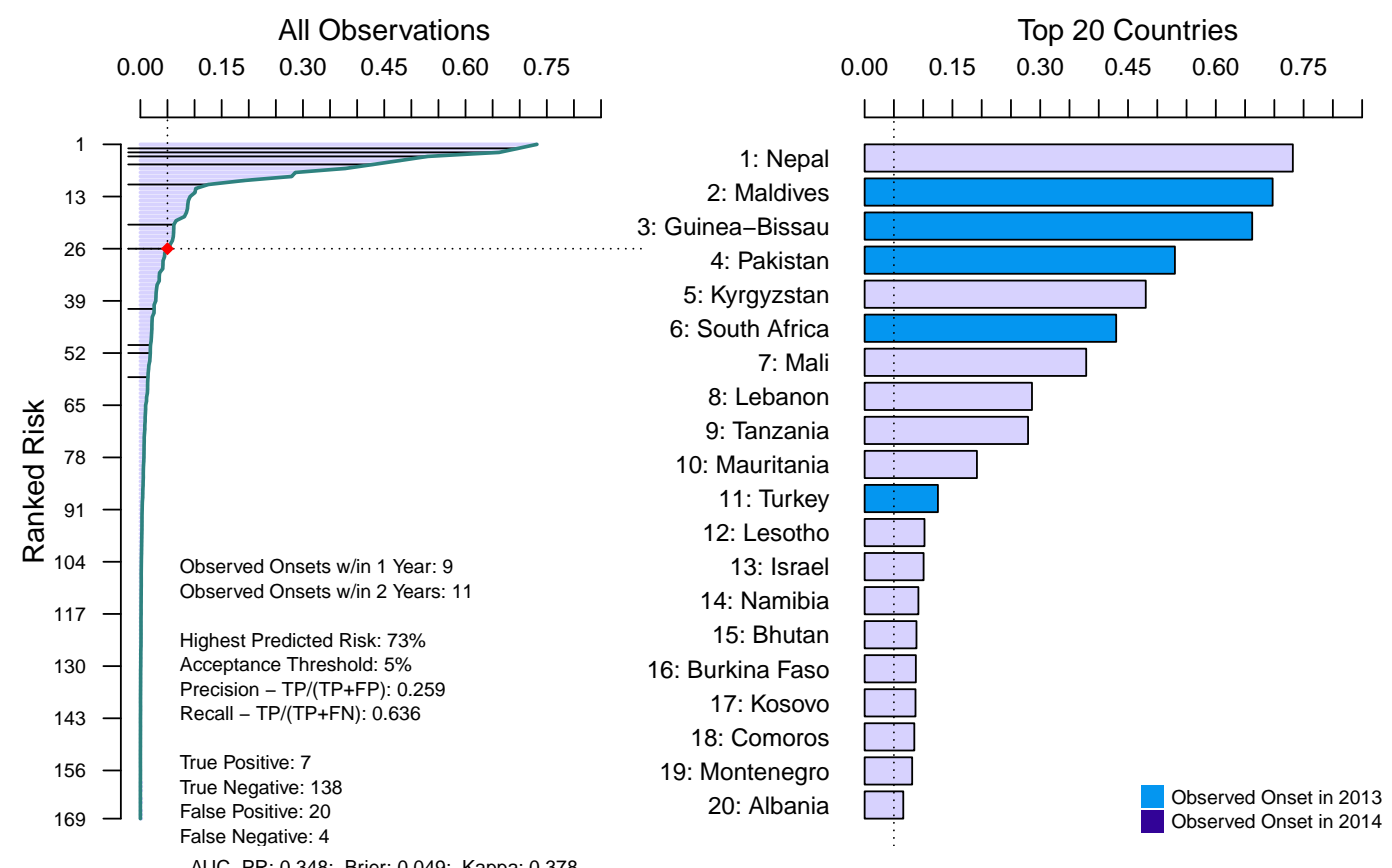
Figure 33: Gradient boosted forest: 2014-2015 Test Forecast

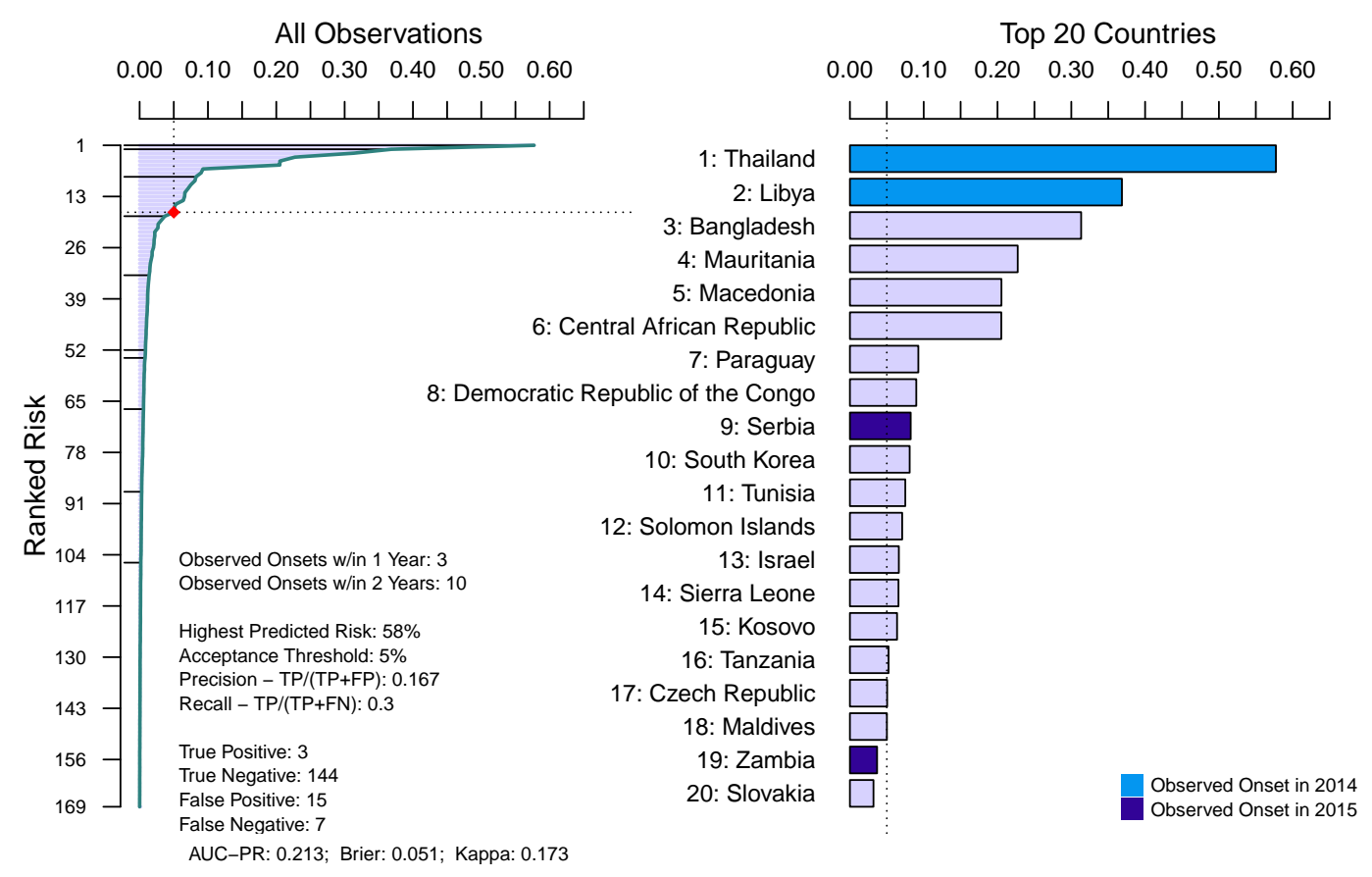

Figure 34: Gradient boosted forest: 2015-2016 Test Forecast
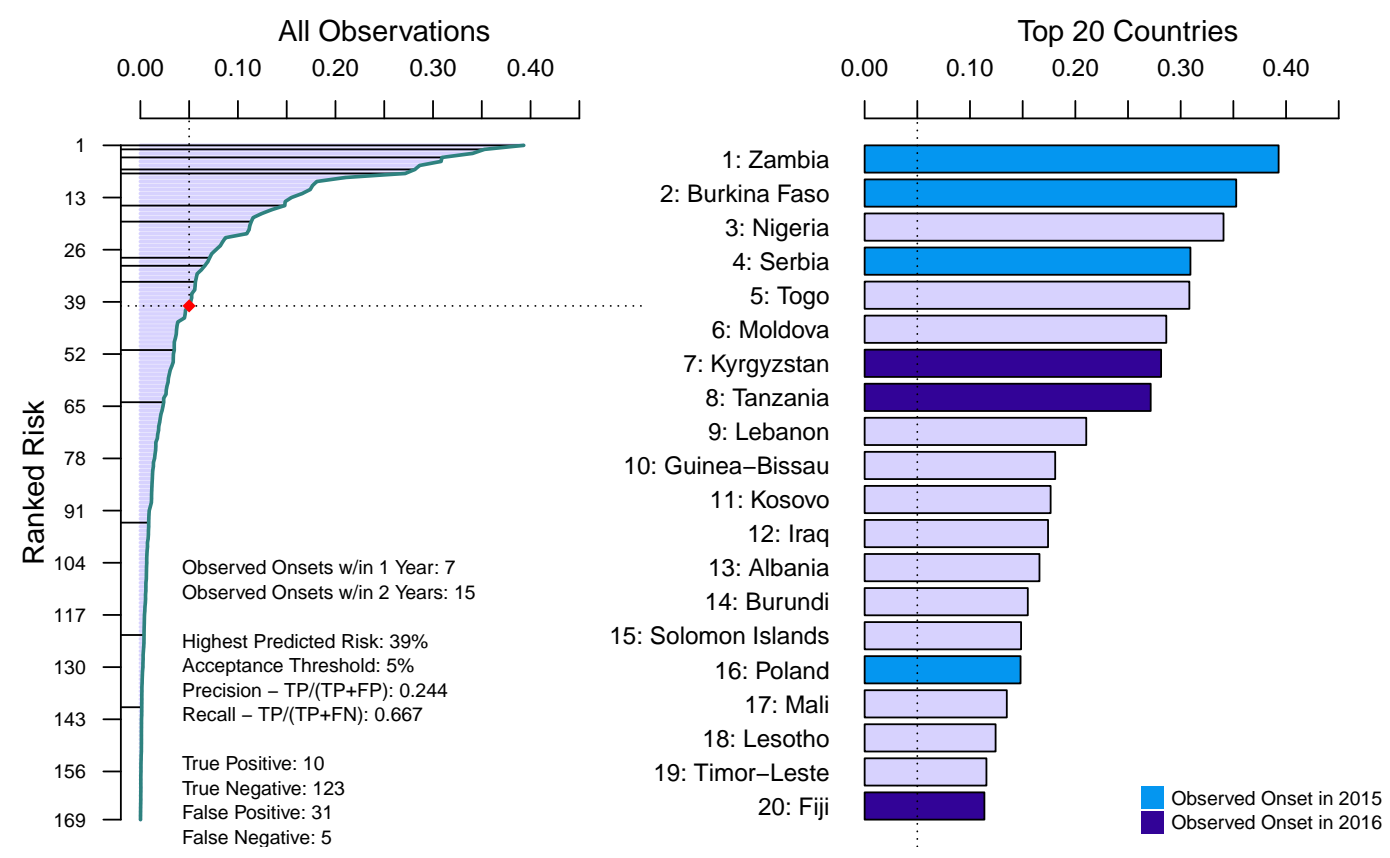

AUC-PR: 0.338; Brier: 0.071; Kappa: 0 
Figure 35: Gradient boosted forest: 2016-2017 Test Forecast
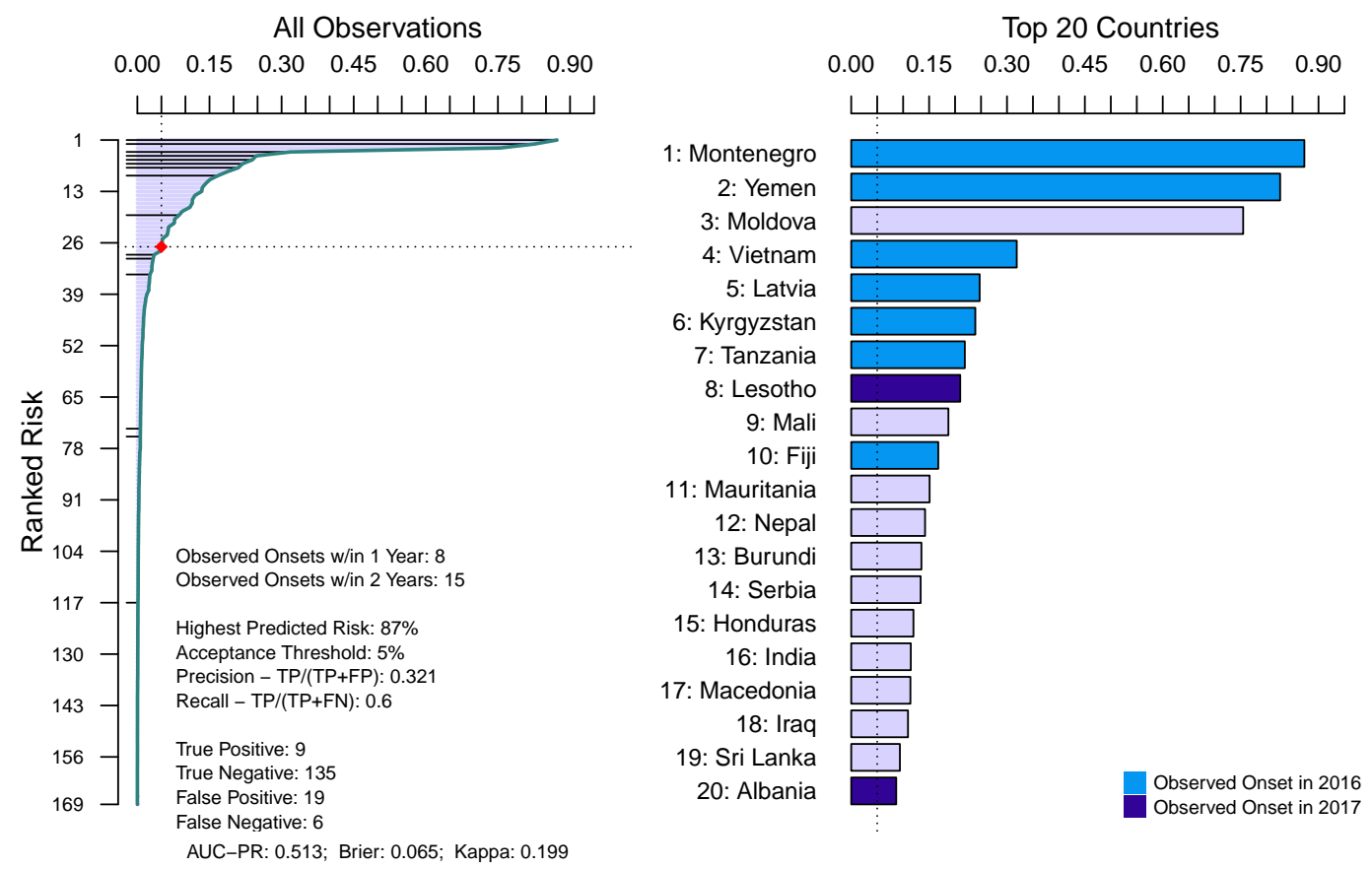

Figure 36: Gradient boosted forest: 2017-2018 Test Forecast
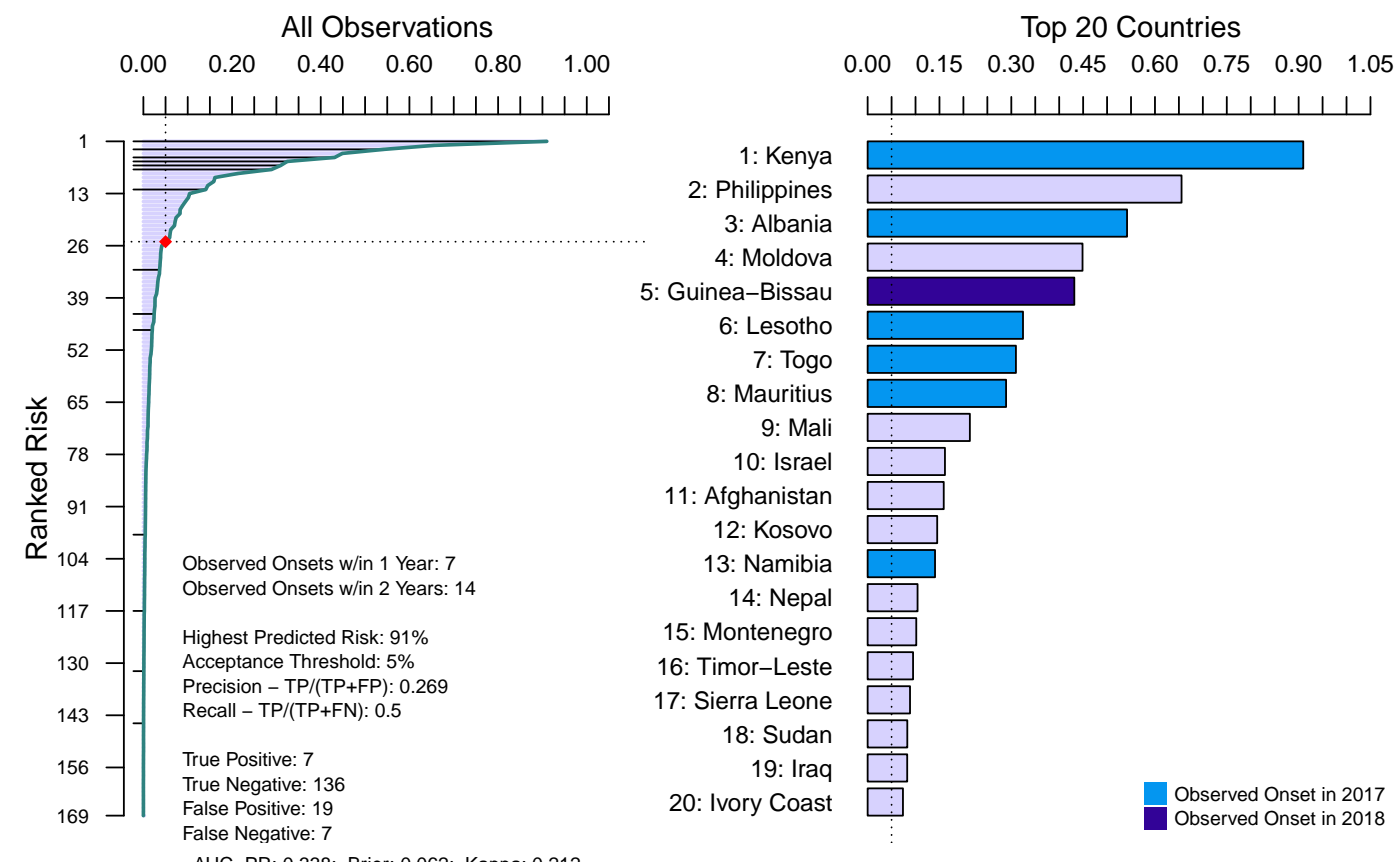
Figure 37: Gradient boosted forest: 2019-2020 Forecast

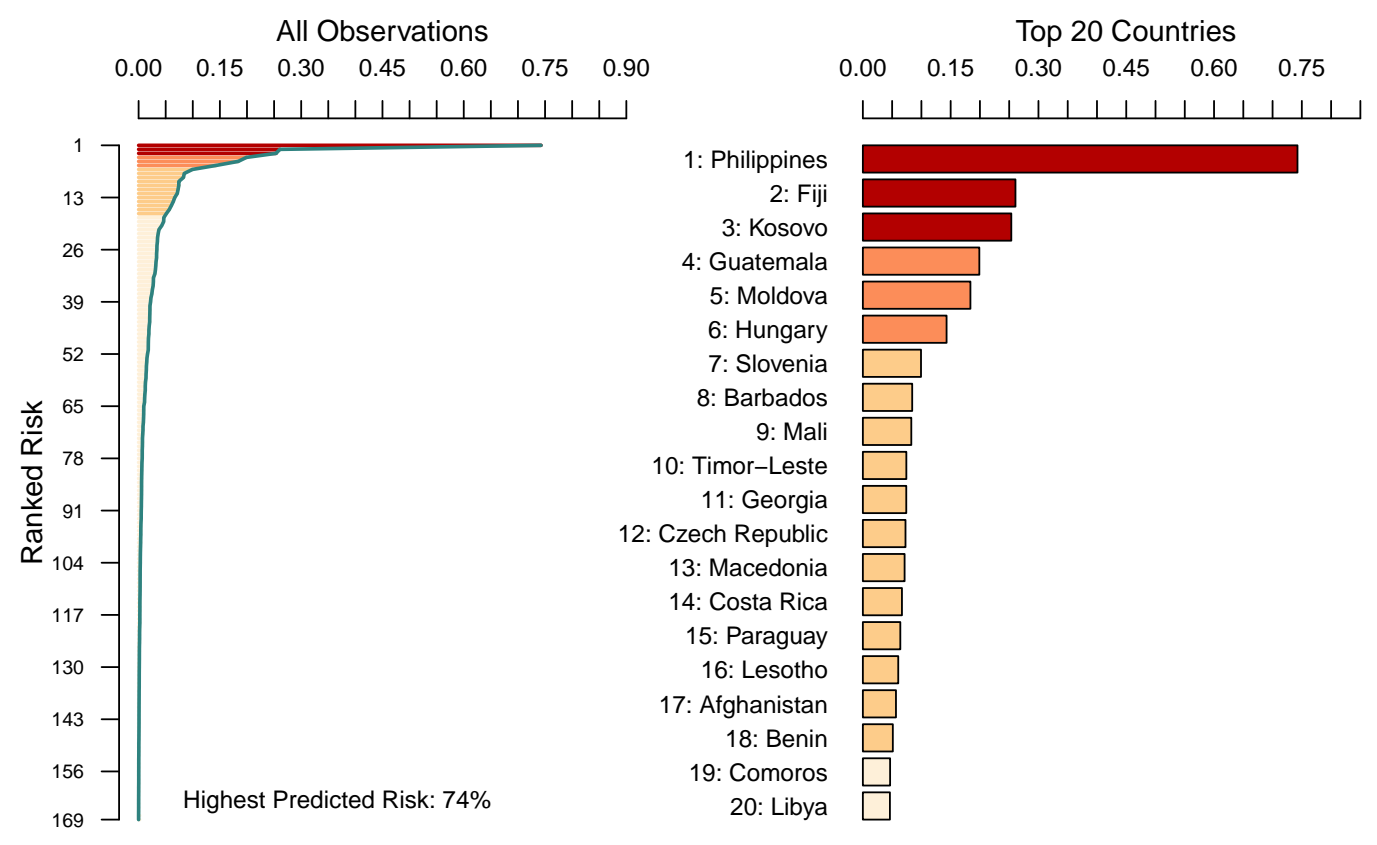




\section{Appendix: Adverse Regime Transitions}

The tables below lists the 189 adverse regime transitions that are captured in our data by year. They provide the RoW classification before and after the ART event as well as the year that the event manifested.

Table 8: Adverse Regime Transitions - 1970-2018

\begin{tabular}{|c|c|c|c|c|}
\hline & $\begin{array}{l}\text { Country } \\
\text { Name }\end{array}$ & $\begin{array}{l}\text { RoW Classification } \\
\text { before ART }\end{array}$ & $\begin{array}{l}\text { RoW Classification } \\
\text { after ART }\end{array}$ & $\begin{array}{r}\text { Year of } \\
\text { ART }\end{array}$ \\
\hline 1 & Bolivia & Electoral Autocracy & Closed Autocracy & 1970 \\
\hline 2 & & & & 1970 \\
\hline 3 & Somalia & Electoral Autocracy & Closed Autocracy & 1970 \\
\hline 4 & Cambodia & Electoral Autocracy & Closed Autocracy & 1971 \\
\hline 5 & Lesotho & Electoral Autocracy & Closed Autocracy & 1971 \\
\hline 6 & Ecuador & Electoral Autocracy & Closed Autocracy & 1972 \\
\hline 7 & Madagascar & Electoral Autocr & & 1972 \\
\hline 8 & Philippines & Electoral Autocr & Close & 1972 \\
\hline 9 & Uruguay & Electoral Democracy & Electoral Autocracy & 1972 \\
\hline 10 & Cambodia & Electoral Autocracy & Closed Autocracy & 1973 \\
\hline 11 & Chile & cy & Ele & 1973 \\
\hline 12 & Ghana & Elect & Clos & 1973 \\
\hline 13 & Honduras & Electoral Autocracy & Closed Autocr & 1973 \\
\hline 14 & Uruguay & Electoral Autocracy & Closed Autocracy & 1973 \\
\hline 15 & & & & 1974 \\
\hline 16 & Chile & Electoral Autocracy & Closed Autocracy & 1974 \\
\hline 17 & Jamaica & Electoral Democracy & Electoral Autocracy & 1974 \\
\hline 18 & Nicaragua & Electoral Autocracy & Closed Autocracy & 1974 \\
\hline 19 & Rwanda & & Clos & 1974 \\
\hline 20 & Tunisia & Electoral Autocracy & Closed Autocracy & 1974 \\
\hline 21 & Banglade & & & 1975 \\
\hline 22 & India & & Elec & 1975 \\
\hline 23 & Laos & Electoral Autocracy & Closed Autocracy & 1975 \\
\hline 24 & Argentin & Electoral Democra & Elect & 1976 \\
\hline 25 & Cape Verde & & Closed Autocracy & 1976 \\
\hline 26 & Israel & Liberal Democracy & Electoral Democracy & 1976 \\
\hline
\end{tabular}


Table 8: Adverse Regime Transitions - 1970-2018 (cont.)

\begin{tabular}{|c|c|c|c|c|}
\hline & $\begin{array}{l}\text { Country } \\
\text { Name }\end{array}$ & $\begin{array}{l}\text { RoW Classification } \\
\text { before ART }\end{array}$ & $\begin{array}{l}\text { RoW Classification } \\
\text { after ART }\end{array}$ & $\begin{array}{r}\text { Year } \\
\text { of ART }\end{array}$ \\
\hline 27 & Argentina & Electoral Autocracy & Closed Autocracy & 1977 \\
\hline 28 & Colombia & Electoral Democracy & Electoral Autocracy & 1977 \\
\hline 29 & Sudan & Electoral Autocracy & Closed Autocracy & 1977 \\
\hline 30 & Thailand & Electoral Autocracy & Closed Autocracy & 1977 \\
\hline 31 & Vietnam & Electoral Autocracy & Closed Autocracy & 1977 \\
\hline 32 & Comoros & Electoral Autocracy & Closed Autocracy & 1978 \\
\hline 33 & Malawi & Electoral Autocracy & Closed Autocracy & 1978 \\
\hline 34 & Pakistan & Electoral Autocracy & Closed Autocracy & 1978 \\
\hline 35 & The Gambia & Electoral Democracy & Electoral Autocracy & 1978 \\
\hline 36 & Zimbabwe & Electoral Autocracy & Closed Autocracy & 1978 \\
\hline 37 & Equatorial Guinea & Electoral Autocracy & Closed Autocracy & 1979 \\
\hline 38 & El Salvador & Electoral Autocracy & Closed Autocracy & 1980 \\
\hline 39 & Suriname & Electoral Democracy & Closed Autocracy & 1980 \\
\hline 40 & Turkey & Electoral Democracy & Closed Autocracy & 1980 \\
\hline 41 & Bolivia & Electoral Autocracy & Closed Autocracy & 1981 \\
\hline 42 & Burkina Faso & Electoral Autocracy & Closed Autocracy & 1981 \\
\hline 43 & Ghana & Electoral Democracy & Closed Autocracy & 1981 \\
\hline 44 & Jamaica & Electoral Democracy & Electoral Autocracy & 1981 \\
\hline 45 & Philippines & Electoral Autocracy & Closed Autocracy & 1981 \\
\hline 46 & Solomon Islands & Electoral Democracy & Electoral Autocracy & 1981 \\
\hline 47 & Djibouti & Electoral Autocracy & Closed Autocracy & 1982 \\
\hline 48 & Senegal & Electoral Democracy & Electoral Autocracy & 1982 \\
\hline 49 & Bangladesh & Electoral Autocracy & Closed Autocracy & 1983 \\
\hline 50 & Guatemala & Electoral Autocracy & Closed Autocracy & 1983 \\
\hline 51 & Colombia & Electoral Democracy & Electoral Autocracy & 1984 \\
\hline 52 & Nigeria & Electoral Autocracy & Closed Autocracy & 1984 \\
\hline 53 & Somalia & Electoral Autocracy & Closed Autocracy & 1984 \\
\hline 54 & South Africa & Electoral Autocracy & Closed Autocracy & 1985 \\
\hline 55 & Sudan & Electoral Autocracy & Closed Autocracy & 1985 \\
\hline 56 & Uganda & Electoral Autocracy & Closed Autocracy & 1985 \\
\hline 57 & Fiji & Electoral Democracy & Closed Autocracy & 1987 \\
\hline 58 & Malawi & Electoral Autocracy & Closed Autocracy & 1987 \\
\hline 59 & Burundi & Electoral Autocracy & Closed Autocracy & 1988 \\
\hline 60 & Haiti & Electoral Autocracy & Closed Autocracy & 1989 \\
\hline
\end{tabular}


Table 8: Adverse Regime Transitions - 1970-2018 (cont.)

\begin{tabular}{|c|c|c|c|c|}
\hline & $\begin{array}{l}\text { Country } \\
\text { Name }\end{array}$ & $\begin{array}{l}\text { RoW Classification } \\
\text { before ART }\end{array}$ & $\begin{array}{l}\text { RoW Classification } \\
\text { after ART }\end{array}$ & $\begin{array}{r}\text { Year of } \\
\text { ART }\end{array}$ \\
\hline 61 & Dominican Republic & Electoral Democracy & Electoral Autocracy & 1990 \\
\hline 62 & Liberia & Electoral Autocracy & Closed Autocracy & 1990 \\
\hline 63 & Solomon Islands & Electoral Democracy & Electoral Autocracy & 1990 \\
\hline 64 & Sudan & Electoral Autocracy & Closed Autocracy & 1990 \\
\hline 65 & The Gambia & Electoral Democracy & Electoral Autocracy & 1990 \\
\hline 66 & Laos & Electoral Autocracy & Closed Autocracy & 1991 \\
\hline 67 & Thailand & Electoral Autocracy & Closed Autocracy & 1991 \\
\hline 68 & Estonia & Electoral Democracy & Electoral Autocracy & 1992 \\
\hline 69 & Haiti & Electoral Autocracy & Closed Autocracy & 1992 \\
\hline 70 & Papua New Guinea & Electoral Democracy & Electoral Autocracy & 1992 \\
\hline 71 & Peru & Electoral Democracy & Closed Autocracy & 1992 \\
\hline 72 & Angola & Electoral Autocracy & Closed Autocracy & 1993 \\
\hline 73 & Sierra Leone & Electoral Autocracy & Closed Autocracy & 1993 \\
\hline 74 & Nigeria & Electoral Autocracy & Closed Autocracy & 1994 \\
\hline 75 & Uganda & Electoral Autocracy & Closed Autocracy & 1994 \\
\hline 76 & Armenia & Electoral Democracy & Electoral Autocracy & 1995 \\
\hline 77 & Lesotho & Electoral Autocracy & Closed Autocracy & 1995 \\
\hline 78 & The Gambia & Electoral Autocracy & Closed Autocracy & 1995 \\
\hline 79 & Burundi & Electoral Autocracy & Closed Autocracy & 1996 \\
\hline 80 & Niger & Electoral Democracy & Electoral Autocracy & 1996 \\
\hline 81 & Russia & Electoral Democracy & Electoral Autocracy & 1996 \\
\hline 82 & Belarus & Electoral Democracy & Electoral Autocracy & 1997 \\
\hline 83 & El Salvador & Electoral Democracy & Electoral Autocracy & 1997 \\
\hline 84 & Republic of the Congo & Electoral Autocracy & Closed Autocracy & 1997 \\
\hline 85 & Zambia & Electoral Democracy & Electoral Autocracy & 1997 \\
\hline 86 & Sierra Leone & Electoral Autocracy & Closed Autocracy & 1998 \\
\hline 87 & Ukraine & Electoral Democracy & Electoral Autocracy & 1998 \\
\hline 88 & Burkina Faso & Electoral Democracy & Electoral Autocracy & 1999 \\
\hline 89 & Croatia & Electoral Democracy & Electoral Autocracy & 1999 \\
\hline 90 & Lesotho & Electoral Autocracy & Closed Autocracy & 1999 \\
\hline 91 & Pakistan & Electoral Autocracy & Closed Autocracy & 1999 \\
\hline 92 & Comoros & Electoral Autocracy & Closed Autocracy & 2000 \\
\hline 93 & Fiji & Electoral Democracy & Closed Autocracy & 2000 \\
\hline 94 & Iraq & Electoral Autocracy & Closed Autocracy & 2000 \\
\hline 95 & Macedonia & Electoral Democracy & Electoral Autocracy & 2000 \\
\hline 96 & Solomon Islands & Electoral Democracy & Electoral Autocracy & 2000 \\
\hline 97 & Thailand & Electoral Democracy & Electoral Autocracy & 2000 \\
\hline
\end{tabular}


Table 8: Adverse Regime Transitions - 1970-2018 (cont.)

\begin{tabular}{|c|c|c|c|c|}
\hline & $\begin{array}{l}\text { Country } \\
\text { Name }\end{array}$ & $\begin{array}{l}\text { RoW Classification } \\
\text { before ART }\end{array}$ & $\begin{array}{l}\text { RoW Classification } \\
\text { after ART }\end{array}$ & $\begin{array}{r}\text { Year of } \\
\text { ART }\end{array}$ \\
\hline 98 & Madagascar & Electoral Democracy & Electoral Autocracy & 2001 \\
\hline 99 & Tanzania & Electoral Democracy & Electoral Autocracy & 2001 \\
\hline 100 & Nepal & Electoral Autocracy & Closed Autocracy & 2002 \\
\hline 101 & Burkina Faso & Electoral Democracy & Electoral Autocracy & 2003 \\
\hline 102 & Nigeria & Electoral Democracy & Electoral Autocracy & 2003 \\
\hline 103 & Central African Republic & Electoral Autocracy & Closed Autocracy & 2004 \\
\hline 104 & Liberia & Electoral Autocracy & Closed Autocracy & 2004 \\
\hline 105 & Malawi & Electoral Democracy & Electoral Autocracy & 2004 \\
\hline 106 & Philippines & Electoral Democracy & Electoral Autocracy & 2004 \\
\hline 107 & Haiti & Electoral Autocracy & Closed Autocracy & 2005 \\
\hline 108 & Kosovo & Electoral Democracy & Electoral Autocracy & 2005 \\
\hline 109 & Moldova & Electoral Democracy & Electoral Autocracy & 2005 \\
\hline 110 & Sri Lanka & Electoral Democracy & Electoral Autocracy & 2005 \\
\hline 111 & Zambia & Electoral Democracy & Electoral Autocracy & 2005 \\
\hline 112 & Bangladesh & Electoral Democracy & Electoral Autocracy & 2006 \\
\hline 113 & Hungary & Liberal Democracy & Electoral Democracy & 2006 \\
\hline 114 & Mauritania & Electoral Autocracy & Closed Autocracy & 2006 \\
\hline 115 & Montenegro & Electoral Democracy & Electoral Autocracy & 2006 \\
\hline 116 & Solomon Islands & Electoral Democracy & Electoral Autocracy & 2006 \\
\hline 117 & Thailand & Electoral Democracy & Closed Autocracy & 2006 \\
\hline 118 & Venezuela & Electoral Democracy & Electoral Autocracy & 2006 \\
\hline 119 & Bangladesh & Electoral Autocracy & Closed Autocr & 2007 \\
\hline 120 & Fiji & Electoral Democracy & Closed Autocracy & 2007 \\
\hline 121 & Nicaragua & Electoral Democracy & Electoral Autocracy & 2007 \\
\hline 122 & South Africa & Liberal Democracy & Electoral Democracy & 2007 \\
\hline 123 & Guinea-Bissau & Electoral Democracy & Electoral Autocracy & 2008 \\
\hline 124 & Madagascar & Electoral Democracy & Electoral Autocracy & 2008 \\
\hline 125 & Mauritania & Electoral Autocracy & Closed Autocracy & 2008 \\
\hline 126 & Moldova & Electoral Democracy & Electoral Autocracy & 2008 \\
\hline 127 & Guinea & Electoral Autocracy & Closed Autocracy & 2009 \\
\hline 128 & Honduras & Electoral Democracy & Electoral Autocracy & 2009 \\
\hline 129 & Niger & Electoral Democracy & Electoral Autocracy & 2009 \\
\hline 130 & Tanzania & Electoral Democracy & Electoral Autocracy & 2009 \\
\hline
\end{tabular}


Table 8: Adverse Regime Transitions - 1970-2018 (cont.)

\begin{tabular}{|c|c|c|c|c|}
\hline & $\begin{array}{l}\text { Country } \\
\text { Name }\end{array}$ & $\begin{array}{l}\text { RoW Classification } \\
\text { before ART }\end{array}$ & $\begin{array}{l}\text { RoW Classification } \\
\text { after ART }\end{array}$ & $\begin{array}{r}\text { Year of } \\
\text { ART }\end{array}$ \\
\hline 131 & Guinea-Bissau & Electoral Democracy & Electoral Autocracy & 2010 \\
\hline 132 & Hunga & & Electoral Democracy & \\
\hline 133 & Iraq & Electoral Democracy & Electoral Autocracy & 2010 \\
\hline 134 & Israel & Liberal Democracy & Electoral Democracy & 2010 \\
\hline 135 & Lebanon & Electoral Democracy & Electoral Autocracy & 2010 \\
\hline 136 & Madagascar & lectoral Autocracy & Closed Autocracy & 2010 \\
\hline 137 & Montenegro & lectoral Democracy & Electoral Autocracy & 2010 \\
\hline 138 & Niger & lectoral Autocracy & Closed Autocracy & 2010 \\
\hline 139 & Taiwan & iberal Democracy & Electoral Democracy & 2010 \\
\hline 140 & Togo & Electoral Democracy & Electoral Autocracy & 2010 \\
\hline 141 & Bangladesh & Electoral Democracy & Electoral Autocracy & 2012 \\
\hline 142 & Koso & toral Democracy & 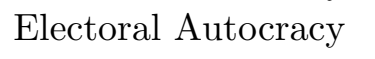 & 2012 \\
\hline 143 & Macedonia & toral Democracy & oral Autocr & 2012 \\
\hline 144 & Mali & ral Democracy & 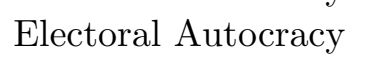 & 2012 \\
\hline 145 & Namibia & Dem & & 2012 \\
\hline 146 & Nepal & cy & toral Autocracy & 2012 \\
\hline 147 & Turkmenistan & ral Autocracy & Closed Autocracy & 2012 \\
\hline 148 & Ukraine & Electoral Democracy & Electoral Autocracy & 2012 \\
\hline 149 & & & & 2013 \\
\hline 150 & Guinea-Bissau & lectoral Autocracy & & 2013 \\
\hline 151 & Maldives & lectoral Democracy & Electoral Autocracy & 2013 \\
\hline 152 & & & & 2013 \\
\hline 153 & Slova & & & 2013 \\
\hline 154 & South Africa & Liberal Democracy & Electoral Democracy & 2013 \\
\hline 155 & Syria & Electoral Autocracy & Closed Autocracy & 2013 \\
\hline 156 & & & & 2013 \\
\hline 157 & Turkey & Electoral Democracy & Electoral Autocracy & 2013 \\
\hline 158 & & & & \\
\hline 159 & Libya & 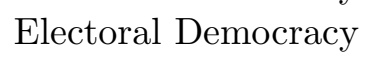 & & 2014 \\
\hline 160 & Thailand & Electoral Autocracy & Closed Autocracy & 2014 \\
\hline 161 & & & & 2015 \\
\hline 162 & Burkina Faso & Electoral Democracy & Electoral Autocracy & 2015 \\
\hline 163 & Comoros & & Electoral Autocracy & 2015 \\
\hline 164 & Ghana & Liberal Democracy & Electoral Democracy & 2015 \\
\hline 165 & Poland & Liberal Democracy & Electoral Democracy & 2015 \\
\hline 166 & Serbia & Electoral Democracy & Electoral Autocracy & 2015 \\
\hline 167 & Zambia & Electoral Democracy & Electoral Autocracy & 2015 \\
\hline
\end{tabular}


Table 8: Adverse Regime Transitions - 1970-2018 (cont.)

\begin{tabular}{|c|c|c|c|c|}
\hline & $\begin{array}{l}\text { Country } \\
\text { Name }\end{array}$ & $\begin{array}{l}\text { RoW Classification } \\
\text { before ART }\end{array}$ & $\begin{array}{l}\text { RoW Classification } \\
\text { after ART }\end{array}$ & $\begin{array}{r}\text { Year of } \\
\text { ART }\end{array}$ \\
\hline 168 & Fiji & Electoral Democracy & Electoral Autocracy & 2016 \\
\hline 169 & Kyrgyzstan & Electoral Democracy & Electoral Autocracy & 2016 \\
\hline 170 & Latvia & Liberal Democracy & Electoral Democracy & 2016 \\
\hline 171 & Lithuania & Liberal Democracy & Electoral Democracy & 2016 \\
\hline 172 & Montenegro & Electoral Democracy & Electoral Autocracy & 2016 \\
\hline 173 & Tanzania & Electoral Democracy & Electoral Autocracy & 2016 \\
\hline 174 & Vietnam & Electoral Autocracy & Closed Autocracy & 2016 \\
\hline 175 & Yemen & Electoral Autocracy & Closed Autocracy & 2016 \\
\hline 176 & & & & 2017 \\
\hline 177 & Botswana & Liberal Democracy & Electoral Democracy & 2017 \\
\hline 178 & Kenya & Electoral Democracy & Electoral Autocracy & 2017 \\
\hline 179 & Lesotho & Electoral Democracy & Electoral Autocr & 2017 \\
\hline 180 & Mauritius & Liberal Democracy & Electoral Democracy & 2017 \\
\hline 181 & Namibia & Liberal Democracy & Electoral Democracy & 2017 \\
\hline 182 & Togo & Electoral Democracy & Electoral Autocracy & 2017 \\
\hline 183 & Cape Verde & Liberal Democracy & Electoral Democracy & 2018 \\
\hline 184 & Chile & Liberal Democracy & Electoral Democracy & 2018 \\
\hline 185 & Greece & Liberal Democracy & Electoral Democracy & 2018 \\
\hline 186 & Guinea-Bissau & Electoral Democracy & Electoral Autocracy & 2018 \\
\hline 187 & Lebanon & Electoral Democracy & Electoral Autocracy & 2018 \\
\hline 188 & South Korea & Liberal Democracy & Electoral Democracy & 2018 \\
\hline 189 & Tunisia & Liberal Democracy & Electoral Democracy & 2018 \\
\hline
\end{tabular}




\section{E Appendix: Data Description}

The table below provides a list of all of the variables we use in our various models. Most variable names are simply the variable tag from the V-Dem data set. Please see the V-Dem code book for a full description of these variables. The other variable names are self explanatory. This table also provides basic descriptive statistics: the minimum and maximum value, the mean, and the standard deviation of each variable in our sample.

Table 9: Variables and Descriptive Statistics

\begin{tabular}{lrrrr}
\hline Variable & Min & Max & Mean & SD \\
\hline is_closed_autocracy & 0 & 1 & 0.306 & 0.461 \\
currentRegimeDuration & 1 & 118 & 26.417 & 28.042 \\
low_border_case & 0 & 1 & 0.139 & 0.346 \\
high_border_case & 0 & 1 & 0.113 & 0.316 \\
yrs_since_any_neg_change & 0 & 117 & 40.521 & 34.302 \\
num_of_neg_changes & 0 & 10 & 1.369 & 1.642 \\
any_neg_change & 0 & 1 & 0.024 & 0.154 \\
num_of_neg_changes_3yrs & 0 & 2 & 0.072 & 0.266 \\
num_of_neg_changes_5yrs & 0 & 2 & 0.120 & 0.345 \\
num_of_neg_changes_10yrs & 0 & 3 & 0.232 & 0.496 \\
was_neg_change_last_3yrs & 0 & 1 & 0.070 & 0.254 \\
was_neg_change_last_5yrs & 0 & 1 & 0.113 & 0.316 \\
was_neg_change_last_10yrs & 0 & 1 & 0.200 & 0.400 \\
v2x_regime.0 & 0 & 1 & 0.306 & 0.461 \\
v2x_regime.1 & 0 & 1 & 0.278 & 0.448 \\
v2x_regime.2 & 0 & 1 & 0.208 & 0.406 \\
v2x_regime.3 & 0 & 1 & 0.208 & 0.406 \\
v2x_regime_amb.0 & 0 & 1 & 0.267 & 0.442 \\
v2x_regime_amb.1 & 0 & 1 & 0.040 & 0.195 \\
v2x_regime_amb.2 & 0 & 1 & 0.029 & 0.169 \\
v2x_regime_amb.3 & 0 & 1 & 0.212 & 0.409 \\
v2x_regime_amb.4 & 0 & 1 & 0.037 & 0.188 \\
v2x_regime_amb.5 & 0 & 1 & 0.049 & 0.217 \\
v2x_regime_amb.6 & 0 & 1 & 0.123 & 0.328 \\
v2x_regime_amb.7 & 0 & 1 & 0.036 & 0.187 \\
v2x_regime_amb.8 & 0 & 1 & 0.060 & 0.238 \\
v2x_regime_amb.9 & 0 & 1 & 0.147 & 0.354 \\
\hline & & & & \\
& & &
\end{tabular}


Table 9: Variables and Descriptive Statistics (cont.)

\begin{tabular}{lrrrr}
\hline Variable & Min & Max & Mean & SD \\
\hline is_leg & 0 & 1 & 0.912 & 0.284 \\
is_elec & 0 & 1 & 0.854 & 0.353 \\
is_election_year & 0 & 1 & 0.261 & 0.439 \\
v2elrgstry & -3.967 & 2.872 & 0.286 & 1.313 \\
v2elvotbuy & -2.989 & 3.400 & 0.033 & 1.351 \\
v2elirreg & -3.081 & 3.109 & 0.041 & 1.369 \\
v2elintim & -4.037 & 3.445 & -0.055 & 1.458 \\
v2elpeace & -4.578 & 2.550 & 0.121 & 1.302 \\
v2elfrfair & -3.410 & 2.883 & -0.037 & 1.527 \\
v2elmulpar & -3.534 & 2.538 & 0.080 & 1.476 \\
v2elboycot & -4.317 & 1.927 & 0.078 & 1.228 \\
v2elaccept & -3.805 & 2.687 & -0.062 & 1.362 \\
v2elasmoff & -6.669 & 0.885 & -0.076 & 1.066 \\
v2eldonate & -2.561 & 3.895 & -0.227 & 1.332 \\
v2elpubfin & -2.586 & 3.770 & -0.025 & 1.451 \\
v2ellocons & 0 & 59 & 8.052 & 8.907 \\
v2ellocumul & 0 & 59 & 14.617 & 10.428 \\
v2elprescons & 0 & 30 & 2.673 & 4.326 \\
v2elprescumul & 0 & 36 & 4.807 & 6.696 \\
v2elpaidig & -2.580 & 3.161 & 0.056 & 1.328 \\
v2elfrcamp & -2.241 & 2.946 & 0.346 & 1.360 \\
v2elpdcamp & -2.727 & 3.385 & 0.058 & 1.391 \\
v2elmonref & 0 & 1 & 0.029 & 0.168 \\
v2elmonden & 0 & 1 & 0.025 & 0.156 \\
v2x_polyarchy & 0.010 & 0.948 & 0.447 & 0.290 \\
v2x_freexp_altinf & 0.012 & 0.990 & 0.569 & 0.331 \\
v2x_frassoc_thick & 0.019 & 0.957 & 0.547 & 0.340 \\
v2xel_frefair & 0 & 0.993 & 0.469 & 0.347 \\
v2x_elecoff & 0 & 1 & 0.762 & 0.411 \\
v2x_liberal & 0.004 & 0.985 & 0.534 & 0.292 \\
v2xcl_rol & 0 & 0.994 & 0.602 & 0.300 \\
v2x_jucon & 0.003 & 0.991 & 0.534 & 0.310 \\
v2xlg_legcon & 0 & 0.984 & 0.470 & 0.345 \\
v2x_partip & 0.018 & 0.887 & 0.408 & 0.207 \\
v2x_cspart & 0.021 & 0.989 & 0.575 & 0.283 \\
v2xdl_delib & 0.009 & 0.988 & 0.555 & 0.300 \\
& 0.054 & 0.983 & 0.588 & 0.227 \\
v2x_egal & 0.011 & 0.992 & 0.611 & 0.258 \\
v2xequaccess & 0.025 & 0.991 & 0.580 & 0.246 \\
\hline
\end{tabular}


Table 9: Variables and Descriptive Statistics (cont.)

\begin{tabular}{lrrrr}
\hline Variable & Min & Max & Mean & SD \\
\hline v2xeg_eqdr & 0.010 & 0.985 & 0.578 & 0.283 \\
v2elembaut & -2.642 & 3.818 & 0.311 & 1.706 \\
v2elembcap & -3.002 & 3.654 & 0.415 & 1.488 \\
v2elreggov & 0 & 1 & 0.778 & 0.416 \\
v2ellocgov & 0 & 1 & 0.958 & 0.200 \\
v2elrsthos & 0 & 1 & 0.879 & 0.326 \\
v2elrstrct & 0 & 1 & 0.905 & 0.293 \\
v2psparban & -3.700 & 2.891 & 0.265 & 1.792 \\
v2psbars & -3.735 & 3.091 & 0.476 & 1.708 \\
v2psoppaut & -3.542 & 3.534 & 0.369 & 1.944 \\
v2psorgs & -3.097 & 3.213 & 0.671 & 1.405 \\
v2psprbrch & -3.191 & 3.545 & 0.658 & 1.369 \\
v2psprlnks & -3.205 & 3.509 & 0.113 & 1.382 \\
v2psplats & -3.163 & 3.349 & 0.379 & 1.635 \\
v2pscnslnl & -2.685 & 4.606 & 0.140 & 1.357 \\
v2pscohesv & -3.690 & 2.557 & 0.691 & 1.219 \\
v2pscomprg & -3.467 & 2.582 & 0.457 & 1.199 \\
v2psnatpar & -2.772 & 3.017 & 0.125 & 1.415 \\
v2pssunpar & -2.751 & 2.798 & -0.010 & 1.594 \\
v2exremhsp & -2.495 & 4.164 & -0.315 & 1.199 \\
v2exdfdshs & -3.490 & 3.029 & -0.178 & 1.502 \\
v2exdfcbhs & -3.377 & 2.456 & 0.184 & 1.497 \\
v2exdfvths & -3.396 & 2.525 & -0.091 & 1.496 \\
v2exdfdmhs & -3.281 & 2.402 & 0.159 & 1.637 \\
v2exdfpphs & -2.553 & 3.328 & 0.327 & 1.477 \\
v2exhoshog & 0 & 1 & 0.399 & 0.490 \\
v2exrescon & -3.223 & 3.476 & 0.293 & 1.429 \\
v2exbribe & -3.142 & 3.607 & 0.012 & 1.537 \\
v2exembez & -3.232 & 3.570 & 0.050 & 1.544 \\
v2excrptps & -3.074 & 4.005 & -0.150 & 1.505 \\
v2exthftps & -3.142 & 3.712 & 0.049 & 1.518 \\
v2ex_elechos & 0 & 1 & 0.460 & 0.498 \\
v2ex_hogw & 0 & 1 & 0.381 & 0.471 \\
v2expathhs & 0 & 8 & 5.208 & 2.380 \\
v2lgbicam & 0 & 2 & 1.251 & 0.604 \\
v2lgqstexp & -2.336 & 2.320 & 0.248 & 1.336 \\
v2lginvstp & -2.939 & 3.844 & 0.217 & 1.481 \\
v2lgotovst & -2.974 & 3.124 & 0.181 & 1.397 \\
v2lgcrrpt & -3.284 & 3.322 & -0.087 & 1.321 \\
v2lgoppart & -2.528 & 3.507 & 0.285 & 1.582 \\
v2lgfunds & -2.427 & 2.418 & 0.214 & 1.291 \\
v2lgdsadlobin & -9.368 & 0.605 & -0.063 & 0.975 \\
& -3.778 & 1.963 & 0.352 & 1.196 \\
v2legplo & -3.627 & 3.742 & 0.632 & 1.097 \\
& & & & \\
\hline
\end{tabular}


Table 9: Variables and Descriptive Statistics (cont.)

\begin{tabular}{|c|c|c|c|c|}
\hline Variable & Min & Max & Mean & $\mathrm{SD}$ \\
\hline v2ex_hosw & 0 & 1 & 0.619 & 0.471 \\
\hline v2lgamend & 0 & 1 & 0.426 & 0.495 \\
\hline v2dlreason & -2.911 & 3.716 & 0.439 & 1.347 \\
\hline v2dlcommon & -3.568 & 2.858 & 0.409 & 1.188 \\
\hline v2dlcountr & -3.359 & 3.548 & 0.201 & 1.435 \\
\hline v2dlconslt & -3.051 & 4.455 & 0.555 & 1.414 \\
\hline v2dlengage & -3.123 & 3.457 & 0.460 & 1.426 \\
\hline v2dlencmps & -3.452 & 3.438 & 0.545 & 1.238 \\
\hline v2dlunivl & -3.289 & 3.407 & 0.661 & 1.142 \\
\hline v2jureform & -3.607 & 3.398 & 0.024 & 1.167 \\
\hline v2jupurge & -3.830 & 2.847 & 0.427 & 1.262 \\
\hline v2jupoatck & -4.449 & 3.048 & 0.334 & 1.230 \\
\hline v2jupack & -4.454 & 1.710 & -0.056 & 1.242 \\
\hline v2juaccnt & -3.087 & 3.642 & 0.495 & 1.278 \\
\hline v2jucorrdc & -3.161 & 3.290 & 0.043 & 1.512 \\
\hline v2juhcind & -3.205 & 3.471 & 0.100 & 1.469 \\
\hline v2juncind & -3.375 & 3.359 & 0.259 & 1.470 \\
\hline v2juhccomp & -3.910 & 2.875 & 0.281 & 1.468 \\
\hline v2jucomp & -3.458 & 3.264 & 0.206 & 1.471 \\
\hline v2jureview & -2.719 & 1.842 & 0.180 & 1.241 \\
\hline v2clacfree & -3.506 & 3.798 & 0.617 & 1.669 \\
\hline v2clrelig & -3.929 & 2.798 & 0.632 & 1.468 \\
\hline v2cltort & -3.067 & 3.658 & 0.388 & 1.631 \\
\hline v2clkill & -3.511 & 3.514 & 0.638 & 1.667 \\
\hline v2cltrnslw & -3.730 & 4.170 & 0.476 & 1.534 \\
\hline v2clrspct & -3.685 & 4.455 & 0.202 & 1.512 \\
\hline v2clfmove & -4.206 & 2.949 & 0.645 & 1.474 \\
\hline v2cldmovem & -5.016 & 2.689 & 0.745 & 1.288 \\
\hline v2cldmovew & -4.756 & 3.238 & 0.696 & 1.402 \\
\hline v2cldiscm & -3.781 & 3.880 & 0.508 & 1.681 \\
\hline v2cldiscw & -3.534 & 3.500 & 0.493 & 1.582 \\
\hline v2clslavem & -4.100 & 3.033 & 0.883 & 1.130 \\
\hline v2clslavef & -4.281 & 2.973 & 0.682 & 1.119 \\
\hline v2clstown & -4.197 & 3.295 & 0.107 & 1.365 \\
\hline v2clprptym & -4.398 & 2.425 & 0.643 & 1.267 \\
\hline v2clprptyw & -3.750 & 2.822 & 0.609 & 1.337 \\
\hline v2clacjstm & -4.056 & 3.896 & 0.546 & 1.476 \\
\hline v2clacjstw & -3.974 & 3.722 & 0.492 & 1.466 \\
\hline v2clacjust & -2.897 & 3.594 & 0.836 & 1.197 \\
\hline v2clsocgrp & -2.996 & 3.102 & 0.526 & 1.305 \\
\hline v2clrgunev & -2.942 & 2.794 & 0.347 & 1.301 \\
\hline v2svdomaut & -3.254 & 2.169 & 1.036 & 0.730 \\
\hline v2svinlaut & -3.147 & 2.733 & 1.097 & 0.769 \\
\hline v2svstterr & 33.750 & 100 & 91.271 & 10.554 \\
\hline v2cseeorgs & -3.226 & 3.548 & 0.498 & 1.592 \\
\hline
\end{tabular}


Table 9: Variables and Descriptive Statistics (cont.)

\begin{tabular}{|c|c|c|c|c|}
\hline Variable & Min & Max & Mean & $\mathrm{SD}$ \\
\hline v2csreprss & -3.729 & 3.379 & 0.504 & 1.628 \\
\hline v2cscnsult & -2.454 & 3.848 & 0.400 & 1.476 \\
\hline v2csprtcpt & -3.532 & 3.263 & 0.333 & 1.470 \\
\hline v2csgender & -3.499 & 3.238 & 0.788 & 1.087 \\
\hline v2csantimv & -2.973 & 4.015 & -0.515 & 1.265 \\
\hline v2csrlgrep & -4.121 & 2.885 & 0.579 & 1.455 \\
\hline v2csrlgcon & -2.854 & 3.054 & 0.159 & 1.335 \\
\hline v2mecenefm & -3.089 & 3.569 & 0.220 & 1.671 \\
\hline v2mecrit & -3.314 & 3.595 & 0.347 & 1.698 \\
\hline v2merange & -3.111 & 3.171 & 0.285 & 1.629 \\
\hline v2meharjrn & -3.088 & 3.985 & 0.284 & 1.628 \\
\hline v2meslfcen & -3.241 & 3.268 & 0.211 & 1.553 \\
\hline v2mebias & -3.585 & 3.732 & 0.264 & 1.702 \\
\hline v2mecorrpt & -3.179 & 3.456 & 0.162 & 1.645 \\
\hline v2pepwrses & -2.950 & 2.988 & 0.478 & 1.141 \\
\hline v2pepwrsoc & -2.638 & 3.399 & 0.543 & 1.269 \\
\hline v2pepwrgen & -2.884 & 3.876 & 0.545 & 1.199 \\
\hline v2pepwrort & -2.204 & 3.485 & -0.170 & 1.242 \\
\hline v2peedueq & -3.102 & 3.634 & 0.398 & 1.482 \\
\hline v2pehealth & -3.271 & 3.689 & 0.434 & 1.503 \\
\hline v2x_accountability & -1.981 & 2.175 & 0.352 & 1.020 \\
\hline v2x_veracc & -1.579 & 1.893 & 0.415 & 0.877 \\
\hline v2x_diagacc & -2.145 & 2.178 & 0.364 & 1.046 \\
\hline v2x_horacc & -2.144 & 2.385 & 0.194 & 1.048 \\
\hline v2xex_elecleg & 0 & 1 & 0.840 & 0.335 \\
\hline v2x_civlib & 0.009 & 0.978 & 0.596 & 0.288 \\
\hline v2x_clphy & 0.013 & 0.987 & 0.580 & 0.312 \\
\hline v2x_clpol & 0.009 & 0.987 & 0.580 & 0.334 \\
\hline v2x_clpriv & 0 & 0.973 & 0.630 & 0.287 \\
\hline v2x_corr & 0.006 & 0.976 & 0.513 & 0.296 \\
\hline v2x_EDcomp_thick & 0.002 & 0.958 & 0.509 & 0.287 \\
\hline v2x_elecreg & 0 & 1 & 0.854 & 0.353 \\
\hline v2x_freexp & 0.011 & 0.991 & 0.570 & 0.324 \\
\hline v2x_gencl & 0.001 & 0.985 & 0.612 & 0.273 \\
\hline v2x_gencs & 0.014 & 0.975 & 0.603 & 0.246 \\
\hline v2x_hosabort & 0 & 1 & 0.002 & 0.039 \\
\hline v2x_hosinter & 0 & 1 & 0.008 & 0.090 \\
\hline v2x_pubcorr & 0.004 & 0.979 & 0.491 & 0.300 \\
\hline v2x_rule & 0.005 & 0.998 & 0.520 & 0.310 \\
\hline v2xcl_acjst & 0.002 & 0.995 & 0.582 & 0.286 \\
\hline v2xcl_disc & 0.007 & 0.992 & 0.584 & 0.315 \\
\hline v2xcl_dmove & 0 & 0.970 & 0.634 & 0.262 \\
\hline v2xcl_prpty & 0.002 & 0.949 & 0.600 & 0.269 \\
\hline v2xcl_slave & 0.001 & 0.969 & 0.635 & 0.240 \\
\hline v2xcs_ccsi & 0.008 & 0.977 & 0.576 & 0.314 \\
\hline
\end{tabular}


Table 9: Variables and Descriptive Statistics (cont.)

\begin{tabular}{|c|c|c|c|c|}
\hline Variable & Min & $\operatorname{Max}$ & Mean & $\mathrm{SD}$ \\
\hline v2xel_elecparl & 0 & 1 & 0.216 & 0.412 \\
\hline v2xel_elecpres & 0 & 1 & 0.103 & 0.305 \\
\hline v2xex_elecreg & 0 & 1 & 0.488 & 0.500 \\
\hline v2xlg_elecreg & 0 & 1 & 0.852 & 0.355 \\
\hline v2x_ex_confidence & 0 & 1 & 0.329 & 0.378 \\
\hline v2x_ex_direlect & 0 & 1 & 0.366 & 0.475 \\
\hline v2x_ex_hereditary & 0 & 1 & 0.043 & 0.159 \\
\hline v2x_ex_military & 0 & 1 & 0.185 & 0.236 \\
\hline v2x_ex_party & 0 & 1 & 0.148 & 0.210 \\
\hline v2x_execorr & 0.011 & 0.978 & 0.494 & 0.301 \\
\hline v2x_legabort & 0 & 1 & 0.002 & 0.042 \\
\hline v2xlg_leginter & 0 & 1 & 0.020 & 0.140 \\
\hline v2x_neopat & 0.006 & 0.990 & 0.508 & 0.308 \\
\hline v2xnp_client & 0.012 & 0.986 & 0.485 & 0.259 \\
\hline v2xnp_pres & 0.010 & 0.989 & 0.471 & 0.322 \\
\hline v2xnp_regcorr & 0.006 & 0.980 & 0.499 & 0.304 \\
\hline diff_year_prior_v2elrgstry & -2.725 & 3.553 & 0.015 & 0.232 \\
\hline diff_year_prior_v2elvotbuy & -2.877 & 2.771 & -0.002 & 0.241 \\
\hline diff_year_prior_v2elirreg & -3.293 & 3.108 & 0.005 & 0.274 \\
\hline diff_year_prior_v2elintim & -3.299 & 4.569 & 0.013 & 0.296 \\
\hline diff_year_prior_v2elpeace & -3.617 & 3.779 & 0.004 & 0.295 \\
\hline diff_year_prior_v2elfrfair & -3.669 & 4.702 & 0.014 & 0.337 \\
\hline diff_year_prior_v2elmulpar & -4.258 & 4.612 & 0.022 & 0.345 \\
\hline diff_year_prior_v2elboycot & -4.780 & 4.759 & 0.004 & 0.379 \\
\hline diff_year_prior_v2elaccept & -4.225 & 4.246 & 0.009 & 0.328 \\
\hline diff_year_prior_v2elasmoff & -7.222 & 6.927 & 0.005 & 0.398 \\
\hline diff_year_prior_v2eldonate & -2.113 & 3.169 & 0.034 & 0.215 \\
\hline diff_year_prior_v2elpubfin & -1.543 & 3.918 & 0.024 & 0.215 \\
\hline diff_year_prior_v2ellocons & -25 & 3 & 0.149 & 0.933 \\
\hline diff_year_prior_v2ellocumul & 0 & 3 & 0.231 & 0.463 \\
\hline diff_year_prior_v2elprescons & -19 & 3 & 0.095 & 0.576 \\
\hline diff_year_prior_v2elprescumul & 0 & 3 & 0.126 & 0.395 \\
\hline diff_year_prior_v2elpaidig & -3.108 & 4.137 & 0.018 & 0.258 \\
\hline diff_year_prior_v2elfrcamp & -3.996 & 4.508 & 0.023 & 0.294 \\
\hline diff_year_prior_v2elpdcamp & -2.968 & 3.695 & 0.021 & 0.267 \\
\hline diff_year_prior_v2elmonref & -1 & 1 & 0.001 & 0.104 \\
\hline diff_year_prior_v2elmonden & -1 & 1 & 0.001 & 0.092 \\
\hline diff_year_prior_v2x_polyarchy & -0.475 & 0.702 & 0.005 & 0.046 \\
\hline diff_year_prior_v2x_freexp_altinf & -0.571 & 0.848 & 0.005 & 0.057 \\
\hline diff_year_prior_v2x_frassoc_thick & -0.669 & 0.827 & 0.006 & 0.060 \\
\hline diff_year_prior_v2xel_frefair & -0.865 & 0.919 & 0.005 & 0.083 \\
\hline diff_year_prior_v2x_elecoff & -1 & 1 & 0.006 & 0.169 \\
\hline diff_year_prior_v2x_liberal & -0.474 & 0.653 & 0.004 & 0.047 \\
\hline
\end{tabular}


Table 9: Variables and Descriptive Statistics (cont.)

\begin{tabular}{|c|c|c|c|c|}
\hline Variable & Min & Max & Mean & $\mathrm{SD}$ \\
\hline diff_year_prior_v2xcl_rol & -0.532 & 0.750 & 0.004 & 0.046 \\
\hline diff_year_prior_v2x_jucon & -0.622 & 0.822 & 0.002 & 0.050 \\
\hline diff_year_prior_v2xlg_legcon & -0.868 & 0.939 & 0.005 & 0.092 \\
\hline diff_year_prior_v2x_partip & -0.356 & 0.525 & 0.004 & 0.033 \\
\hline diff_year_prior_v2x_cspart & -0.508 & 0.711 & 0.006 & 0.052 \\
\hline diff_year_prior_v2xdl_delib & -0.667 & 0.821 & 0.005 & 0.061 \\
\hline diff_year_prior_v2x_egal & -0.240 & 0.438 & 0.002 & 0.032 \\
\hline diff_year_prior_v2xeg_eqprotec & -0.545 & 0.662 & 0.002 & 0.038 \\
\hline diff_year_prior_v2xeg_eqaccess & -0.340 & 0.553 & 0.003 & 0.040 \\
\hline diff_year_prior_v2xeg_eqdr & -0.354 & 0.520 & 0.001 & 0.031 \\
\hline diff_year_prior_v2elembaut & -3.086 & 3.922 & 0.025 & 0.272 \\
\hline diff_year_prior_v2elembcap & -2.259 & 3.904 & 0.017 & 0.216 \\
\hline diff_year_prior_v2elreggov & -1 & 1 & 0.001 & 0.045 \\
\hline diff_year_prior_v2ellocgov & -1 & 1 & 0.001 & 0.038 \\
\hline diff_year_prior_v2elrsthos & -1 & 1 & -0.002 & 0.083 \\
\hline diff_year_prior_v2elrstrct & -1 & 1 & 0.001 & 0.062 \\
\hline diff_year_prior_v2psparban & -4.146 & 4.752 & 0.031 & 0.361 \\
\hline diff_year_prior_v2psbars & -3.495 & 4.394 & 0.027 & 0.319 \\
\hline diff_year_prior_v2psoppaut & -3.628 & 4.485 & 0.027 & 0.345 \\
\hline diff_year_prior_v2psorgs & -3.490 & 3.654 & 0.013 & 0.236 \\
\hline diff_year_prior_v2psprbrch & -3.340 & 3.156 & 0.008 & 0.222 \\
\hline diff_year_prior_v2psprlnks & -2.672 & 2.899 & 0.010 & 0.209 \\
\hline diff_year_prior_v2psplats & -2.524 & 3.900 & 0.014 & 0.222 \\
\hline diff_year_prior_v2pscnslnl & -3.354 & 3.022 & 0.018 & 0.216 \\
\hline diff_year_prior_v2pscohesv & -1.992 & 2.384 & 0 & 0.195 \\
\hline diff_year_prior_v2pscomprg & -3.269 & 3.627 & 0.005 & 0.224 \\
\hline diff_year_prior_v2psnatpar & -3.754 & 2.976 & -0.003 & 0.357 \\
\hline diff_year_prior_v2pssunpar & -3.920 & 4.109 & 0.019 & 0.272 \\
\hline diff_year_prior_v2exremhsp & -3.736 & 3.063 & 0.006 & 0.279 \\
\hline diff_year_prior_v2exdfdshs & -4.133 & 2.845 & -0.009 & 0.265 \\
\hline diff_year_prior_v2exdfcbhs & -3.227 & 3.322 & -0.003 & 0.231 \\
\hline diff_year_prior_v2exdfvths & -3.028 & 3.279 & -0.007 & 0.236 \\
\hline diff_year_prior_v2exdfdmhs & -3.283 & 3.039 & -0.005 & 0.238 \\
\hline diff_year_prior_v2exdfpphs & -2.655 & 4.069 & 0.010 & 0.225 \\
\hline diff_year_prior_v2exhoshog & -1 & 1 & -0.002 & 0.148 \\
\hline diff_year_prior_v2exrescon & -3.962 & 5.174 & 0.007 & 0.291 \\
\hline diff_year_prior_v2exbribe & -3.809 & 3.285 & -0.001 & 0.237 \\
\hline diff_year_prior_v2exembez & -2.847 & 3.119 & -0.001 & 0.243 \\
\hline diff_year_prior_v2excrptps & -2.522 & 2.919 & -0.006 & 0.191 \\
\hline diff_year_prior_v2exthftps & -2.650 & 2.803 & -0.005 & 0.211 \\
\hline diff_year_prior_v2ex_elechos & -1 & 1 & 0.009 & 0.168 \\
\hline diff_year_prior_v2ex_hogw & -1 & 1 & 0.001 & 0.105 \\
\hline diff_year_prior_v2expathhs & -8 & 8 & 0.038 & 1.002 \\
\hline diff_year_prior_v2lgbicam & -2 & 2 & 0.006 & 0.272 \\
\hline diff_year_prior_v2lgqstexp & -2.148 & 4.149 & 0.014 & 0.329 \\
\hline
\end{tabular}


Table 9: Variables and Descriptive Statistics (cont.)

\begin{tabular}{|c|c|c|c|c|}
\hline Variable & Min & Max & Mean & $\mathrm{SD}$ \\
\hline diff_year_prior_v2lginvstp & -2.661 & 3.769 & 0.015 & 0.337 \\
\hline diff_year_prior_v2lgotovst & -2.886 & 3.431 & 0.015 & 0.322 \\
\hline diff_year_prior_v2lgcrrpt & -3.966 & 3.941 & -0.008 & 0.305 \\
\hline diff_year_prior_v2lgoppart & -2.730 & 4.508 & 0.017 & 0.366 \\
\hline diff_year_prior_v2lgfunds & -3.582 & 3.419 & 0.015 & 0.303 \\
\hline diff_year_prior_v2lgdsadlobin & -9.368 & 9.852 & 0.001 & 0.330 \\
\hline diff_year_prior_v2lglegplo & -3.600 & 4.463 & 0.011 & 0.310 \\
\hline diff_year_prior_v2lgcomslo & -3.627 & 4.796 & 0.021 & 0.288 \\
\hline diff_year_prior_v2lgsrvlo & -3.173 & 2.313 & -0.006 & 0.277 \\
\hline diff_year_prior_v2ex_hosw & -1 & 1 & -0.001 & 0.105 \\
\hline diff_year_prior_v2lgamend & -1 & 1 & 0.002 & 0.134 \\
\hline diff_year_prior_v2dlreason & -3.349 & 3.548 & 0.020 & 0.285 \\
\hline diff_year_prior_v2dlcommon & -2.238 & 3.033 & 0.013 & 0.248 \\
\hline diff_year_prior_v2dlcountr & -3.128 & 5.167 & 0.019 & 0.320 \\
\hline diff_year_prior_v2dlconslt & -3.315 & 4.817 & 0.020 & 0.312 \\
\hline diff_year_prior_v2dlengage & -3.446 & 3.811 & 0.023 & 0.306 \\
\hline diff_year_prior_v2dlencmps & -2.989 & 2.427 & 0.009 & 0.240 \\
\hline diff_year_prior_v2dlunivl & -3.384 & 4.001 & 0.007 & 0.215 \\
\hline diff_year_prior_v2jureform & -4.809 & 4.615 & 0.005 & 0.518 \\
\hline diff_year_prior_v2jupurge & -3.846 & 2.964 & 0.012 & 0.338 \\
\hline diff_year_prior_v2jupoatck & -4.557 & 3.449 & -0.003 & 0.321 \\
\hline diff_year_prior_v2jupack & -3.524 & 3.724 & 0.007 & 0.311 \\
\hline diff_year_prior_v2juaccnt & -3.485 & 2.514 & 0.009 & 0.212 \\
\hline diff_year_prior_v2jucorrdc & -2.798 & 2.921 & -0.005 & 0.184 \\
\hline diff_year_prior_v2juhcind & -2.791 & 4.524 & 0.012 & 0.265 \\
\hline diff_year_prior_v2juncind & -2.590 & 4.365 & 0.009 & 0.238 \\
\hline diff_year_prior_v2juhccomp & -2.630 & 3.685 & 0.006 & 0.225 \\
\hline diff_year_prior_v2jucomp & -3.511 & 3.540 & 0.006 & 0.224 \\
\hline diff_year_prior_v2jureview & -2.607 & 3.391 & 0.021 & 0.238 \\
\hline diff_year_prior_v2clacfree & -4.323 & 4.146 & 0.021 & 0.304 \\
\hline diff_year_prior_v2clrelig & -3.592 & 3.765 & 0.014 & 0.234 \\
\hline diff_year_prior_v2cltort & -3.661 & 3.753 & 0.021 & 0.295 \\
\hline diff_year_prior_v2clkill & -3.669 & 4.046 & 0.021 & 0.308 \\
\hline diff_year_prior_v2cltrnslw & -3.800 & 3.261 & 0.013 & 0.262 \\
\hline diff_year_prior_v2clrspct & -3.727 & 4.213 & 0.007 & 0.252 \\
\hline diff_year_prior_v2clfmove & -3.426 & 4.747 & 0.021 & 0.259 \\
\hline diff_year_prior_v2cldmovem & -4.805 & 5.435 & 0.015 & 0.247 \\
\hline diff_year_prior_v2cldmovew & -4.651 & 4.495 & 0.017 & 0.222 \\
\hline diff_year_prior_v2cldiscm & -3.696 & 4.530 & 0.025 & 0.325 \\
\hline diff_year_prior_v2cldiscw & -3.274 & 4.009 & 0.025 & 0.297 \\
\hline diff_year_prior_v2clslavem & -4.915 & 2.737 & 0.010 & 0.184 \\
\hline diff_year_prior_v2clslavef & -4.019 & 3.731 & 0.010 & 0.176 \\
\hline diff_year_prior_v2clstown & -3.472 & 4.145 & 0.024 & 0.240 \\
\hline diff_year_prior_v2clprptym & -3.345 & 4.414 & 0.020 & 0.190 \\
\hline diff_year_prior_v2clprptyw & -3.907 & 3.834 & 0.022 & 0.183 \\
\hline
\end{tabular}


Table 9: Variables and Descriptive Statistics (cont.)

\begin{tabular}{|c|c|c|c|c|}
\hline Variable & Min & $\operatorname{Max}$ & Mean & $\mathrm{SD}$ \\
\hline diff_year_prior_v2clacjstm & -4.656 & 2.962 & 0.015 & 0.229 \\
\hline diff_year_prior_v2clacjstw & -4.210 & 2.785 & 0.016 & 0.218 \\
\hline diff_year_prior_v2clacjust & -3.102 & 3.390 & 0.009 & 0.185 \\
\hline diff_year_prior_v2clsocgrp & -2.108 & 2.766 & 0.013 & 0.184 \\
\hline diff_year_prior_v2clrgunev & -3.059 & 2.875 & 0.002 & 0.206 \\
\hline diff_year_prior_v2svdomaut & -1.845 & 4.574 & 0.013 & 0.219 \\
\hline diff_year_prior_v2svinlaut & -1.799 & 4.638 & 0.016 & 0.219 \\
\hline diff_year_prior_v2svstterr & -49.200 & 38.700 & 0.006 & 2.347 \\
\hline diff_year_prior_v2cseeorgs & -2.795 & 4.327 & 0.026 & 0.288 \\
\hline diff_year_prior_v2csreprss & -3.985 & 4.545 & 0.021 & 0.315 \\
\hline diff_year_prior_v2cscnsult & -3.010 & 3.130 & 0.023 & 0.300 \\
\hline diff_year_prior_v2csprtcpt & -3.479 & 4.308 & 0.029 & 0.276 \\
\hline diff_year_prior_v2csgender & -2.463 & 2.908 & 0.022 & 0.179 \\
\hline diff_year_prior_v2csantimv & -3.801 & 3.993 & -0.009 & 0.353 \\
\hline diff_year_prior_v2csrlgrep & -2.723 & 4.356 & 0.012 & 0.256 \\
\hline diff_year_prior_v2csrlgcon & -2.856 & 3.472 & 0.014 & 0.237 \\
\hline diff_year_prior_v2mecenefm & -4.216 & 4.783 & 0.021 & 0.330 \\
\hline diff_year_prior_v2mecrit & -2.574 & 4.959 & 0.026 & 0.301 \\
\hline diff_year_prior_v2merange & -4.102 & 4.757 & 0.028 & 0.293 \\
\hline diff_year_prior_v2meharjrn & -2.438 & 4.012 & 0.019 & 0.286 \\
\hline diff_year_prior_v2meslfcen & -3.382 & 4.656 & 0.021 & 0.315 \\
\hline diff_year_prior_v2mebias & -3.820 & 4.589 & 0.027 & 0.326 \\
\hline diff_year_prior_v2mecorrpt & -2.923 & 5.011 & 0.020 & 0.272 \\
\hline diff_year_prior_v2pepwrses & -2.940 & 3.437 & 0.001 & 0.224 \\
\hline diff_year_prior_v2pepwrsoc & -2.018 & 3.084 & 0.012 & 0.188 \\
\hline diff_year_prior_v2pepwrgen & -2.046 & 2.760 & 0.028 & 0.185 \\
\hline diff_year_prior_v2pepwrort & -1.049 & 2.210 & 0.019 & 0.136 \\
\hline diff_year_prior_v2peedueq & -2.006 & 2.603 & 0.007 & 0.168 \\
\hline diff_year_prior_v2pehealth & -2.106 & 2.241 & 0.006 & 0.168 \\
\hline diff_year_prior_v2x_accountability & -2.082 & 2.455 & 0.016 & 0.149 \\
\hline diff_year_prior_v2x_veracc & -2.361 & 2.575 & 0.015 & 0.250 \\
\hline diff_year_prior_v2x_diagacc & -1.806 & 2.640 & 0.017 & 0.160 \\
\hline diff_year_prior_v2x_horacc & -2.186 & 2.804 & 0.012 & 0.186 \\
\hline diff_year_prior_v2xex_elecleg & -1 & 1 & 0.004 & 0.151 \\
\hline diff_year_prior_v2x_civlib & -0.589 & 0.676 & 0.005 & 0.046 \\
\hline diff_year_prior_v2x_clphy & -0.698 & 0.735 & 0.004 & 0.055 \\
\hline diff_year_prior_v2x_clpol & -0.715 & 0.828 & 0.005 & 0.058 \\
\hline diff_year_prior_v2x_clpriv & -0.464 & 0.784 & 0.004 & 0.042 \\
\hline diff_year_prior_v2x_corr & -0.644 & 0.486 & 0.001 & 0.035 \\
\hline diff_year_prior_v2x_EDcomp_thick & -0.542 & 0.700 & 0.005 & 0.056 \\
\hline diff_year_prior_v2x_elecreg & -1 & 1 & 0.005 & 0.183 \\
\hline diff_year_prior_v2x_freexp & -0.554 & 0.794 & 0.005 & 0.058 \\
\hline diff_year_prior_v2x_gencl & -0.467 & 0.630 & 0.004 & 0.038 \\
\hline diff_year_prior_v2x_gencs & -0.263 & 0.588 & 0.006 & 0.038 \\
\hline diff_year_prior_v2x_hosabort & -1 & 1 & 0 & 0.050 \\
\hline
\end{tabular}


Table 9: Variables and Descriptive Statistics (cont.)

\begin{tabular}{|c|c|c|c|c|}
\hline Variable & Min & Max & Mean & SD \\
\hline diff_year_prior_v2x_hosinter & -1 & 1 & 0 & 0.128 \\
\hline diff_year_prior_v2x_pubcorr & -0.679 & 0.562 & 0.001 & 0.040 \\
\hline diff_year_prior_v2x_rule & -0.486 & 0.639 & 0.001 & 0.040 \\
\hline diff_year_prior_v2xcl_acjst & -0.594 & 0.688 & 0.003 & 0.045 \\
\hline diff_year_prior_v2xcl_disc & -0.690 & 0.753 & 0.005 & 0.060 \\
\hline diff_year_prior_v2xcl_dmove & -0.446 & 0.827 & 0.003 & 0.044 \\
\hline diff_year_prior_v2xcl_prpty & -0.473 & 0.636 & 0.005 & 0.035 \\
\hline diff_year_prior_v2xcl_slave & -0.511 & 0.708 & 0.002 & 0.035 \\
\hline diff_year_prior_v2xcs_ccsi & -0.524 & 0.767 & 0.005 & 0.057 \\
\hline diff_year_prior_v2xel_elecparl & -1 & 1 & -0.003 & 0.643 \\
\hline diff_year_prior_v2xel_elecpres & -1 & 1 & 0.002 & 0.444 \\
\hline diff_year_prior_v2xex_elecreg & -1 & 1 & 0.009 & 0.157 \\
\hline diff_year_prior_v2xlg_elecreg & -1 & 1 & 0.005 & 0.178 \\
\hline diff_year_prior_v2x_ex_confidence & -1 & 1 & 0.002 & 0.083 \\
\hline diff_year_prior_v2x_ex_direlect & -1 & 1 & 0.006 & 0.158 \\
\hline diff_year_prior_v2x_ex_hereditary & -0.595 & 0.500 & 0 & 0.020 \\
\hline diff_year_prior_v2x_ex_military & -0.732 & 1 & -0.002 & 0.085 \\
\hline diff_year_prior_v2x_ex_party & -0.800 & 0.800 & -0.001 & 0.049 \\
\hline diff_year_prior_v2x_execorr & -0.661 & 0.585 & 0 & 0.046 \\
\hline diff_year_prior_v2x_legabort & -1 & 1 & 0 & 0.061 \\
\hline diff_year_prior_v2xlg_leginter & -1 & 1 & 0 & 0.197 \\
\hline diff_year_prior_v2x_neopat & -0.709 & 0.544 & -0.002 & 0.041 \\
\hline diff_year_prior_v2xnp_client & -0.505 & 0.297 & -0.001 & 0.040 \\
\hline diff_year_prior_v2xnp_pres & -0.837 & 0.670 & -0.003 & 0.050 \\
\hline diff_year_prior_v2xnp_regcorr & -0.652 & 0.464 & 0.001 & 0.044 \\
\hline epr_groups & 1 & 58 & 4.656 & 5.549 \\
\hline epr_elf & 0.013 & 1 & 0.578 & 0.298 \\
\hline epr_excluded_groups_count & 0 & 55 & 2.416 & 4.898 \\
\hline epr_excluded_group_pop & 0 & 0.980 & 0.153 & 0.215 \\
\hline epr_inpower_groups_count & 1 & 15 & 2.240 & 2.138 \\
\hline epr_inpower_groups_pop & 0.020 & 1.044 & 0.774 & 0.255 \\
\hline epr_regaut_groups_count & 0 & 42 & 0.810 & 3.430 \\
\hline epr_regaut_group_pop & 0 & 1 & 0.058 & 0.199 \\
\hline gdp_growth & -83.372 & 453.824 & 3.582 & 10.337 \\
\hline gdp_pc & 77.606 & 117929.820 & 9906.629 & 15970.381 \\
\hline gdp_pc_growth & -83.812 & 444.666 & 1.771 & 10.268 \\
\hline gdp_log & 18.459 & 30.460 & 23.999 & 2.193 \\
\hline gdp_pc_log & 4.352 & 11.678 & 8.093 & 1.552 \\
\hline state_age & 1 & 202 & 74.118 & 61.097 \\
\hline pop & 4.724 & 14.159 & 9.016 & 1.623 \\
\hline
\end{tabular}


Table 9: Variables and Descriptive Statistics (cont.)

\begin{tabular}{lrrrr}
\hline Variable & Min & Max & Mean & SD \\
\hline pt_coup_attempt & 0 & 1 & 0.034 & 0.182 \\
pt_coup_attempt_num & 0 & 4 & 0.038 & 0.216 \\
pt_coup_num & 0 & 2 & 0.018 & 0.137 \\
pt_coup & 0 & 1 & 0.018 & 0.132 \\
pt_failed_coup_attempt_num & 0 & 4 & 0.020 & 0.157 \\
pt_failed_coup_attempt & 0 & 1 & 0.018 & 0.134 \\
pt_coup_total & 0 & 23 & 1.977 & 3.344 \\
pt_coup_attempt_total & 0 & 28 & 3.088 & 4.757 \\
pt_coup_num5yrs & 0 & 5 & 0.100 & 0.365 \\
pt_coup_attempt_num5yrs & 0 & 9 & 0.204 & 0.617 \\
pt_coup_num10yrs & 0 & 6 & 0.218 & 0.614 \\
pt_coup_attempt_num10yrs & 0 & 10 & 0.443 & 1.051 \\
years_since_last_pt_coup & 0 & 202 & 42.533 & 45.415 \\
years_since_last_pt_failed_coup_attempt & 0 & 202 & 49.187 & 54.313 \\
years_since_last_pt_coup_attempt & 0 & 202 & 38.090 & 45.708 \\
internal_confl & 0 & 1 & 0.169 & 0.375 \\
internal_conflmajor & 0 & 1 & 0.051 & 0.220 \\
internal_conflminor & 0 & 1 & 0.130 & 0.337 \\
internal_confl_part & 0 & 1 & 0.278 & 0.448 \\
internal_conflpart_major & 0 & 1 & 0.141 & 0.348 \\
internal_confl_part_minor & 0 & 1 & 0.176 & 0.381 \\
war & 0 & 1 & 0.031 & 0.173 \\
war_major & 0 & 1 & 0.017 & 0.131 \\
war_minor & 0 & 1 & 0.014 & 0.117 \\
any_conflict & 0 & 1 & 0.293 & 0.455 \\
any_conflict_major & 0 & 1 & 0.154 & 0.361 \\
any_conflict_minor & 0 & 1 & 0.183 & 0.387 \\
ext_conf & 0 & 1 & 0.156 & 0.363 \\
ext_conf_major & 0 & 1 & 0.108 & 0.310 \\
ext_conf_minor & 0 & 1 & 0.068 & 0.252 \\
\hline
\end{tabular}

